\title{
Profits and Balance Sheet Developments at U.S. Commercial Banks in 1998
}

Antulio N. Bomfim and William R. Nelson, of the Board's Division of Monetary Affairs, prepared this article. Thomas $C$. Allard assisted in developing, and was responsible for maintaining, the database used in this article. Douglas M. Conover and Adrian R. Sosa provided research assistance.

The performance of the U.S. commercial banking industry remained strong in 1998, but slipped a bit from the remarkable results of recent years. Both the return on assets and the return on equity edged down last year, although they remained high by historical standards (chart 1). While supported by growth in fee income, profitability was damped by a large decline in the rates banks earned on their interest-bearing assets relative to the rates they paid on their liabilities, and also by higher noninterest costs, especially merger and restructuring expenses. Profitability was uneven last year across bank sizes: Whereas the largest and the smallest banks posted lower earnings, the profits of medium-sized banks - which account for almost two-thirds of industry assets-improved once again in 1998. Nevertheless, though these figures attest to the profitability of most banks, the share of bank assets at unprofitable institutions increased 2 percentage points, to 2.6 percent, the highest since $1994 .^{1}$

1. Except where otherwise indicated, data in this article are from the quarterly Reports of Condition and Income (Call Reports) for insured domestic commercial banks and nondeposit trust companies (hereafter, banks). The data consolidate information from foreign and domestic offices and have been adjusted to take account of mergers. For additional information on the adjustments to the data, see the appendix in William B. English and William R. Nelson, "Profits and Balance Sheet Developments at U.S. Commercial Banks in 1997," Federal Reserve Bulletin, vol. 84 (June 1997), p. 408. Size categories, based on assets at the start of each quarter, are as follows: the 10 largest banks, large banks (those ranked 11 through 100 by size), medium-sized banks (those ranked 101 through 1,000 by size), and small banks (those not among the largest 1,000 banks). At the start of the fourth quarter of 1998, the approximate asset size of the banks in those groups were as follows: the 10 largest banks, more than $\$ 71$ billion; large banks, $\$ 6$ billion to $\$ 71$ billion; medium-sized banks, $\$ 309$ million to $\$ 6$ billion; small banks, less than $\$ 309$ million. Many of the data series reported here begin in 1985 because the Call Reports were significantly revised in 1984. Data from before 1985 are taken from Federal Deposit Insurance Corporation, Statistics on Banking (FDIC, 1997). The FDIC data are also available on the World Wide Web (http://www.fdic.gov/databank/sob/). Data shown may not match
1. Measures of commercial bank profitability, 1970-98

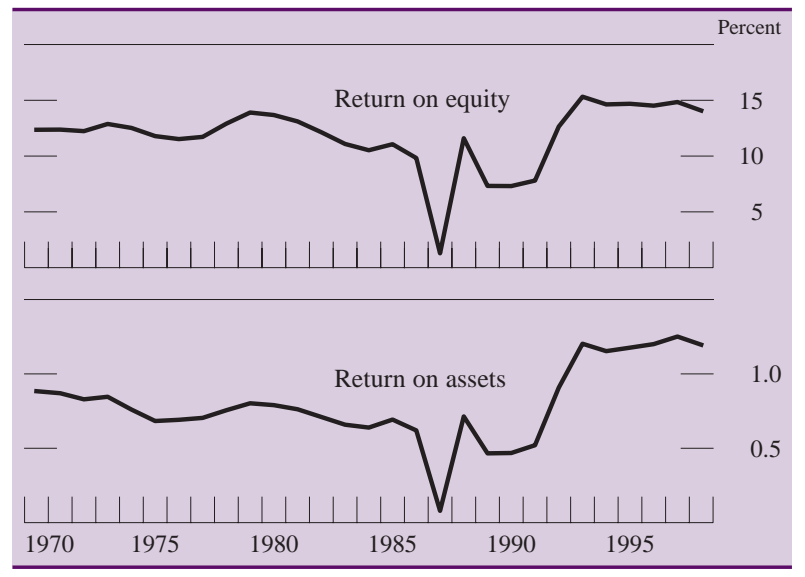

Although, in the third quarter, trading income was sharply curtailed and provisions for loan losses were elevated at the largest banks, the turmoil in financial markets in the second half had little effect on profits last year for the banking industry as a whole. But the late-summer currency devaluation and default in Russia left a discernible imprint on the balance sheets of U.S. commercial banks in 1998: Growth in bank assets was boosted by the financial reintermediation process that characterized much of the second half of last year, with holdings of both loans and securities posting sizable gains.

Bank stocks underperformed broader market indexes in 1998, ending the year about where they began. After having risen strongly in the first half, bank equity prices, particularly those of money center banks, fell sharply in the aftermath of the Russian crisis, but later recovered as conditions abroad calmed and the domestic economic expansion continued. Dividend payments made by banks, including those made to parent holding companies, declined last year, helping bank capital to grow in line with assets. Risk-based capital measures edged down again, but remained high: Nearly 95 percent of bank

data published in earlier years because of revisions and corrections. In the tables, components may not sum to totals because of rounding. 
2. Number of commercial banks and percentage of assets at the largest 100 banks, 1970-98

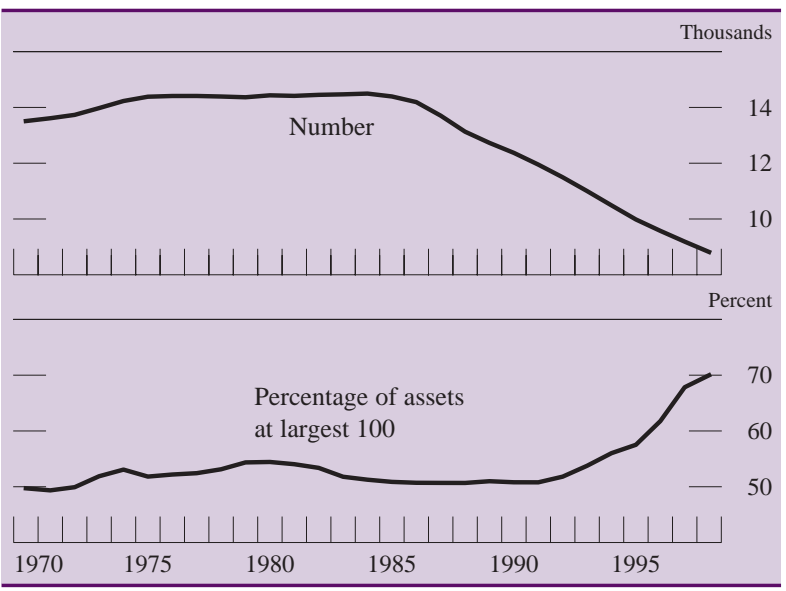

assets were held by institutions classified as "well capitalized" at year-end.

Bank consolidation continued and included some particularly large mergers. As a result, the share of industry assets at the largest 100 banks rose to 70 percent at year-end, up from 673/4 percent a year earlier and around 50 percent in 1985 . The number of commercial banks fell by 371, as the number of newly created banks was more than offset by the 588 banks that ceased to exist (almost entirely because of mergers). At the end of 1998, there were 8,817 commercial banks in the United States, more than one-third fewer than the 14,393 banks that existed in 1985 (chart 2). Banking industry consolidation was also evident in mergers between holding companies, whose numbers declined by 139 last year, to 5,971. The largest 50 holding companies continued to steadily increase their share of industry assets, from 74 percent at the end of 1997 to 76 percent at the end of last year.

\section{BALANCE SHEET DEVELOPMENTS}

Bank assets expanded 81/4 percent last year, versus 91/4 percent in 1997 (table 1). In addition to robust economic conditions throughout the year, turmoil in financial markets in the fall helped sustain the rapid growth of bank credit in 1998. Loans on banks' books benefited the most, increasing almost 9 percent last year after a 51/3 percent rise in 1997. Banks' securities holdings also advanced briskly, rising $81 / 3$ percent, although that was a bit less fast than the increase posted in 1997 . On the liability side, core deposits grew 7 percent, well above the $41 / 2$ percent increase in 1997 but still short of the rapid advance in bank assets. A $91 / 2$ percent expansion in managed liabilities, matched by a similar gain in equity capital, bridged the gap between growth in assets and in core deposits.

\section{Loans to Businesses}

Bank loans to commercial and industrial (C\&I) enterprises expanded almost 13 percent last year, topping even 1997's considerable advance. Nowhere was the influence of last year's two driving forces for bank credit-strong economic fundamentals and skittish financial markets-more evident than in this category of bank loans. For the year as a whole, capital expenditures by nonfinancial corporations expanded rapidly, particularly for below-investment-grade companies, while profits remained near their 1997 level. As a result, the financing gap - the excess of capital expenditures over internally generated fundswidened substantially (chart 3). The borrowing needs of nonfinancial corporations were further elevated by a rapid pace of net equity retirement, which was fueled by corporate mergers and acquisitions and stock buyback programs.

Banks played an especially important role in business financing needs during the fall of last year, when the issuance of corporate securities was severely disrupted and spreads between yields on private debt instruments and on comparable Treasury securities widened appreciably. Indeed, with investors favoring safe and liquid assets, yields on junk bonds rose even as Treasury yields were falling, and the

3. Financing gap at nonfarm nonfinancial corporations, 1990-98

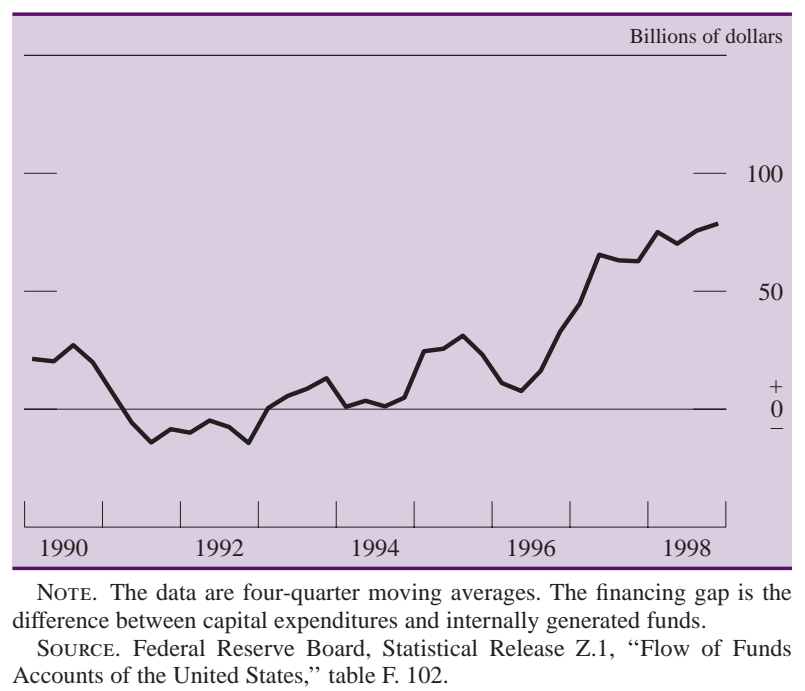


1. Annual rates of growth of balance sheet items, 1989-98

Percent

\begin{tabular}{|c|c|c|c|c|c|c|c|c|c|c|c|}
\hline Item & 1989 & 1990 & 1991 & 1992 & 1993 & 1994 & 1995 & 1996 & 1997 & 1998 & $\begin{array}{c}\text { Mемо: } \\
\text { Dec. } \\
1998 \\
\text { (billions } \\
\text { of } \\
\text { dollars) }\end{array}$ \\
\hline Assets $\ldots \ldots \ldots \ldots \ldots$ & 5.35 & 2.64 & 1.33 & 2.19 & 5.68 & 8.06 & 7.55 & 6.09 & 9.24 & 8.22 & 5,380 \\
\hline $\begin{array}{l}\text { Interest-earning assets } \\
\text { Int........ }\end{array}$ & 5.61 & 2.23 & 1.98 & 2.53 & 6.56 & 5.77 & 7.69 & 5.67 & 8.88 & 8.18 & 4,631 \\
\hline Loans and leases (net) .......... & 6.24 & 2.37 & -2.65 & -1.04 & 6.05 & 9.83 & 10.53 & 8.12 & 8.38 & 8.91 & 3,142 \\
\hline Commercial and industrial & 2.97 & -.67 & -9.10 & -4.10 & .52 & 9.33 & 12.26 & 7.24 & 12.02 & 12.97 & 893 \\
\hline Real estate ................ & 12.69 & 8.79 & 2.73 & 1.94 & 6.13 & 7.90 & 8.33 & 5.44 & 9.30 & 7.98 & 1,335 \\
\hline Booked in domestic offices & 13.02 & 8.55 & 2.90 & 2.57 & 6.17 & 7.64 & 8.48 & 5.50 & 9.53 & 7.96 & 1,304 \\
\hline $\begin{array}{l}\text { One- to four-family } \\
\text { residential }\end{array}$ & 1613 & 1400 & 776 & 753 & 1108 & 1009 & 1006 & 465 & 967 & 6.34 & 758 \\
\hline Other $\ldots \ldots \ldots$ & 10.34 & 3.62 & $\begin{array}{l}1.10 \\
-1.93\end{array}$ & $\begin{array}{r}1.53 \\
-2.86\end{array}$ & $\begin{array}{r}11.08 \\
.22\end{array}$ & $\begin{array}{r}10.09 \\
4.35\end{array}$ & $\begin{array}{r}10.06 \\
6.25\end{array}$ & $\begin{array}{l}4.65 \\
6.75\end{array}$ & $\begin{array}{l}9.61 \\
9.33\end{array}$ & $\begin{array}{r}0.34 \\
10.28\end{array}$ & $\begin{array}{l}158 \\
546\end{array}$ \\
\hline Booked in foreign offices & 2.99 & 16.64 & -2.35 & -17.80 & 4.67 & 18.35 & 2.81 & 3.18 & .34 & 8.79 & 31 \\
\hline Consumer .................... & 6.18 & .38 & -2.55 & -1.66 & 9.06 & 16.01 & 9.50 & 4.90 & -2.18 & 1.03 & 550 \\
\hline Other loans and leases & -.94 & -5.68 & -4.91 & -4.24 & 9.97 & 5.29 & 14.23 & 22.28 & 13.73 & 14.04 & 425 \\
\hline Loan-loss reserves and & & & & & & & & & & & \\
\hline unearned income . & 10.29 & .35 & -3.78 & -4.85 & -5.82 & $\begin{array}{l}-2.22 \\
-2.61\end{array}$ & .25 & -.06 & -.49 & 3.38 & 60 \\
\hline $\begin{array}{l}\text { Securities .................... } \\
\text { Investment account }\end{array}$ & 4.04 & $\begin{array}{l}8.40 \\
8.19\end{array}$ & 14.42 & 11.44 & 8.11 & $\begin{array}{l}-2.01 \\
-1.73\end{array}$ & -1.58 & -1.12 & $\begin{array}{l}8.80 \\
8.68\end{array}$ & $\begin{array}{r}0.34 \\
12.04\end{array}$ & 965 \\
\hline U.S. Treasury …............ & -13.79 & 3.50 & 32.01 & 23.95 & 7.24 & -8.46 & -19.21 & -14.30 & -8.85 & -25.17 & 113 \\
\hline $\begin{array}{l}\text { U.S. government agency and } \\
\text { corporation obligations }\end{array}$ & 33.41 & 24.02 & 15.88 & 12.77 & 9.62 & 87 & 6.43 & 3.61 & 14.20 & 16.98 & 585 \\
\hline Other . . . . . . . . . . . . & -5.35 & -6.70 & -2.56 & -5.20 & 6.09 & 2.49 & 4.20 & 1.82 & 11.21 & 26.93 & 267 \\
\hline Trading account & 20.62 & 11.87 & 38.88 & 21.01 & 51.84 & -9.43 & 18.51 & 14.44 & 9.97 & -13.56 & 125 \\
\hline Other $\ldots \ldots \ldots \ldots \ldots$ & 2.49 & 11.70 & 2.82 & 1.57 & -7.90 & 3.25 & 7.64 & -.90 & 12.81 & 2.35 & 399 \\
\hline Non-interest-earning assets & 3.50 & 5.51 & -3.10 & -.32 & -.86 & 25.65 & 6.61 & 8.87 & 11.48 & 8.47 & 749 \\
\hline Liabilities ..... & 5.43 & 2.37 & 1.01 & 1.35 & 5.12 & 8.31 & 7.17 & 5.95 & 9.13 & 8.09 & 4,926 \\
\hline Core deposits ............ & 5.75 & 7.58 & 5.25 & 5.09 & 1.49 & -.17 & 3.97 & 4.12 & 4.53 & 7.05 & 2,670 \\
\hline 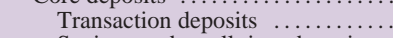 & .93 & 2.43 & 3.38 & 14.62 & 5.47 & -.33 & -3.09 & -3.45 & -4.54 & -1.35 & 747 \\
\hline Savings and small time deposits & 8.71 & 10.51 & 6.24 & .18 & -.85 & -.08 & 8.37 & 8.34 & 9.04 & 10.71 & 1,923 \\
\hline Managed liabilities $^{1} \ldots \ldots \ldots \ldots$ & 5.13 & -6.15 & -6.19 & -6.07 & 12.30 & 17.57 & 10.44 & 9.65 & 13.84 & 9.60 & 1,885 \\
\hline Deposits booked in foreign & & & & & 1506 & 3089 & 5.13 & & & & 572 \\
\hline $\begin{array}{l}\text { offices } \ldots \ldots \ldots \ldots \\
\text { Large time } \ldots \ldots \ldots \ldots \ldots\end{array}$ & $\begin{array}{r}-1.07 \\
5.00\end{array}$ & $\begin{array}{l}-5.88 \\
-5.68\end{array}$ & $\begin{array}{r}3.81 \\
-19.73\end{array}$ & $\begin{array}{r}-5.85 \\
-26.20\end{array}$ & $\begin{array}{r}15.06 \\
-9.21\end{array}$ & $\begin{array}{r}30.89 \\
8.72\end{array}$ & $\begin{array}{r}5.13 \\
19.61\end{array}$ & $\begin{array}{r}4.27 \\
21.16\end{array}$ & $\begin{array}{l}11.13 \\
20.15\end{array}$ & $\begin{array}{l}8.71 \\
9.09\end{array}$ & $\begin{array}{l}5 / 2 \\
413\end{array}$ \\
\hline Subordinated notes and & & & & & & & & & & & \\
\hline debentures $\ldots \ldots \ldots$. & 16.98 & 20.99 & 4.69 & 34.90 & 10.82 & 9.23 & 6.61 & 17.74 & 21.05 & 17.00 & 72 \\
\hline Other managed liabilities & 9.86 & -8.06 & -1.39 & 6.94 & 22.18 & 12.91 & 11.24 & 8.21 & 12.23 & 9.87 & 827 \\
\hline Other $\ldots \ldots \ldots \ldots \ldots$ & 3.29 & 4.43 & -4.18 & -1.02 & 15.30 & 79.17 & 20.46 & 2.60 & 23.79 & 8.11 & 371 \\
\hline Equity capital & 4.18 & 6.64 & 5.98 & 13.75 & 12.58 & 5.24 & 12.00 & 7.72 & 10.46 & 9.62 & 454 \\
\hline Мемо & & & & & & & & & & & \\
\hline Commercial real estate loans ${ }^{2}$ & n.a. & n.a. & -2.58 & -4.03 & -.60 & 4.00 & 6.35 & 7.66 & 10.13 & 11.35 & 554 \\
\hline Mortgage-backed securities .. & 41.00 & 34.39 & 19.27 & 10.37 & 9.66 & -3.12 & .67 & 2.03 & 14.18 & 22.11 & 464 \\
\hline
\end{tabular}

Note. Data are from year-end to year-end

n.a. Not available.

1. Measured as the sum of deposits in foreign offices, large time deposits in domestic offices, federal funds purchased and securities sold under agreements to resell, demand notes issued to the U.S. Treasury, subordinated notes and debentures, and other borrowed money.

2. Measured as the sum of construction and land development loans secured by real estate; real estate loans secured by nonfarm nonresidential properties; real estate loans secured by multifamily residential properties; and loans to finance commercial real estate, construction, and land development activities not secured by real estate.

spread between yields on those bonds and yields on comparable Treasuries roughly doubled between midsummer and mid-fall. The spread between investment-grade corporate bonds and Treasuries also widened substantially during that period, as did that between yields on lower-tier commercial paper and higher-quality paper (charts 4 and 5). Consistent with such inhospitable financial market conditions, respondents to the Federal Reserve's Senior Loan Officer Opinion Survey on Bank Lending Practices (BLPS) in November pointed to shifts from other sources of credit as the primary cause for increased loan demand in the fall. In particular, about three-quarters of the largest domestic and the foreign respondents indicated that substitution from the bond market had intensified loan demand; about half also mentioned

substitution from the commercial paper market. Partly as a result of these substitutions, banks posted further gains in their share of total nonmortgage credit market debt owed by the nonfinancial business sector (chart 6).

The substitutions toward bank financing occurred even though banks, like other lenders, tightened the terms and standards on loans to businesses after the turbulence that hit the financial markets in the second half of the year. Judging from responses to the BLPS, the tightening was especially noticeable for large and medium-sized borrowers and represented the first time that large banks did not ease terms, on net, since 1993 (chart 7). Respondents to the September and November BLPSs cited a reduced tolerance for risk and a less favorable economic environment as rea- 
4. Spreads between yields on corporate bonds and Treasury securities, 1998

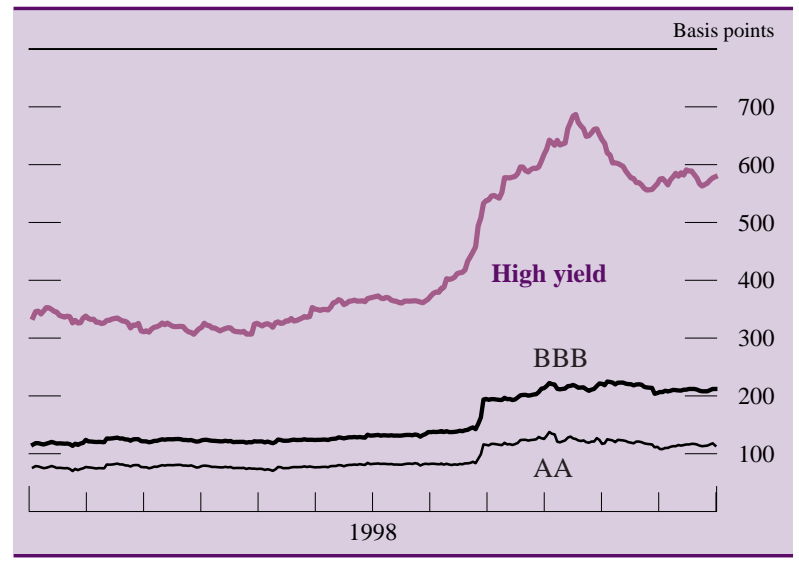

Note. The data are daily. The spread of high-yield bonds compares the yield on the Merrill Lynch Master II index with that on a seven-year Treasury; the other two spreads compare yields on the appropriate Merrill Lynch indexes with that on a ten-year Treasury.

SOURCE. Merrill Lynch; Federal Reserve Board, Statistical Release H.15, "Selected Interest Rates."

sons for the tightening in the latter part of the year. ${ }^{2}$ Data from the Federal Reserve's quarterly Survey of Terms of Business Lending (STBL) also showed a widening of the average spread on business loans in late 1998 (chart 8, upper panels). ${ }^{3}$ While growth in

2. Ordinarily, the BLPS is conducted on a quarterly basis, but the Federal Reserve used its authority to conduct up to six surveys a year to assess the impact of the ongoing financial turbulence on the bank loan market in a special BLPS in mid-September.

3. Although spreads over the federal funds rate widened last fall, rates on loans generally declined, reflecting the effects on market rates of the three easing actions undertaken by the Federal Reserve between September and November.

5. Spread between rates on lower-tier commercial paper and rates on high-quality paper, 1998

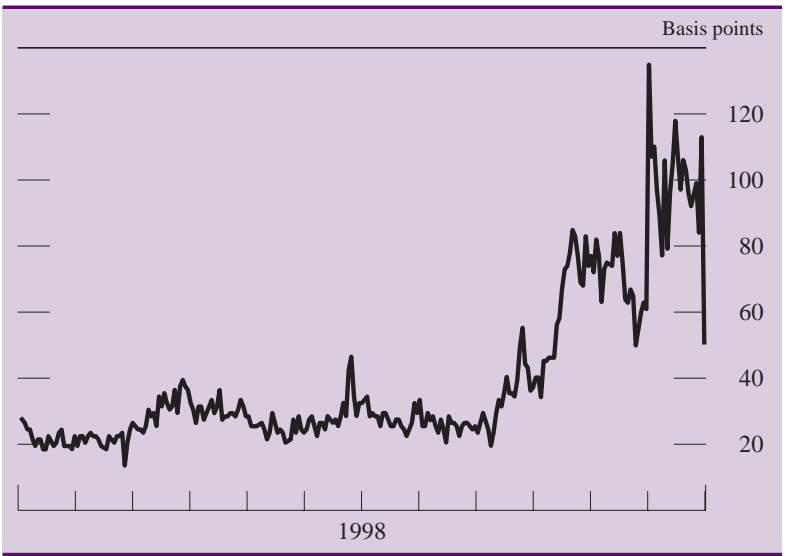

Note. The data are daily. The spread compares the rate on A2/P2-rated, thirty-day commercial paper with that on AA-rated, thirty-day paper.

Source. Federal Reserve Board, Statistical Release, "Commercial Paper."
C\&I loans was strong for banks of all sizes, the widening of spreads was generally applied to larger loans-which are typically made by the bigger banks. These loans were probably taken out by businesses most affected by the financial market turmoil, either because they would normally have raised a significant share of their funds in the capital market, or because they were directly exposed to the Russian crisis and the subsequent deterioration in other emerging-market economies.

Last fall's disruption in the private debt markets highlighted the important role played by loan commitments as a buffer against sudden shifts in financing conditions. Indeed, according to the STBL, spreads on C\&I loans not made under commitment widened much more sharply in late 1998 than did those on other loans, indicating that businesses would have been subject to considerably more financial strain in the absence of such commitments (chart 8, lower panels). As with total C\&I loans, the tightening in conditions on bank loans not made under commitment was most evident for larger loans; spreads on smaller loans widened only slightly last year.

Of course, the existence of loan commitments implies that banks likely made some loans at spreads they considered too narrow under the circumstances that emerged during the second half of last year. Indeed, one-fourth of the banks reported in the January 1999 BLPS that they would tighten terms on more than 20 percent of their outstanding revolving loan commitments if those commitments were maturing and being repriced at the time of the survey.

6. Bank loans as a share of total nonmortgage credit market debt, nonfinancial businesses, 1970-98

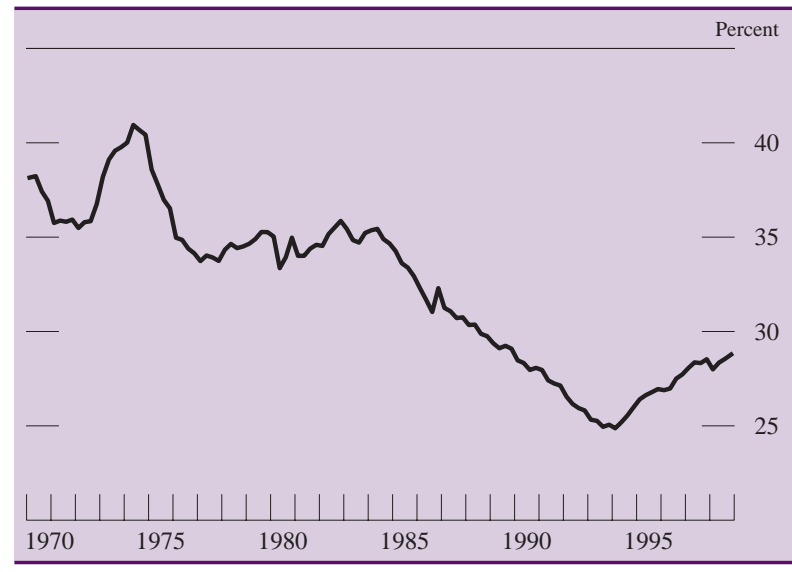

Note. The data are quarterly.

Source. Federal Reserve Board, Statistical Release Z.1, "Flow of Funds Accounts of the United States," table L. 101. 
7. C\&I loan standards and terms, by size of borrower, 1990-99:Q1

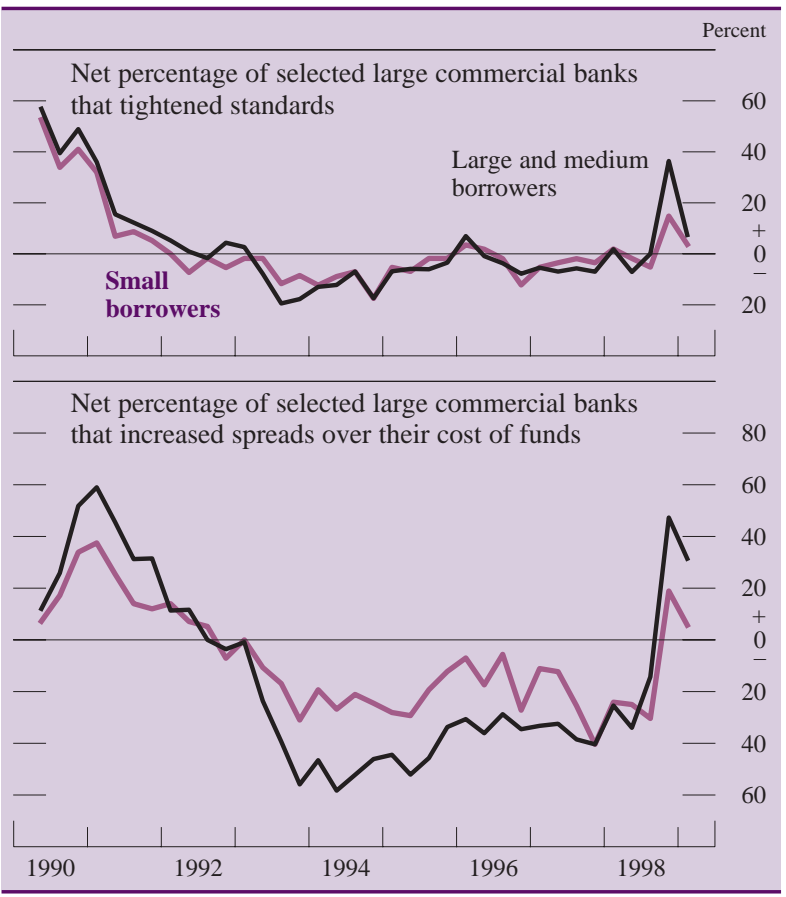

Note. The data are quarterly. Net percentage is the percentage of banks reporting a tightening of standards or an increase in spreads less the percentage reporting an easing or decrease. The definition for firm size suggested for, and generally used by, survey respondents is that medium firms are those with sales of between $\$ 50$ million and $\$ 250$ million.

Source. Federal Reserve Board, Senior Loan Officer Opinion Survey on Bank Lending Practices.

Commercial real estate loans on banks' books accelerated to an $11 \frac{1 / 3}{3}$ percent rise in 1998 , fueled by continuing strong conditions in the property market, especially in the office sector, where vacancy rates fell further and prices continued to rise. In addition, BLPS responses suggest that the demand for bank financing of commercial real estate ventures was enhanced at the end of last year by the turmoil in financial markets. Take, for example, the 35 percent of the domestic survey respondents that reported an increase in demand for commercial real estate loans over the previous three months on the January 1999 BLPS; among them, the most important explanation for the stronger demand was a shift in customer borrowing from lenders having difficulty securitizing commercial mortgages. As with C\&I loans, banks tightened terms and standards on commercial real estate loans in response to market turbulence. According to responses to the November 1998 and January 1999 surveys, the primary reasons for tightening in the second half of the year were disruptions in the market for commercial mortgage-backed securities, a less favorable, or more uncertain, eco-
8. Spread between the C\&I loan rate and the intended federal funds rate, by size of loan and commitment status, 1998-99:Q1

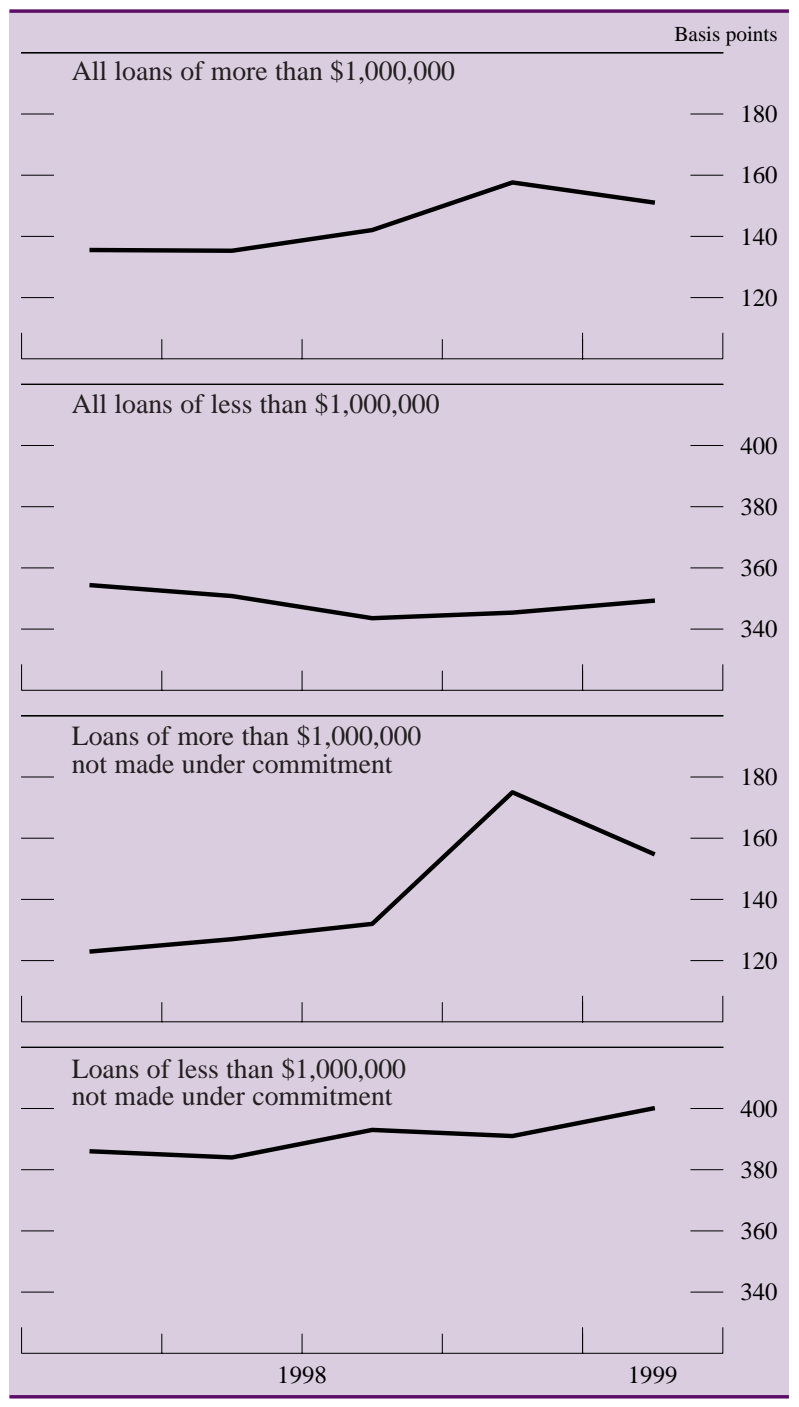

NoTE. The data are quarterly and weighted by loan volume.

Source. Federal Reserve Board, Statistical Release E.2, "Survey of Terms of Business Lending."

nomic outlook, and deepened concern about the reliability of take-out financing.

The strong pace of commercial real estate lending by banks in 1998 extended a five-year uptrend and was most evident among those institutions not included among the top 100 banks. The share of total assets at such banks represented by nonfarm nonresidential real estate loans has been rising steadily, roughly doubling between 1985 and 1998. In contrast, this same share has remained close to constant so far this decade among the largest 100 banks, where commercial real estate loans grew only 6.9 percent last year. Larger banks tend to securitize 
many of their originations as commercial mortgagebacked securities and so hold on their books a smaller share of the loans they make. Increases in securitization in recent years may account for the slow growth of commercial real estate loans on the books of such banks.

\section{Loans to Households}

Consumer loans on banks' books expanded 1 percent last year, following a 21/5 percent decline in 1997. Two main factors helped restrain growth in this category of bank loans, even as consumer spending remained strong throughout the year and a lower proportion of banks reported tightening standards for credit card and other consumer loans than in 1997 (chart 9). On the demand side, households apparently substituted mortgage for consumer debt, as they did in 1997. On the supply side, 1998 was another strong year for consumer loan securitization, although stresses in the financial markets in the fall did cause a temporary disruption to the market for asset-backed securities-which include securities backed by credit card and auto loans. For the year as a whole, the securitized share of bank consumer loans outstanding reached a new high of almost 35 percent at the end of 1998 (chart 10). Including these loans, outstanding consumer loans originated by banks expanded 6 percent last year, compared with a 4 percent rise in 1997. This acceleration reflected a pick-up in the growth of credit card loans originated by banks, which rose

9. Net percentage of selected commercial banks that tightened standards for credit cards and other consumer loans, 1996-99:Q1

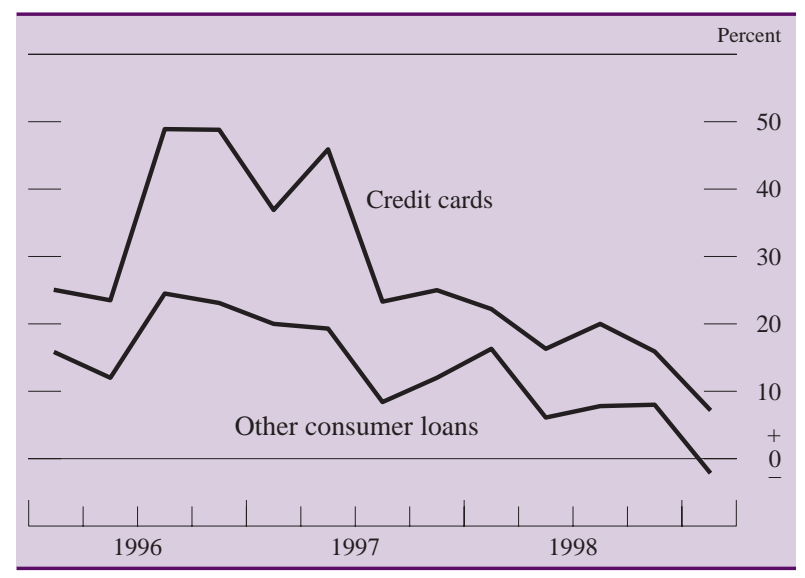

Note. The data are quarterly. Net percentage is the percentage of banks that reported a tightening of standards less the percentage that reported an easing.

Source. Federal Reserve Board, Senior Loan Officer Opinion Survey on Bank Lending Practices.
10. Securitized share of outstanding consumer loans originated by banks, 1988-98

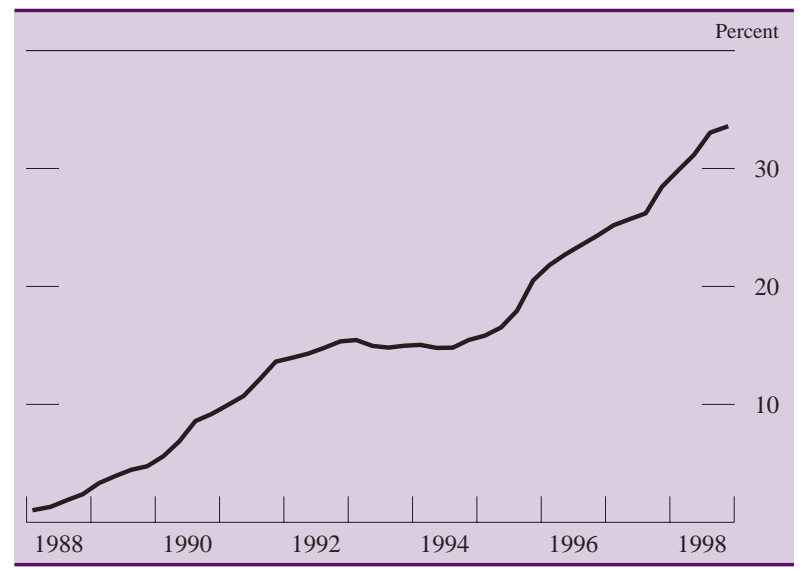

Note. The data are quarterly and seasonally adjusted.

Source. Federal Reserve Board, Statistical Releases H.8, "Assets and Liabilities of Commercial Banks in the United States," and G.19, "Consumer Credit."

$93 / 4$ percent in 1998 , significantly more than the nearly 6 percent rise in 1997 .

Substitutions by households from consumer loans at banks toward home equity loans, which had been particularly prevalent in recent years, were not much in evidence in 1998. Outstanding loans on banks' books made under home equity lines of credit actually fell $1 \frac{1 / 2}{2}$ percent last year, and closed-end residential real estate loans secured by junior liens (second mortgages) increased only 53/4 percent, less than half the average pace of the previous three years. Instead, households appear to have tapped into the accumulated equity in their homes directly in the form of cash-out refinancing and to have used some of the proceeds to pay down or substitute for other debt, including home equity loans. ${ }^{4}$ Indeed, a by-product of the steep decline in yields on Treasury securities during last year's market turmoil was a significant, though not so pronounced, fall in the rates on thirty-year fixed-rate mortgages, which substantially bolstered mortgage refinancing activity last year (chart 11).

The high level of refinancing also acted to lengthen the average remaining maturity of the home mortgages held by banks at year-end, though that lengthening likely reflected, in part, a buildup of loans targeted for securitization by some banks during last year's financial market stress. ${ }^{5}$ Taken together, the

4. According to available estimates, one-third to one-half of homeowners took some cash out when refinancing their mortgages last year.

5. Postponed securitizations probably also contributed to the impressive 14 percent advance in residential real estate loans on banks' books in the fourth quarter. 
11. Average rate on new, fixed-rate thirty-year mortgages and the mortgage refinancing index, 1990-99:Q1

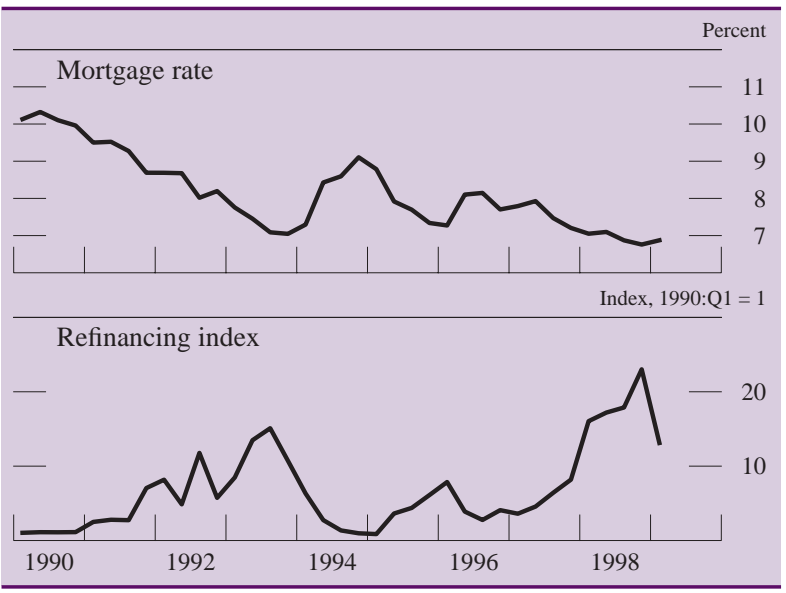

Note. The data are quarterly.

Source. Mortgage rate, from the Federal Home Loan Mortgage Corporation; refinancing index, from the Mortgage Bankers Association.

pickup in refinancing activity and the relative slowing in mortgage securitization during the fall and early winter fostered an expansion in the fraction of mortgages that have fixed rates on banks' books from just over one-half, where it had persisted for several years, to more than two-thirds by year-end. Similarly, the fraction of home mortgages that next reprice or mature further out than five years rose over the year from about one-fourth to about two-fifths.

Despite last year's low mortgage rates, one- to four-family residential loans on banks' books increased only $6 \frac{1}{3}$ percent, well below the $92 / 3$ percent expansion in 1997. Several factors help account for this downshift, even as the residential mortgage market heated up. First, despite the troubles associated with the financial market turmoil, banks continued to securitize a large share of the residential real estate loans they originated in 1998. Indeed, the shift toward fixed-rate mortgages, whose durations considerably exceed that of banks' liabilities, likely increased banks' incentive to securitize those loans. Second, in recent years, banks have faced stiffer competition from nonbank financial institutions in the market for fixed-rate mortgages and thus have benefited relatively less from an increase in demand for these loans. Lastly, as noted above, the expansion in fixed-rate mortgages came partly at the expense of home equity loans.

\section{Securities}

Banks' holdings of securities increased a strong $81 / 3$ percent last year, expanding at about the same rate as total assets. Coupled with the sizable growth in total loans on banks' books, the surge in securities suggests that banks stretched their capital positions further in 1998. Asked about reasons for the rapid buildup in securities during the first quarter of the year, respondents to the May 1998 BLPS cited a willingness to boost leverage to improve return on equity. With growth in bank security holdings strong again late last year, the January 1999 BLPS included additional questions on the subject. Among large banks that reported increased securities holdings in the fourth quarter of 1998, the most important reason offered was that yields on some securities were attractive relative to the costs of funds. Indeed, heightened interest rate volatility and intense risk aversion in the financial markets around that time pushed the yields on mortgage-backed securities to high levels relative to three-month wholesale CD rates (chart 12). Yield spreads on other securities also widened in the fourth quarter relative to funding costs, especially for commercial paper and other corporate securities.

Other reasons offered by banks for expanding their securities holdings in the fourth quarter were, again, a willingness to use more leverage to improve the return on equity and a desire to extend the duration of their securities portfolios. Banks' concerns about the duration of those portfolios were likely related to the market turmoil that dominated the latter part of the year: Unexpectedly low mortgage rates-and the resulting higher prepayment risk-reportedly led to unintended reductions in the duration of banks' portfolios of mortgage-backed securities.

The market turmoil may also have contributed to the fourth-quarter buildup in securities by making it more difficult to place mortgage-backed securities in

12. Spread between the yield on mortgage-backed securities and the rate on the three-month wholesale CD, 1998

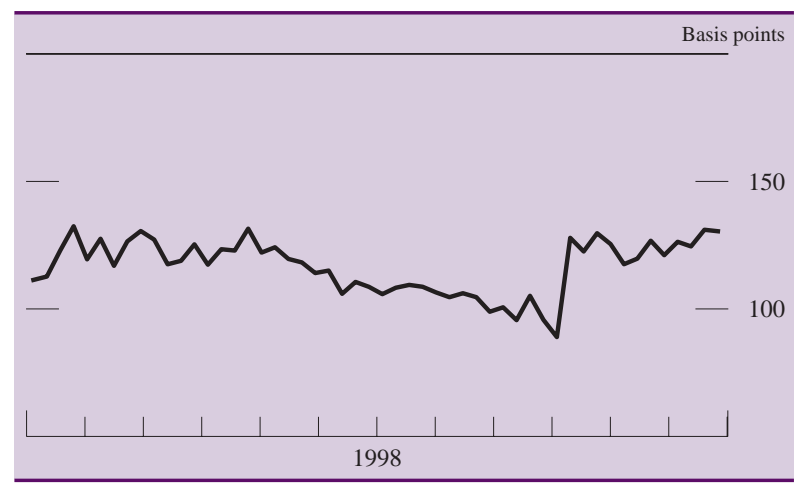

Note. The data are weekly.

Source. For the CD rate, Federal Reserve Board, Statistical Release H.15, "Selected Interest Rates;" for the yield on mortgage-backed securities, Bloomberg L.P. 
the market. In particular, many banks apparently converted refinanced residential loans into mortgagebacked securities because they have a lower capital charge than loans do, but then waited for a more receptive market to sell them. In addition, banks added briskly to their holdings of "other" securities-which include commercial paper and corporate bonds - whose yields, as discussed above, rose relative to other market rates. Other securities also include the many types of instruments backed by loans-including bank-originated loans-other than residential mortgages. As in the mortgage-backed securities market, reluctance by some participants to invest in these securities in the fourth quarter may have contributed to the increase in holdings by banks.

All of the growth in banks' securities portfolios last year occurred in investment accounts, whose holdings advanced 12 percent in 1998, topping even the previous year's strong $82 / 3$ percent expansion. Holdings of securities in trading accounts declined a sizable $13 \frac{1}{1} 2$ percent last year, reflecting a pullback from trading activities in the wake of losses related to the Russian debt default. Over the final two quarters of last year, securities in banks' trading accounts declined nearly $\$ 34$ billion-more than 20 percentwith the runoff occurring entirely in trading assets booked abroad.

\section{Liabilities}

Core deposits at commercial banks grew 7 percent last year, well above the $41 / 2$ percent advance in 1997. ${ }^{6}$ Some of the pickup resulted from a decrease in short-term interest rates spurred by the three monetary policy actions in the fall: As usual, rates on deposits fell more slowly than market rates, trimming the opportunity cost of holding deposits. However, an important additional source of the expansion in core deposits in the latter part of 1998 was likely related to investors' increased preference for safe and liquid assets in light of the turmoil that followed the Russian crisis.

Banks continued to deepen their reliance on managed liabilities, which grew faster than total bank assets for the sixth consecutive year (chart 13). ${ }^{7}$ Though strong, last year's $91 / 2$ percent expansion fell short of the nearly 14 percent rise posted in 1997. The slower growth in 1998 reflected the pickup in core deposits and the deceleration in asset growth.

6. Core deposits are transaction accounts, savings accounts (including MMDAs), and small time deposits.

7. Managed liabilities are defined in table 1.
13. Annual growth of assets and change in the ratio of managed liabilities to assets, 1986-98

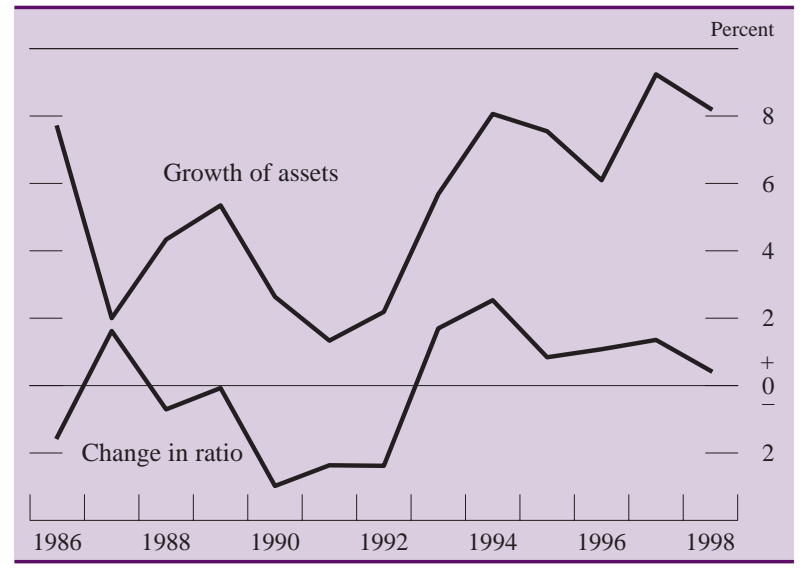

Note. The data are from year-end to year-end.

Subordinated notes and debentures, which expanded 17 percent, posted the strongest growth among major categories of managed liabilities.

\section{Capital}

Bank equity grew $91 / 2$ percent last year, maintaining the share of assets funded with capital essentially at its 1997 level of $81 \frac{1}{2}$ percent. Capital for regulatory purposes also increased about in line with assets, and the leverage ratio moved sideways. About half of the growth in bank equity was attributable to the portion of income retained by banks. Indeed, as discussed below, the dollar amount of dividends paid in 1998 declined for the first time since 1992, suggesting that rapid growth in both loans and securities may have resulted in some capital pressures last year. Those same pressures probably were related to the substantial rise in new capital provided by parent holding companies last year, as they evidently felt the need to bolster the capital positions of their banks. New capital accounted for about a quarter of the growth in bank equity, and the remainder was owed in large part to the excess of banks' issuance of equity related to acquisitions over the value of the shares of banks retired in mergers.

Though the ratio of capital to assets was unchanged, risk-based capital measures (total and tier 1) edged down again in 1998, after several consecutive annual increases through 1996 (chart 14). ${ }^{8}$ Despite

8. The tier 1 ratio is the ratio of tier 1 capital to risk-weighted assets, and the total ratio is the ratio of the sum of tier 1 and tier 2 capital to risk-weighted assets. Tier 1 capital consists mainly of common equity (excluding intangible assets such as goodwill and 
14. Regulatory capital ratios and the share of industry assets at well-capitalized banks, 1991-98

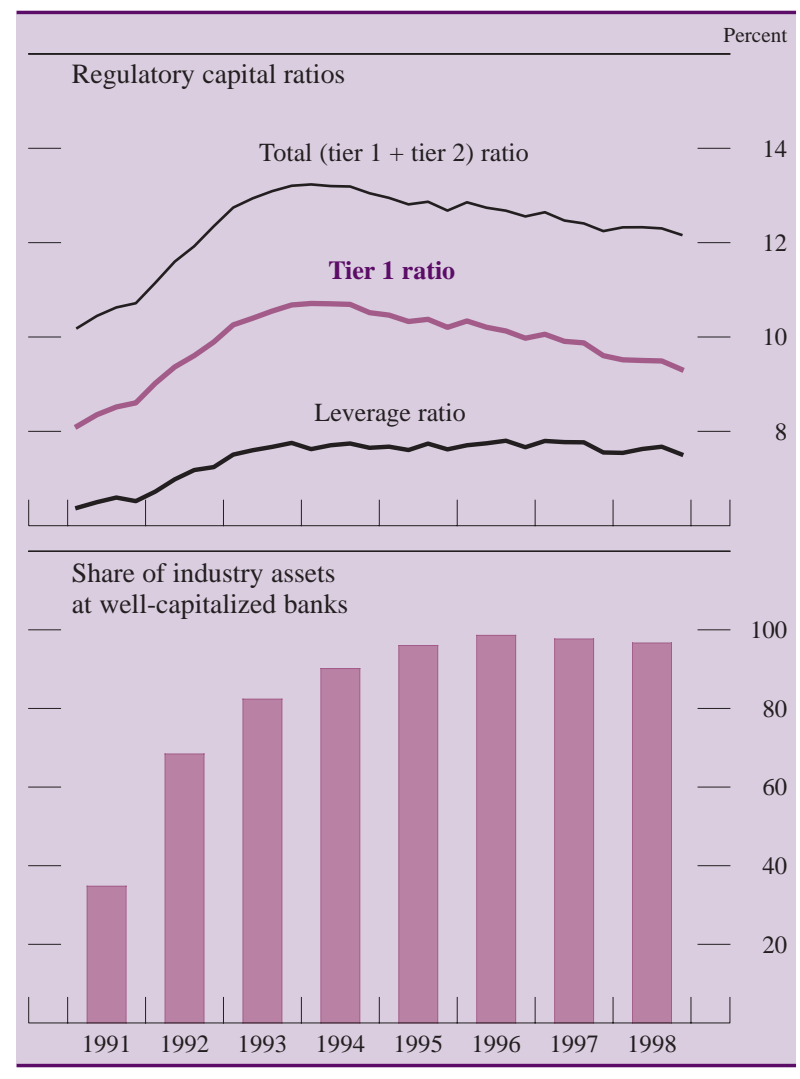

Note. The data on regulatory capital ratios are quarterly. For the definition of capital ratios, see text note 8 .

their decline last year, regulatory capital ratios remained high, and nearly 95 percent of bank assets were at well-capitalized banks at the end of 1998. Nevertheless, the average margin by which these banks remained well capitalized shrank further last year, a signal that banks may become more concerned about their overall capital positions. ${ }^{9}$

excluding net unrealized gains on investment account securities classified as available for sale) and certain perpetual preferred stock. Tier 2 capital consists primarily of subordinated debt, preferred stock not included in tier 1, and loan-loss reserves. Risk-weighted assets are calculated by multiplying the amount of assets and the creditequivalent amount of off-balance-sheet items (an estimate of the potential credit exposure posed by the item) by the risk weight for each category, where the risk weights rise from zero to 1 as the credit risk of the assets increases. The leverage ratio is the ratio of tier 1 capital to average tangible assets. Tangible assets are equal to total assets less assets excluded from common equity in the calculation of tier 1 capital.

9. The average margin by which banks remained well capitalized was computed as follows. First, we looked at the leverage, tier 1, and total capital ratios of each well-capitalized bank and defined the institution's tightest capital ratio as that one closest to the regulatory standard for being "well capitalized." We then defined the bank's margin as the percentage-point difference between its tightest capital

\section{TRENDS IN PROFITABILITY}

The net income of U.S. commercial banks increased 4 percent to $\$ 61 \frac{1 / 2}{2}$ billion in 1998 . The industry's return on assets fell 5 basis points to 1.20 percent (table 2), and return on equity declined $3 / 4$ percentage point to 14 percent-below the elevated range it has occupied since 1993, although still high relative to longer-term historical norms. The prices of bank stocks, particularly those of money center banks, rose strongly in the first half of the year, as concerns ebbed that the troubles that had emerged in Asia in the preceding year would slow the U.S. economy or cause significant trading and loan losses at banks with Asian exposures (chart 15). In the summer, however, worries over prospects for emerging-market economies arose, and fresh turbulence in financial markets sparked by the Russian default resulted in sharply lower trading income and higher loan losses at some large banking companies. A sharp decline in bank stocks ensued. Toward year-end, as markets calmed and investors' concerns about trading exposures eased, bank stock prices recovered, ending the year about where they began, although down relative to most broad stock indexes.

Though investor attention was focused on the trading and foreign-related losses of a few large banks in the third quarter, industry profitability for the year as a whole was more seriously affected by a narrowing of the net interest margin and by a rise in noninterest expense, including merger and restructuring charges. These influences were only partly offset by higher noninterest income, which reflected a continuation of a decade-long rise in fee-generating activities, including the funding by banks of assets through securitization rather than on their balance sheets.

As a result of the decline in profitability, as well as the capital pressures discussed above, the dollar amount of dividends, which are paid primarily to parent holding companies, declined more than 3 percent last year (a decline of 10 basis points as a percentage of assets); this was the first annual reduction in the dollar amount of dividends since 1992. Nonetheless, the fifty largest bank holding companies increased dividends paid to stockholders $\$ 2.6$ billion, to $\$ 19.6$ billion, last year. However, those holding companies more than offset the rise in dividends by reducing net stock repurchases $\$ 17.3$ billion, to

ratio and the corresponding regulatory standard. The average margin among all well-capitalized banks - the measure we refer to in the text - is the weighted average of all the individual margins, in which the weights are each bank's share of the total assets of well-capitalized banks. 
2. Selected income and expense items as a proportion of assets, 1992-98 Percent

\begin{tabular}{|c|c|c|c|c|c|c|c|}
\hline Item & 1992 & 1993 & 1994 & 1995 & 1996 & 1997 & 1998 \\
\hline Net interest income & 3.89 & 3.90 & 3.78 & 3.72 & 3.73 & 3.67 & 3.52 \\
\hline Noninterest income & 1.95 & 2.13 & 2.00 & 2.02 & 2.18 & 2.23 & 2.40 \\
\hline Noninterest expense & 3.86 & 3.94 & 3.75 & 3.64 & 3.71 & 3.61 & 3.77 \\
\hline Loss provisioning & .78 & .47 & .28 & .30 & .37 & .41 & .41 \\
\hline Realized gains on investment account securities & .11 & .09 & -.01 & .01 & .03 & .04 & .06 \\
\hline Income before taxes and extraordinary items & 1.32 & 1.70 & 1.73 & 1.81 & 1.85 & 1.93 & 1.81 \\
\hline Taxes and extraordinary items . & .41 & .50 & .58 & .63 & .65 & .67 & .61 \\
\hline Net income (return on assets) & .91 & 1.20 & 1.15 & 1.18 & 1.20 & 1.25 & 1.20 \\
\hline Dividends & .41 & .62 & .73 & .75 & .90 & .90 & .80 \\
\hline Retained income $\ldots \ldots \ldots$ & .49 & .58 & .42 & .43 & .30 & .35 & .39 \\
\hline
\end{tabular}

$\$ 8.9$ billion. The sum of dividends and net stock repurchases at the top fifty holding companies was one-third lower in 1998 than in 1997.

Industry performance differed markedly by bank size in 1998. The return on equity of the top 10 banks, which absorbed the bulk of the trading and foreign-related losses as well as the merger and restructuring charges, was the hardest hit, falling $23 / 4$ percentage points to $10 \frac{1}{2}$ percent, its lowest level since 1991. At the other end of the spectrum, earnings of the smallest banks-those not in the top 1,000 - were also below recent norms last year. Net interest income makes up the largest share of revenue for these banks, and smaller net interest margins contributed to a decline of $1 / 2$ percentage point in their return on equity to just over 12 percent. By contrast, medium-sized banks, for which noninterest income is a more significant share of revenue and which generally do not have large trading or foreign

15. Indexes of bank holding company stock prices and the S\&P 500, January 7, 1998-March 31, 1999

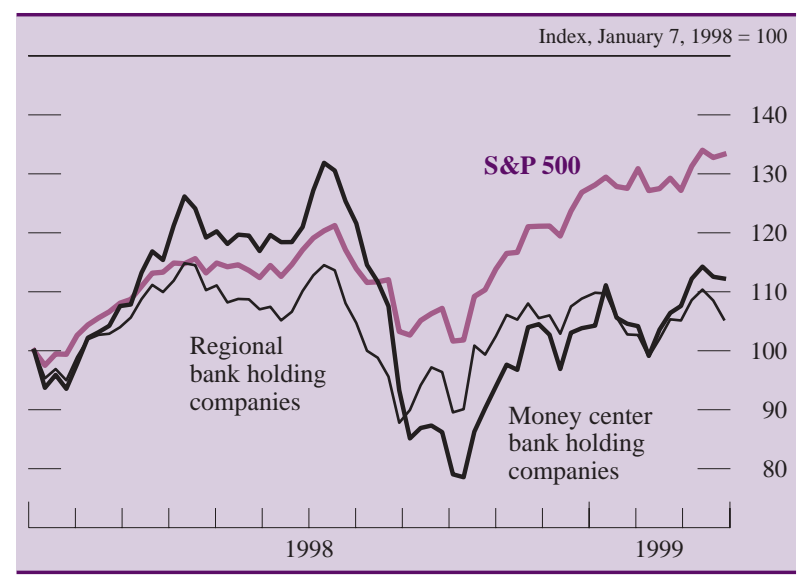

Note. The data are weekly. The holding company indexes are for seven money center companies and forty-two regional companies as defined by Dow Jones.

Source. Dow Jones and Standard and Poor's. operations, had another record year in 1998. Banks in the top 100 but not in the top 10, and those in the top 1,000 but not in the top 100 , generated returns on equity of $171 / 2$ percent and $15 \frac{1}{2}$ percent, respectively—in both cases record highs.

\section{Interest Income and Expense}

Net interest income as a percentage of average assets declined 15 basis points last year, reflecting a similar decline in banks' net interest margin (net interest income as a percentage of average interest-earning assets), which fell to a level not seen in seven years (chart 16). Three factors contributed to the decline in the net interest margin: A shift in bank assets away from relatively high-yielding assets, a shift in bank sources of funds toward relatively expensive liabilities, and, controlling for these shifts, a decline in rates earned on bank assets relative to rates paid on bank liabilities.

About one-third of the narrowing of the net interest margin resulted from the shift in the composition of bank assets last year away from consumer loans. Consumer loan yields are higher, on average, than those on other bank assets, in part as compensation for the higher expense of servicing these loans, and also because of their higher loss rates. As noted earlier, some of the slow growth in consumer loans on banks' books last year resulted from the funding of these loans off bank balance sheets through securitization, which shifted some of the associated net revenue generated out of net interest income and into noninterest income. In addition, a few basis points of the decline in the net interest margin stemmed from banks' increased reliance on managed liabilities, which generally pay higher yields than core deposits.

The remaining two-thirds of the narrowing of the net interest margin resulted from a decline in the yields on bank assets relative to bank liabilities after 
16. Net interest margin, investment-account securities as a share of interest-earning assets, and consumer loans as a share of total loans, 1985-98

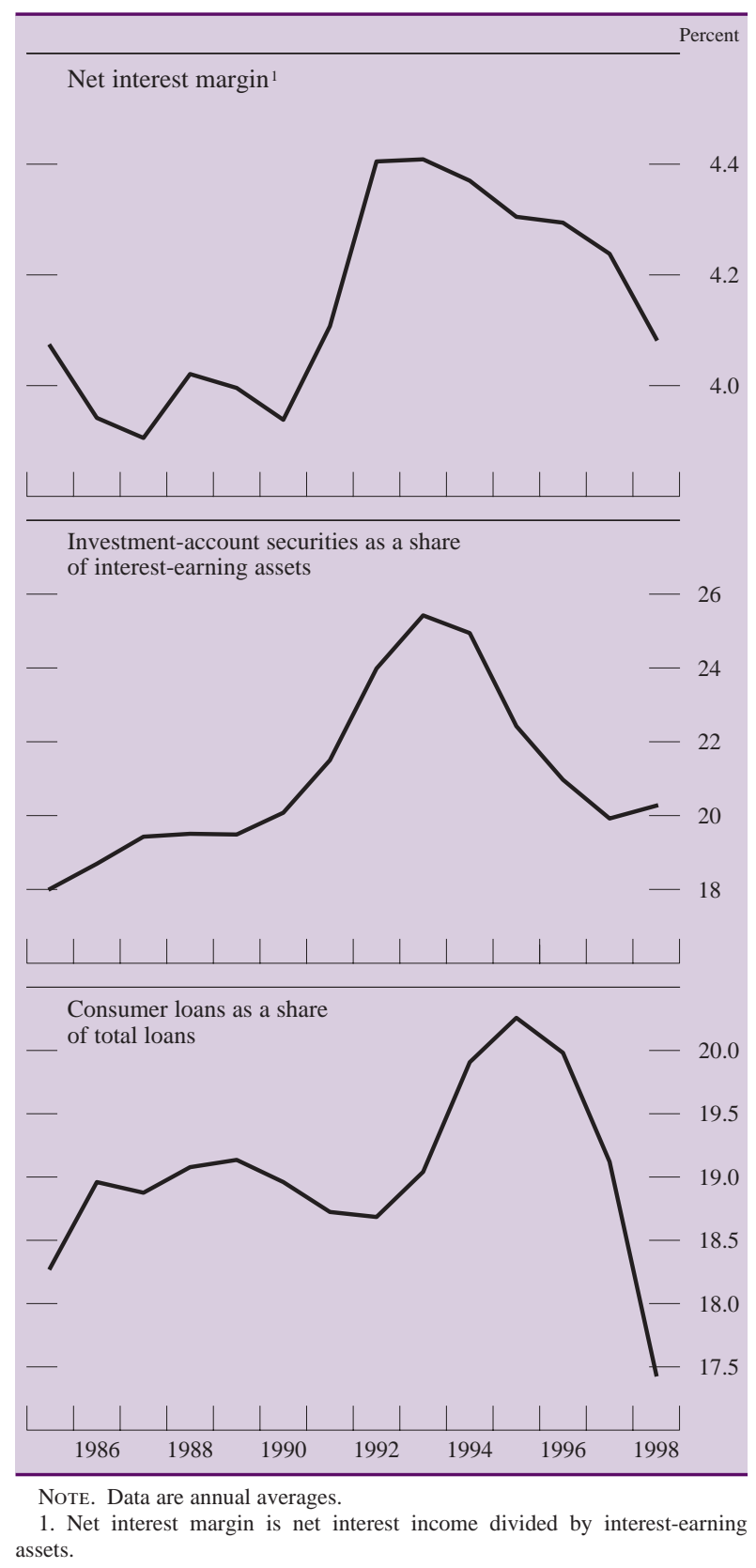

controlling for shifts in composition. Yields on bank assets shrank in part because for most of the year, banks continued to compete vigorously for business loans, and as discussed above, the average spread on these loans over the intended federal funds rate, measured by the Survey of Terms of Business Lending, remained quite narrow through the early part of the third quarter. It widened in the fourth quarter, but because the survey measures rates on newly extended loans, most of any resulting gain in bank profits will appear only gradually over several quarters. A decline in the average yield on real estate loans, no doubt owing in part to the wave of refinancings last year, also contributed to the decline in the average yield on bank assets.

Developments that placed upward pressure on interest expense also acted to narrow the net interest margin. In the fall, the spread between rates on the managed liabilities of banks and risk-free rates widened sharply, as these institutions were seen by investors as vulnerable to losses abroad and a slowing in the domestic economy. ${ }^{10}$ Furthermore, rates on core deposits, which tend to adjust gradually in any case, were especially slow to match the decline in market rates in the fall, because banks needed to fund the rapid growth in assets at that time.

The shrinkage in the net interest margin last year nearly completes the reversal of the sharp expansion in the margin in 1991 and 1992. That expansion was largely the result of two factors. First, it was a reaction to the compression of margins in the late 1980s by competition among banks for loans and funding sources as well as by the elevated rates that some troubled banks and thrift institutions were paying for funds. Second, a number of banks may not have had the capital levels they needed to meet risk-based capital rules phased in between 1990 and 1992. With bank equity prices depressed at that time, capital was expensive to raise, and so these banks were under pressure to limit balance sheet expansion and push up profits. Consequently, they bid for deposits and made loans less aggressively, causing a widening of spreads between loan and deposit rates. Moreover, competitive pressures on margins also may have eased as troubled institutions were recapitalized or closed.

Since 1993, the banking industry has grown rapidly, and the forces that widened the margin have been unwound, largely because of banks' increasingly competitive stance in loan markets and greater reliance on managed liabilities. Several factors had limited the narrowing in the margin between 1994 and 1996, including a shift in bank assets toward loans, particularly consumer loans; relatively low rates paid on deposits compared with market rates; and a greater reliance on capital, the returns on which are not included as an interest expense. However, for the last two years these supporting forces have generally not been present, or have been reversed. As a result, the net interest margin has narrowed faster.

10. In the fourth quarter, banks still found it advantageous to invest in assets, particularly some types of securities, suggesting that expected returns on these assets rose by even more than the increase in banks' marginal cost of funds. 


\section{Noninterest Income}

Noninterest income as a percentage of assets rose 18 basis points last year, more than matching the decline in net interest income. Noninterest income also increased as a share of revenue last year, continuing a decade-long trend (chart 17). The increase was concentrated in the "other fee income" component of noninterest income, which includes, among other items, credit card fees, mortgage servicing fees, fees from the sale and servicing of mutual funds and annuities, ATM surcharges, and fee income from securitized loans; it excludes deposit fees, which edged down 1 basis point as a percentage of assets last year. Although no finer detail is available on other fee income, the increase last year probably reflected, in part, the high level of mortgage refinancing, for which banks collect processing fees, and the rapid growth in bank loans that are securitized, earnings on which are generally booked in this component.

17. Noninterest income and its components as a share of total revenue, 1985-98

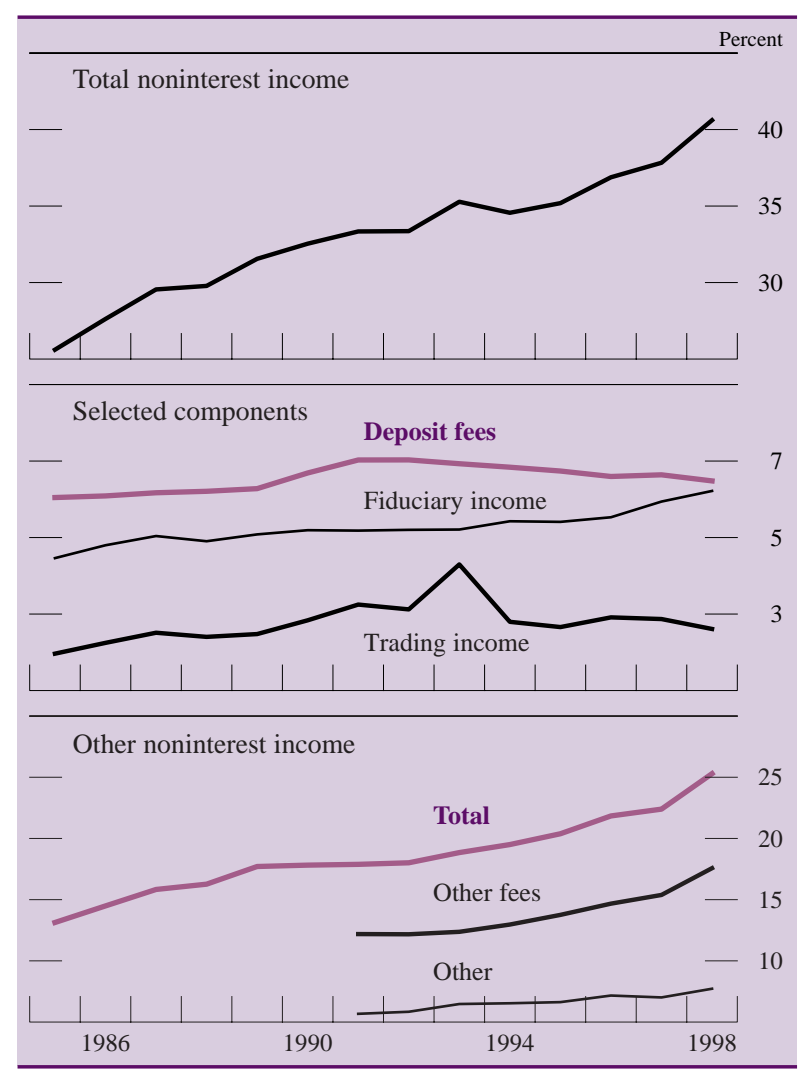

NotE. Components of "other noninterest income" were first included in the March 1991 Call Reports.
The rise in other fee income was particularly apparent at banks that specialize in credit card lending. ${ }^{11}$ These credit card banks, defined here as those banks among the largest 1,000 by assets for which credit card loans constitute more than half of assets, earned a return on equity of $291 / 2$ percent in 1998 ; this was sharply more than the $173 / 4$ percent in 1997 , and only slightly below the returns on equity earned by these banks in 1993 and 1994, before the significant worsening of the performance of credit card loans in 1995. Credit card banks earn nearly half of their revenue as other fee income, compared with $141 \frac{1}{2}$ percent of revenue for other banks, and they account for a quarter of the other fee income earned by all commercial banks. Other fee income makes up such a large share of revenue at these banks because more than three-fourths of their on-balance-sheet assets are credit card loans, and off-balance-sheet credit card loans at these banks exceed their on-balance-sheet assets.

The increase in noninterest income was due also to a rise in the nonfee component of "other noninterest income." Among the items in this component are income from professional services, including those provided for holding company affiliates; gains on the sale of assets other than securities, including loans and bank branches; and income from venture capital activities. Industry consolidation may have contributed to the growth in this component, in part because of the resulting rise in the provision of specialized services within holding companies (fees on which do not increase the income of the holding company as a whole), and in part because of the sale of assets in the course of mergers and reorganizations. Some banks book gains on proprietary investments in equities resulting from the venture capital activities of their small business investment company subsidiaries in this component, so the rise in stock prices over recent years has probably contributed to its growth as well.

The bull market for equities, and the high volume of financial transactions, has likely also benefited fiduciary income, which rose 2 basis points as a percentage of assets in 1998. Fiduciary income includes earnings on services rendered by banks' trust departments and by any consolidated subsidiaries acting in a fiduciary capacity.

The trading income component of noninterest income declined 2 basis points last year as a percentage of assets. During the first half of the year, trading

11. For more information on credit card banks, see William R. Nelson and Ann L. Owen, "Profits and Balance Sheet Developments at U.S. Commercial Banks in 1996," Federal Reserve Bulletin, vol. 83 (June 1997), pp. 476-77. 
3. Trading revenue at all U.S. banks, by type of exposure, 1995-98 Millions of dollars

\begin{tabular}{r|r|r|c|c}
\hline \multicolumn{1}{c|}{ Year } & Total & $\begin{array}{c}\text { Interest } \\
\text { rate }\end{array}$ & $\begin{array}{c}\text { Foreign } \\
\text { exchange }\end{array}$ & $\begin{array}{c}\text { Equity and } \\
\text { other }\end{array}$ \\
\hline $1995 \ldots \ldots$ & 6,337 & 3,012 & 2,491 & 635 \\
$1996 \ldots \ldots$ & 7,526 & 4,112 & 2,689 & 725 \\
$1997 \ldots \ldots$. & 8,020 & 3,995 & 3,951 & 72 \\
$1998 \ldots \ldots$ & 7,678 & 2,469 & 4,715 & 493 \\
Q1 $\ldots \ldots .$. & 2,652 & 1,068 & 1,320 & 264 \\
Q2 $\ldots \ldots$. & 2,531 & 942 & 1,342 & 247 \\
Q3 $\ldots \ldots$. & 543 & -101 & 875 & -232 \\
Q4 $\ldots \ldots$. & 1,952 & 560 & 1,178 & 214 \\
\hline
\end{tabular}

revenues, particularly those earned on exchange rate exposures, were robust (table 3). However, in the third quarter, following the pronounced widening of liquidity and risk spreads, trading income declined precipitously and several large banks posted trading losses. The losses, reportedly, were of three general kinds: First, the sharp decline in the value of certain securities, including some foreign-related assets such as Brady bonds, caused losses at those banks holding such securities in their trading accounts on an unhedged basis. Second, in some cases U.S. banks had hedged their holdings by taking two offsetting positions. When some Russian counterparties defaulted, the U.S. banks were left with substantial losses on the contracts that had been hedged by the contracts with those Russian counterparties. ${ }^{12}$ Lastly, in other cases, the deteriorating financial condition of counterparties in emerging-market economies, including Asia and Latin America, led some banks to write down the value of trading assets to reflect widening credit-risk spreads. Trading income subsequently recovered in the fourth quarter and, for the year as a whole, was only slightly below its level in 1997.

Profits were supported somewhat last year by realized gains on investment account securities, which increased 40 percent to $\$ 3$ billion. The realized gains were strongest in the fourth quarter and reflected, in part, sales of Treasury securities that had risen in value in the fall.

12. When bank counterparties in derivatives transactions default, the resulting obligation to the bank is either first recorded as a loan and then charged off, or is recorded as a trading loss. Since 1996, banks have reported credit losses on derivatives transactions on the Call Report, although they have not indicated whether the losses were booked as a charge-off or as a debit to trading revenue. These losses totaled \$781 million last year, up from \$120 million in 1997 and $\$ 37$ million in 1996.

\section{Noninterest Expense}

Bank profitability was damped last year by a sharp rise in noninterest expense, as a percentage of both assets and revenue (chart 18). The rise was largest in the broad "other noninterest expense" category, which accounts for almost half of noninterest expense. Some of it was attributable to merger and restructuring charges and to an increase in data processing services, in part from efforts to prepare computer systems for the century date change. ${ }^{13}$

Noninterest expense was also elevated by a rise in wage and occupancy costs, both of which increased about 10 percent last year, in each case the most rapid growth in more than a decade. Labor costs rose so fast in part because employment, which had declined 4 percent between 1985 and 1995, advanced 41/4 percent last year alone, following 2 percent growth in

13. The five largest bank holding companies, which together account for one-third of commercial bank assets, reported aggregate costs of preparing for the century date change of approximately $\$ 1.3$ billion in 1998. By comparison, other noninterest expense of commercial banks rose $\$ 13.6$ billion in 1998 . However, not all of the preparedness costs reported by the these bank holding companies would be booked at their commercial bank subsidiaries.

18. Noninterest expense and its components as a percentage of total revenue, 1985-98

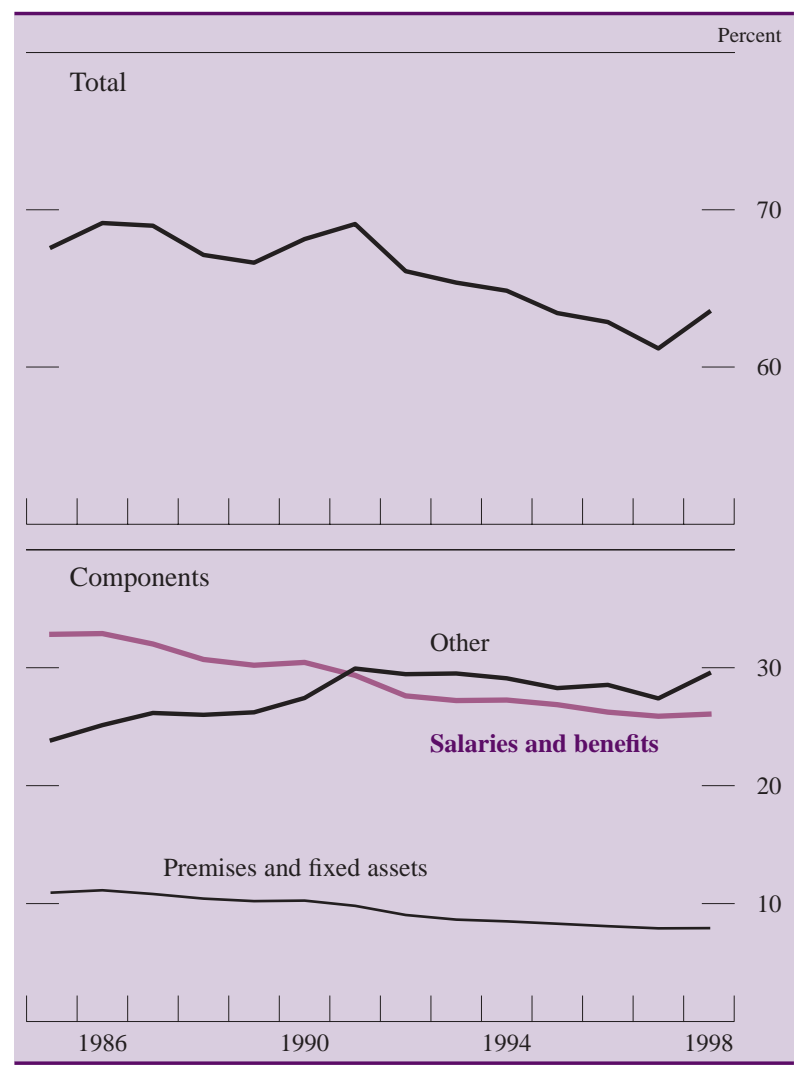


1997. Employment growth was particularly robust in the fourth quarter, and was relatively faster at those banks that posted more rapid growth in home mortgages, suggesting employment growth may have been lifted by the mortgage refinancing boom. Despite the rise in employment, revenue per employee increased $41 / 2$ percent last year, although employment costs per employee rose $5 \frac{1}{2}$ percent.

The rise in occupancy costs stemmed, in part, from a small increase in the number of bank offices, but more importantly from a $63 / 4$ percent rise in real occupancy cost per office, which had fallen 3 percent between 1985 and 1997. The abundant supply of office space had resulted in a decline in the rents on, and prices of, office buildings nationwide in the early 1990s, helping to restrain banks' occupancy costs, but office rents and prices rose sharply in 1997 and 1998.

\section{Loan Provisioning and Loan Performance}

Bank profits continue to be supported by the good overall performance of loans. Although provisions for loan and lease losses edged up last year as a percentage of loans, tracking the slight rise in net
19. Loss provisioning and net charge-offs as a percentage of loans, 1976-98

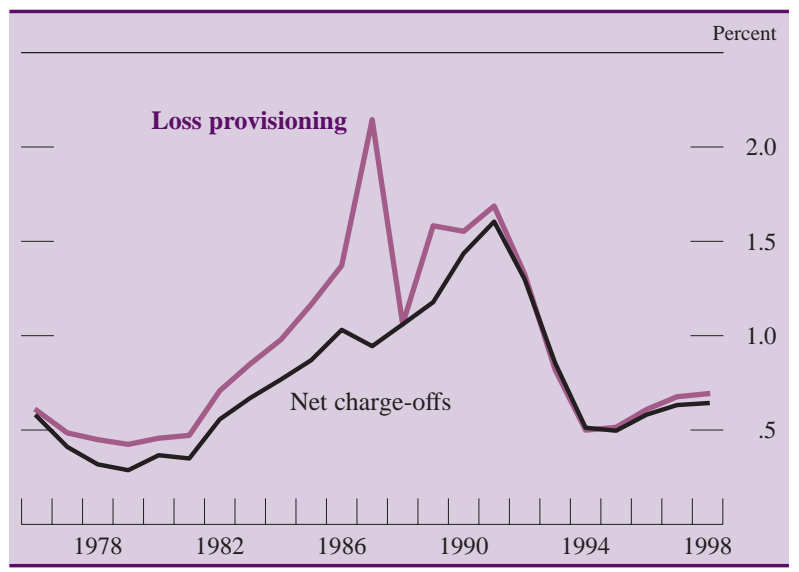

Note. Net charge-offs are charge-offs net of recoveries.

charge-offs, both provisions and charge-offs remained very low in 1998 (chart 19).

The performance of specific types of loans also changed little last year. The delinquency rate on commercial mortgages fell a bit further from the already low levels posted in 1997, reflecting the strong market for office and commercial space

20. Delinquency and charge-off rates, by type of loan, 1991-98

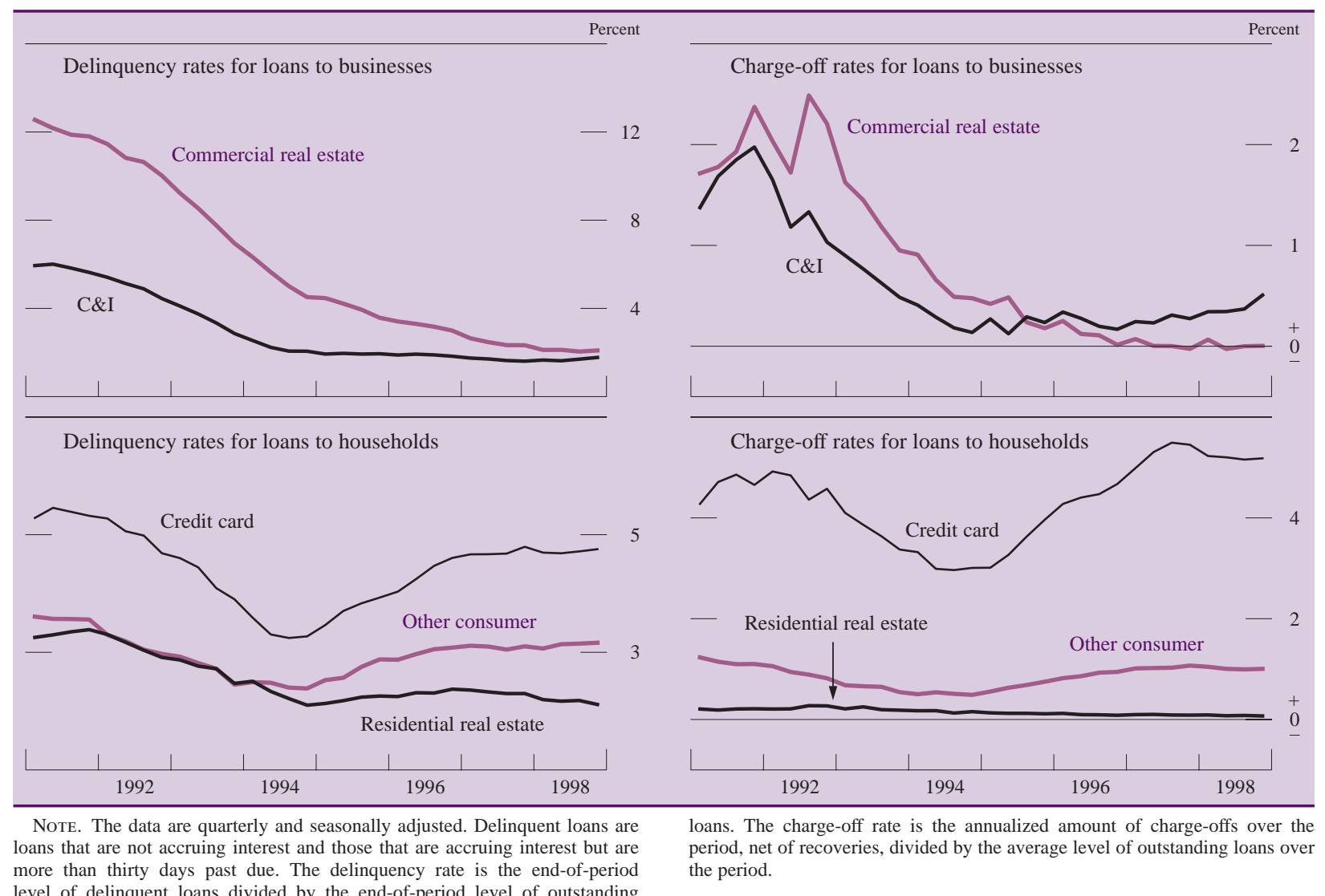


21. Charge-off rates on C\&I loans, by location of borrower, 1992-98

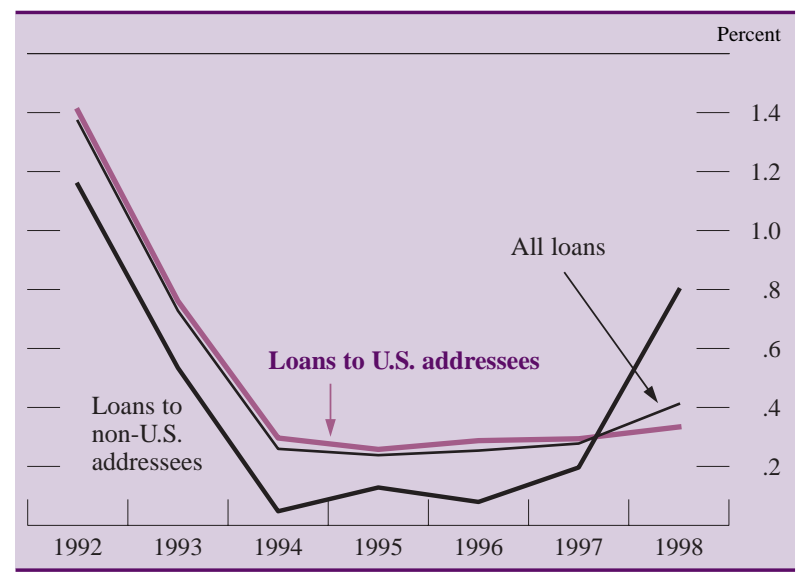

(chart 20). The net charge-off rate on these loans remained near zero. Delinquency and charge-off rates on commercial and industrial loans rose a little, though they too remained low. Most of the moderate upward trend in charge-off rates on C\&I loans for the past two years reflects an increase in loss rates on loans booked abroad, probably to some extent because of difficulties in a number of emergingmarket economies (chart 21). The good performance of C\&I loans was in line with the strong financial condition of the nonfinancial business sector: The aggregated debt-service burden for nonfinancial corporations, measured as the ratio of net interest payments to cash flow, remained near its low of 1997 and less than half its peak level earlier in the decade (chart 22), and business failures remained at the low end of the range seen over the past decade.

Measures of household financial stress were also relatively stable last year, although some were at high levels. The annual increase in personal bankruptcy filings has been about 3 percent for the past year and a half, sharply down from annual increases of roughly 25 percent between early 1995 and early 1997. Although household debt grew rapidly last year, lower interest rates and longer loan maturities, which resulted from the shift toward mortgage finance, helped mitigate the effects of increased borrowing on household debt-service burdens. Reflecting these trends, the delinquency and charge-off rates on consumer loans varied little, although they tended to be on the high side of historical norms. By contrast, delinquency and charge-off rates on household mortgages stayed low.

The net charge-off rate on loans other than business, consumer, and real estate loans, which had been less than 0.1 percent per year in the preceding three years, ticked up to 0.4 percent in 1998. More than
22. Debt burden of businesses, 1985-98

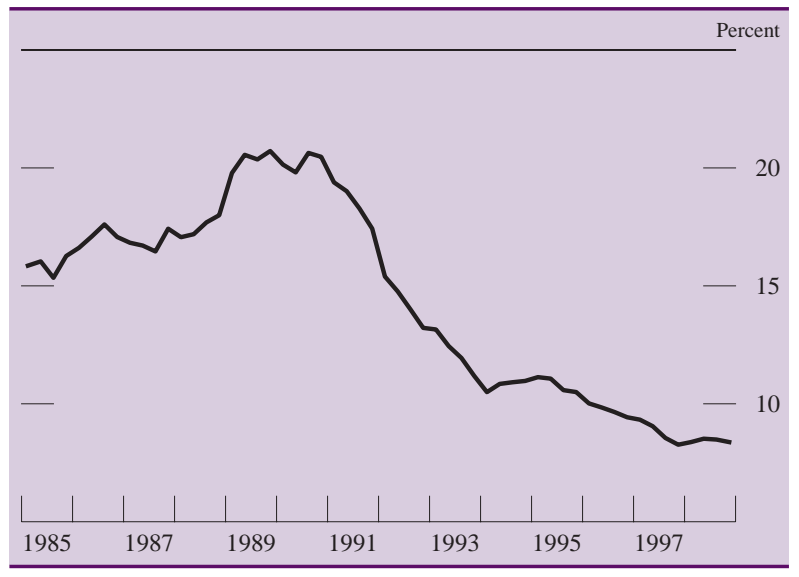

NoTE. The data are quarterly. Debt burden is for nonfinancial corporations and is calculated as interest payments as a percentage of cash flow.

Source. National income and product accounts and the Federal Reserve System.

half of those charge-offs occurred during the turbulent third quarter, when some loans to hedge funds were written off and when some banks' counterparties on derivatives transactions defaulted.

Of course, the strength of the economy was responsible for much of the continued good overall loan performance last year. If the economy were to slow, loan losses would probably rise, perhaps markedly if the easing in bank lending standards during the current long expansion turns out to have been excessive. At the end of last year, reserves for loan and lease losses remained high relative to delinquent loans (chart 23). However, relative to net charge-offs, reserves have fallen in recent years and are now near the middle of their historical range.

On the one hand, it seems sensible to compare reserves to delinquencies, because it is for losses that are probable at the time that banks should be setting

23. Measures of reserves for loan and lease losses, 1985-98

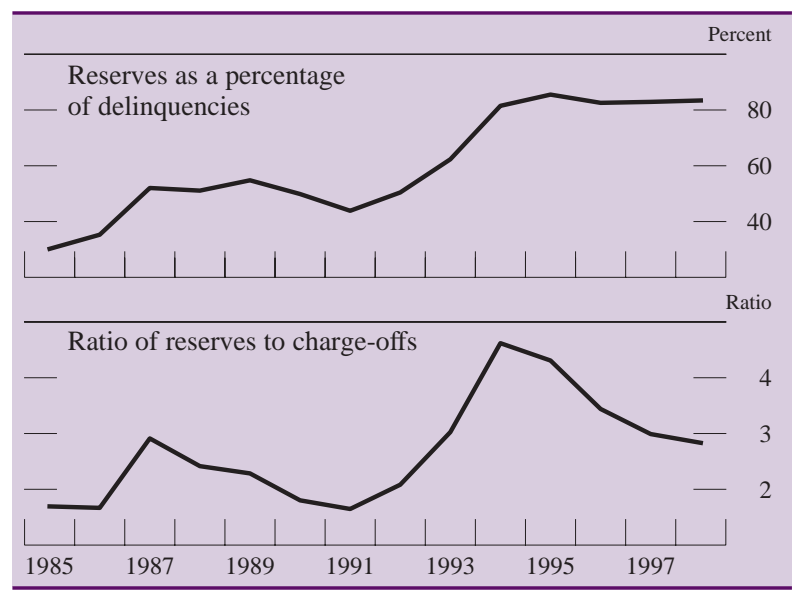


aside reserves. On the other hand, one may want to compare reserves to net charge-offs, because different loan types have different levels of losses for the same level of delinquencies. As a result, changes in the distribution of banks' delinquent loans can affect the expected level of losses for a given level of delinquencies. In particular, the average ratio of chargeoffs to delinquencies on consumer loans is well above the average for other loan types. Given the shift in the composition of delinquent loans toward consumer loans in recent years, the ratio to net charge-offs is probably a more reliable measure of the adequacy of loan-loss reserves, suggesting that banks, in the aggregate, do not appear particularly over- or underreserved. ${ }^{14}$

\section{International Operations of U.S. Banks}

Lingering concerns over economic prospects in Asia and growing worries over Latin America, Russia, and Eastern Europe led many banks to scale back their foreign operations last year. The share of U.S. bank assets booked at foreign offices fell nearly 2 percentage points to about 13 percent in 1998, after having risen by nearly 3 percentage points since 1993 (table 4). The share of income attributable to foreign operations fell from $10^{1 / 4}$ percent in the previous year to $81 / 2$ percent-the lowest since 1989 . Foreign income had been relatively high in the first half of the year, but declined sharply in the third quarter and remained low in the fourth quarter. The drop in the

14. Indeed, if loan-loss reserves are compared with delinquencies weighted, for each loan component, by the average ratio of chargeoffs to delinquencies of that component in recent years, the adequacy of loan-loss reserves appears to be about as it does when reserves are compared with net charge-offs.
4. Share of U.S. bank assets booked at foreign offices and net income attributable to foreign operations, 1993-98 Percent

\begin{tabular}{|c|c|c|}
\hline Year & Assets & Net income \\
\hline $1993 \ldots \ldots \ldots$ & 12.15 & 16.34 \\
\hline $1994 \ldots \ldots$. & 13.21 & 11.94 \\
\hline $1995 \ldots \ldots$ & 13.64 & 11.61 \\
\hline $1996 \ldots \ldots \ldots$ & 14.76 & 12.02 \\
\hline $1997 \ldots \ldots$. & 15.04 & 10.27 \\
\hline $1998 \ldots \ldots$ & 13.17 & 8.48 \\
\hline Q1 $\ldots$ & 14.96 & 11.13 \\
\hline Q2 & 15.03 & 12.68 \\
\hline Q3 $\ldots$. & 14.44 & 3.70 \\
\hline $\mathrm{Q} 4 \ldots$ & 13.17 & 5.84 \\
\hline
\end{tabular}

Note. Foreign offices include Edge Act and agreement subsidiaries and international banking facilities (IBFs). Edge Act and agreement subsidiaries are federally or state-chartered corporations, respectively, that are domiciled in the United States but engage in international banking activities. An IBF is a set of asset and liability accounts that cover selected international transactions of the U.S. offices of the bank

third quarter was concentrated in noninterest income, perhaps owing to losses on trading account securities booked abroad, and was widespread among those banks with significant foreign operations. ${ }^{15}$

The decline in foreign revenue also resulted from efforts by banks to lessen their exposure to troubled foreign economies. The exposure of U.S. commercial banks, as a fraction of capital, to troubled Asian, Eastern European, and Russian economies declined about one-fourth from year-end 1997 to year-end 1998 (table 5). The exposure of money center and other large banks to Russia declined from over 3 percent of capital to less than $1 / 2$ percent, as many of these institutions wrote off a large fraction of Russian obligations. The exposure to Latin American econo-

15. For additional details on the international operations of U.S. banks, see English and Nelson, "Profits and Balance Sheet Developments at U.S. Commercial Banks in 1997," p. 406.

5. Exposure of U.S. banking organizations to selected economies, relative to capital, year-end 1997 and 1998 Percent except as noted

\begin{tabular}{|c|c|c|c|c|c|c|c|c|}
\hline \multirow[t]{2}{*}{ Region or country } & \multicolumn{2}{|c|}{ All reporting } & \multicolumn{2}{|c|}{$\begin{array}{l}\text { Money center } \\
\text { and other large banks }\end{array}$} & \multicolumn{2}{|c|}{ All other banks } & \multicolumn{2}{|c|}{$\begin{array}{l}\text { Мвмо: } \\
\text { Total exposure, all banks } \\
\text { (billions of dollars) }\end{array}$} \\
\hline & 1997 & 1998 & 1997 & 1998 & 1997 & 1998 & 1997 & 1998 \\
\hline Troubled Asia ${ }^{1}$ & 16.11 & 9.47 & 26.87 & 15.17 & 2.34 & 1.21 & 55.24 & 37.87 \\
\hline 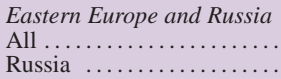 & $\begin{array}{l}3.47 \\
1.80\end{array}$ & $\begin{array}{r}2.13 \\
.26\end{array}$ & $\begin{array}{l}6.12 \\
3.16\end{array}$ & $\begin{array}{r}3.54 \\
.43\end{array}$ & $\begin{array}{l}.08 \\
.05\end{array}$ & $\begin{array}{r}.09 \\
0.00\end{array}$ & $\begin{array}{r}11.91 \\
6.16\end{array}$ & $\begin{array}{l}8.53 \\
1.05\end{array}$ \\
\hline $\begin{array}{l}\text { Latin America } \\
\text { All ............ } \\
\text { Brazil ........ }\end{array}$ & $\begin{array}{r}29.67 \\
9.74\end{array}$ & $\begin{array}{r}26.24 \\
6.89\end{array}$ & $\begin{array}{l}48.37 \\
16.13\end{array}$ & $\begin{array}{l}40.56 \\
10.76\end{array}$ & $\begin{array}{l}5.73 \\
1.56\end{array}$ & $\begin{array}{l}5.53 \\
0.00\end{array}$ & $\begin{array}{r}101.73 \\
33.40\end{array}$ & $\begin{array}{r}104.96 \\
27.55\end{array}$ \\
\hline Total & 49.25 & 37.84 & 81.37 & 59.27 & 8.16 & 6.83 & 168.89 & 151.36 \\
\hline
\end{tabular}

Note. Exposures include the institutions' lending and derivatives exposures for cross-border as well as local-office operations. Respondents may file information on one bank or on the bank holding company as a whole. Capital is defined as equity, subordinated debt, and loan-loss reserves.

1. Indonesia, Korea, Malaysia, Philippines, and Thailand. Source. Federal Financial Institutions Examination Council, Country Exposure Report. 
mies at these large banks fell nearly 8 percentage points to a bit over 40 percent of capital, with much of the decline resulting from reduced exposures to Brazil.

\section{DEVELOPMENTS IN 1999}

Responding, in part, to earnings concerns, but also to the devaluation and subsequent floating of the Brazilian real, indexes of bank stock prices fell in January. However, as evidence accumulated that the U.S. economy continued to enjoy strong growth and low inflation, and emerging-market economies appeared to stabilize, bank equities recovered. The stock prices of money center bank holding companies were up about 10 percent for the year through April; those of regional banks were about 4 percent higher, half the rise in the broader market.

Bank stock prices were lifted by first-quarter earnings announcements, which generally exceeded expectations. Bank holding companies again reported hefty gains in fee income, including fees from consumer lending, mortgage banking, and investment banking. Trading revenue also contributed to the gains, in part because credit-risk spreads on emerging-market securities narrowed.

Assets at the domestic offices of U.S. commercial banks were about unchanged in the first quarter of 1999, with weakness in many of the components that had expanded in the wake of financial turmoil in the fall. Business loans declined early in the quarter, as borrowers that had turned to banks returned to the corporate bond and commercial paper markets. Banks' holdings of mortgage-backed securities and other non-Treasury issues, which had ballooned in the fall, fell sharply. As mortgage refinancings ebbed, banks caught up on securitizing the backlog of mortgages that had been brought onto their books when refinanced, and real estate loans were about flat in the first quarter. Those loans may have been supported, in part, by further substitution for consumer loans, which edged down somewhat despite strong consumer spending.

\section{A.1. Report of income, all U.S. banks, 1989-98}

Millions of dollars

\begin{tabular}{|c|c|c|c|c|c|c|c|c|c|c|}
\hline Item & 1989 & 1990 & 1991 & 1992 & 1993 & 1994 & 1995 & 1996 & 1997 & 1998 \\
\hline Gross interest income . & 317,046 & 320,404 & 290,692 & 256,415 & 244,742 & 257,064 & 302,376 & 313,115 & 338,230 & 359,250 \\
\hline Taxable equivalent & 321,251 & 324,054 & 293,879 & 259,394 & 247,620 & 259,821 & 305,010 & 315,575 & 340,664 & 361,716 \\
\hline Loans ............... & 237,815 & 238,829 & 215,019 & 185,938 & 178,425 & 189,762 & 227,218 & 239,307 & 255,504 & 271,012 \\
\hline 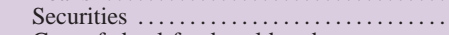 & 46,713 & 51,031 & 52,769 & 51,825 & 48,678 & 48,299 & 51,030 & 50,601 & 52,662 & 56,607 \\
\hline $\begin{array}{l}\text { Gross federal funds sold and reverse } \\
\text { repurchase agreements }\end{array}$ & 13,059 & 12,571 & 9,149 & 5,913 & 4,796 & 6,415 & 9,744 & 9,265 & 13,658 & 15,001 \\
\hline Other $\ldots \ldots \ldots \ldots \ldots$ & 19,461 & 17,971 & 13,757 & 12,739 & 12,843 & 12,587 & $\begin{array}{r}9,44 \\
14,382\end{array}$ & $\begin{array}{r}9,203 \\
13,944\end{array}$ & $\begin{array}{l}15,080 \\
16,407\end{array}$ & 16,629 \\
\hline Gross interest expense & 205,078 & 204,949 & 168,492 & 122,517 & 105,615 & 110,849 & 147,958 & 150,045 & 164,516 & 178,026 \\
\hline Deposits ............................. & 157,466 & 161,483 & 139,431 & 98,809 & 79,503 & 79,106 & 105,329 & 107,465 & 117,351 & 125,229 \\
\hline $\begin{array}{l}\text { Gross federal funds purchased and } \\
\text { repurchase agreements } \ldots . . . .\end{array}$ & 24,898 & 22,778 & 14,439 & 9,263 & 8,442 & 12,476 & 18,424 & 16,775 & 20,440 & 22,184 \\
\hline Other .............. & 22,713 & 20,687 & 14,623 & 14,441 & 17,669 & 19,269 & 24,204 & 25,806 & 26,724 & 30,612 \\
\hline Net interest income .... & 111,968 & 115,455 & 122,200 & 133,898 & 139,127 & 146,215 & 154,418 & 163,070 & 173,714 & 181,224 \\
\hline Taxable equivalent & 116,173 & 119,105 & 125,387 & 136,877 & 142,005 & 148,972 & 157,052 & 165,530 & 176,148 & 183,690 \\
\hline Loss provisioning 1 & 31,297 & 32,282 & 34,871 & 26,813 & 16,841 & 10,993 & 12,631 & 16,206 & 19,173 & 21,217 \\
\hline Noninterest income & 51,599 & 55,684 & 61,124 & 67,044 & 75,847 & 77,223 & 83,851 & 95,278 & 105,775 & 123,592 \\
\hline Servic & 10,270 & 11,446 & 12,884 & 14,12 & 14,898 & & 16,0 & & 18,558 & 19,773 \\
\hline from fiduciar & 8,313 & 8,886 & 9,499 & 10,452 & 11,199 & 12,124 & 12,890 & 14,288 & 16,604 & 18,972 \\
\hline Trading inco & 4,051 & 4,854 & 5,954 & 6,273 & 9,238 & 6,249 & 6,337 & 7,526 & 8,020 & 7,678 \\
\hline Other . & 28,965 & 30,497 & 32,785 & 36,193 & 40,513 & 43,572 & 48,567 & 56,421 & 62,593 & 77,172 \\
\hline Noninterest expense & 108,993 & 116,606 & 126,665 & 132,815 & 140,523 & 144,905 & 151,137 & 162,399 & 170,995 & 193,719 \\
\hline Salaric & 49,412 & 52,1 & 53,81 & 55,4 & & 60 & 64,0 & & & 79,521 \\
\hline of premises and fixe & 16,697 & 17,547 & 17,984 & 18,152 & 18,578 & 18,978 & 19,760 & & 22,082 & 24,161 \\
\hline Other . .............. & 42,885 & 46,948 & 54,871 & 59,181 & 63,439 & 65,023 & 67,363 & 73,741 & 76,567 & 90,038 \\
\hline Net noninterest expense & 57,394 & 60,922 & 65,541 & 65,771 & 64,676 & 67,682 & 67,286 & 67,121 & 65,220 & 70,127 \\
\hline $\begin{array}{l}\text { Realized gains on investment account } \\
\text { securities .............................. }\end{array}$ & 800 & 474 & 2,897 & 3,957 & 3,054 & -560 & 481 & 1,123 & 1,826 & 3,088 \\
\hline Income before taxes and extraor & & & & & & & & & & \\
\hline $\begin{array}{c}\text { items } \ldots \ldots \ldots \ldots \\
\text { Taxes }\end{array}$ & $\begin{array}{r}24,079 \\
9547\end{array}$ & $\begin{array}{r}22,725 \\
7,749\end{array}$ & $\begin{array}{r}24,684 \\
8,292\end{array}$ & $\begin{array}{l}45,273 \\
14,450\end{array}$ & $\begin{array}{l}60,662 \\
19,861\end{array}$ & $\begin{array}{l}66,989 \\
22,430\end{array}$ & $\begin{array}{l}74,980 \\
26,222\end{array}$ & $\begin{array}{l}80,864 \\
28,430\end{array}$ & $\begin{array}{l}91,145 \\
31,988\end{array}$ & $\begin{array}{l}92,967 \\
31,941\end{array}$ \\
\hline $\begin{array}{l}\text { Taxes } \ldots \ldots \ldots \ldots . . . . . . . . \\
\text { Extraordinary items }\end{array}$ & 312 & 650 & 1,198 & 401 & 2,085 & $\begin{array}{r}22,450 \\
-17\end{array}$ & 28 & & 56 & 508 \\
\hline Net income & 14,843 & 15,626 & 17,590 & 31,224 & 42,886 & 44,542 & 48,785 & 52,521 & 59,211 & 61,535 \\
\hline Cash dividends declared & 14,127 & 13,965 & 15,562 & 14,226 & 22,068 & 28,164 & 31,105 & 39,391 & 42,726 & 41,300 \\
\hline Retained income & 716 & 1,661 & 2,028 & 16,997 & 20,816 & 16,377 & 17,681 & 13,131 & 16,485 & 20,233 \\
\hline
\end{tabular}

1. Includes provisions for loan and lease losses and for allocated transfer risk. 
A.2. Portfolio composition, interest rates, and income and expense, all U.S. banks, 1989-98 A. All banks

\begin{tabular}{|c|c|c|c|c|c|c|c|c|c|c|}
\hline Item & 1989 & 1990 & 1991 & 1992 & 1993 & 1994 & 1995 & 1996 & 1997 & 1998 \\
\hline & \multicolumn{10}{|c|}{ Balance sheet items as a percentage of average net consolidated assets } \\
\hline Interest-earning assets . & 87.94 & 87.82 & 88.04 & 88.33 & 88.50 & 86.55 & 86.47 & 86.80 & 86.58 & 86.26 \\
\hline Loans and leases, net & 60.64 & 60.53 & 59.55 & 57.30 & 56.25 & 56.07 & 58.37 & 59.89 & 58.69 & 58.32 \\
\hline Commercial and industrial & 19.09 & 18.50 & 17.33 & 15.78 & 14.88 & 14.51 & 15.20 & 15.60 & 15.78 & 16.37 \\
\hline U.S. addressees ......... & 16.54 & 15.99 & 15.00 & 13.54 & 12.72 & 12.35 & 12.87 & 13.07 & 13.18 & 13.62 \\
\hline Foreign addressees & 2.55 & 2.51 & 2.33 & 2.24 & 2.16 & 2.16 & 2.33 & 2.53 & 2.60 & 2.75 \\
\hline Consumer ........... & 11.89 & 11.77 & 11.45 & 11.00 & 11.00 & 11.43 & 12.08 & 12.21 & 11.44 & 10.36 \\
\hline Credit card .......... & 3.69 & 3.78 & 3.88 & 3.80 & 3.88 & 4.21 & 4.69 & 4.87 & 4.55 & 3.97 \\
\hline Installment and other & 8.20 & 7.99 & 7.57 & 7.20 & 7.11 & 7.22 & 7.39 & 7.34 & 6.89 & 6.39 \\
\hline Real estate ........... & 22.50 & 23.86 & 24.87 & 24.87 & 24.80 & 24.43 & 25.01 & 25.06 & 25.02 & 24.86 \\
\hline In domestic offices $\ldots \ldots \ldots \ldots$ & 21.78 & 23.10 & 24.11 & 24.18 & 24.18 & 23.80 & 24.36 & 24.43 & 24.41 & 24.29 \\
\hline Construction and land development & 4.16 & 4.00 & 3.41 & 2.64 & 1.99 & 1.65 & 1.59 & 1.63 & 1.73 & 1.86 \\
\hline Farmland $\ldots \ldots \ldots \ldots \ldots \ldots \ldots \ldots$ & .51 & .51 & .53 & .56 & .57 & .56 & .56 & .56 & .55 & .55 \\
\hline One- to four-family residential & 10.15 & 11.21 & 12.27 & 12.91 & 13.49 & 13.74 & 14.42 & 14.43 & 14.42 & 14.26 \\
\hline Home equity..$\ldots \ldots \ldots \ldots$ & 1.42 & 1.67 & 1.95 & 2.09 & 2.07 & 1.91 & 1.88 & 1.85 & 1.94 & 1.89 \\
\hline Other $\ldots \ldots \ldots \ldots$ & 8.73 & 9.54 & 10.32 & 10.83 & 11.42 & 11.84 & 12.54 & 12.57 & 12.48 & 12.37 \\
\hline Multifamily residential & .60 & .62 & .66 & .75 & .79 & .79 & .81 & .85 & .83 & .82 \\
\hline Nonfarm nonresidential & 6.36 & 6.76 & 7.23 & 7.32 & 7.33 & 7.07 & 6.97 & 6.96 & 6.88 & 6.81 \\
\hline In foreign offices ........ & .72 & .76 & .76 & .69 & .62 & .63 & .65 & .63 & .61 & .57 \\
\hline Depository institutions & 1.76 & 1.60 & 1.42 & 1.24 & 1.08 & 1.42 & 1.88 & 2.29 & 1.89 & 1.88 \\
\hline Foreign governments .. & 1.03 & .78 & .75 & .73 & .67 & .41 & .30 & .26 & .18 & .15 \\
\hline Agricultural production & .96 & .96 & 1.01 & 1.02 & .99 & 1.00 & .96 & .92 & .90 & .89 \\
\hline Other loans .............. & 4.31 & 3.93 & 3.60 & 3.50 & 3.56 & 3.34 & 3.15 & 3.36 & 2.84 & 2.81 \\
\hline Lease-financing receivables .... & 1.10 & 1.12 & 1.09 & 1.03 & .99 & 1.03 & 1.19 & 1.51 & 1.87 & 2.14 \\
\hline LESS: Unearned income on loans & -.48 & -.42 & -.36 & -.28 & -.21 & -.16 & -.14 & -.12 & -.09 & -.07 \\
\hline LEss: Loss reserves ${ }^{1} \ldots \ldots \ldots \ldots$ & -1.52 & -1.57 & -1.62 & -1.60 & -1.51 & -1.36 & -1.26 & -1.21 & -1.13 & -1.07 \\
\hline Securities ............ & 18.39 & 19.09 & 20.70 & 23.52 & 25.37 & 24.27 & 21.94 & 21.01 & 20.41 & 20.38 \\
\hline Investment account & 17.14 & 17.63 & 18.93 & 21.18 & 22.50 & 21.60 & 19.39 & 18.20 & 17.25 & 17.48 \\
\hline Debt ........... & 16.84 & 17.37 & 18.62 & 20.82 & 22.12 & 21.21 & 18.98 & 17.75 & 16.75 & 16.94 \\
\hline U.S. Treasury $\ldots \ldots \ldots \ldots$ & 4.98 & 4.57 & 5.06 & 6.49 & 7.08 & 6.77 & 5.25 & 4.20 & 3.38 & 2.71 \\
\hline U.S. government agency and & & & & & & & & & & \\
\hline corporation obligations $\ldots \ldots \ldots$ & 6.04 & 7.56 & 8.75 & 9.86 & 10.73 & 10.24 & 9.81 & 9.75 & 9.74 & 10.28 \\
\hline Government-backed mortgage pools & 3.27 & 4.08 & 4.51 & 4.52 & 4.74 & 4.67 & 4.47 & 4.80 & 4.94 & 5.17 \\
\hline Collateralized mortgage obligations & n.a. & 1.25 & 2.07 & 3.12 & 3.72 & 3.24 & 2.67 & 2.11 & 1.94 & 2.12 \\
\hline Other $\ldots \ldots \ldots \ldots \ldots \ldots \ldots \ldots \ldots$ & 2.77 & 2.22 & 2.16 & 2.21 & 2.27 & 2.33 & 2.68 & 2.83 & 2.86 & 2.99 \\
\hline State and local government $\ldots$ & 3.15 & 2.64 & 2.28 & 2.08 & 2.06 & 2.02 & 1.80 & 1.68 & 1.59 & 1.57 \\
\hline Private mortgage-backed securities & n.a. & n.a. & .94 & $\begin{array}{r}2.00 \\
.82\end{array}$ & .73 & .64 & .62 & .61 & .50 & .67 \\
\hline Other $\ldots \ldots \ldots \ldots \ldots \ldots \ldots \ldots$ & 2.68 & 2.59 & 1.59 & 1.58 & 1.52 & 1.54 & 1.49 & 1.51 & 1.54 & 1.70 \\
\hline Equity $\ldots \ldots \ldots \ldots$ & .30 & .27 & .31 & .37 & .38 & .39 & .41 & .45 & .50 & .55 \\
\hline Trading account $\ldots \ldots \ldots \ldots \ldots \ldots \ldots \ldots$ & 1.25 & 1.46 & 1.77 & 2.34 & 2.87 & 2.67 & 2.55 & 2.81 & 3.16 & 2.89 \\
\hline Gross federal funds sold and reverse RPs & 4.33 & 4.46 & 4.58 & 4.54 & 4.27 & 3.82 & 3.93 & 3.82 & 5.18 & 5.37 \\
\hline Interest-bearing balances at depositories .. & 4.58 & 3.75 & 3.21 & 2.97 & 2.62 & 2.40 & 2.23 & 2.08 & 2.29 & 2.19 \\
\hline 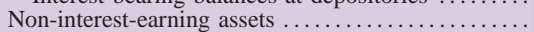 & 12.06 & 12.18 & 11.96 & 11.67 & 11.50 & 13.45 & 13.53 & 13.20 & 13.42 & 13.74 \\
\hline Revaluation gains on off-balance-sheet items ${ }^{2}$ & n.a. & n.a. & n.a. & n.a. & n.a. & 2.61 & 2.90 & 2.25 & 2.59 & 2.95 \\
\hline Other $\ldots \ldots \ldots \ldots \ldots \ldots \ldots \ldots \ldots \ldots \ldots \ldots \ldots \ldots \ldots$ & 12.06 & 12.18 & 11.96 & 11.67 & 11.50 & 10.84 & 10.62 & 10.95 & 10.83 & 10.79 \\
\hline Liabilities ............... & 93.64 & 93.60 & 93.33 & 92.82 & 92.15 & 92.12 & 91.99 & 91.73 & 91.57 & 91.51 \\
\hline Interest-bearing liabilities & 76.02 & 76.53 & 76.58 & 75.32 & 73.92 & 71.86 & 71.86 & 71.62 & 71.36 & 71.35 \\
\hline Deposits ............. & 62.58 & 63.44 & 64.45 & 62.94 & 60.26 & 57.34 & 56.30 & 55.87 & 55.01 & 54.67 \\
\hline In foreign offices & 9.68 & 9.26 & 8.55 & 8.37 & 8.32 & 9.39 & 10.28 & 10.01 & 10.02 & 10.15 \\
\hline In domestic offices ........ & 52.90 & 54.18 & 55.90 & 54.56 & 51.94 & 47.96 & 46.03 & 45.86 & 44.99 & 44.53 \\
\hline Other checkable deposits ... & 6.12 & 6.19 & 6.72 & 7.65 & 8.24 & 7.80 & 6.63 & 4.75 & 3.62 & 3.12 \\
\hline Savings (including MMDAs) ..... & 16.28 & 16.59 & 18.00 & 20.28 & 20.91 & 19.60 & 17.48 & 18.71 & 19.13 & 19.92 \\
\hline Small-denomination time deposits & 18.38 & 19.96 & 21.30 & 19.21 & 16.98 & 15.33 & 16.14 & 15.97 & 15.17 & 14.16 \\
\hline Large-denomination time deposits & 12.13 & 11.44 & 9.89 & 7.42 & 5.81 & 5.23 & 5.77 & 6.42 & 7.08 & 7.34 \\
\hline Gross federal funds purchased and RPs ... & 8.22 & 8.03 & 7.09 & 7.02 & 7.47 & 7.60 & 7.71 & 7.18 & 8.13 & 7.99 \\
\hline Other $\ldots \ldots \ldots \ldots \ldots \ldots \ldots \ldots \ldots \ldots$ & 5.22 & 5.07 & 5.03 & 5.36 & 6.19 & 6.92 & 7.85 & 8.56 & 8.21 & 8.69 \\
\hline Non-interest-bearing liabilities $\ldots \ldots \ldots \ldots \ldots \ldots$ & 17.62 & 17.07 & 16.75 & 17.50 & 18.23 & 20.26 & 20.13 & 20.11 & 20.21 & 20.15 \\
\hline Demand deposits in domestic offices .......... & 13.49 & 12.79 & 12.59 & 13.24 & 13.86 & 13.49 & 12.68 & 12.82 & 12.16 & 11.00 \\
\hline Revaluation losses on off-balance-sheet items ${ }^{2}$ & n.a. & n.a. & n.a. & n.a. & n.a. & 2.32 & 2.88 & 2.14 & 2.64 & 2.97 \\
\hline 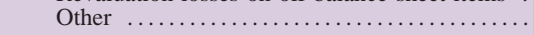 & 4.13 & 4.27 & 4.16 & 4.27 & 4.37 & 4.45 & 4.57 & 5.14 & 5.41 & 6.18 \\
\hline Capital account & 6.36 & 6.40 & 6.67 & 7.18 & 7.85 & 7.88 & 8.01 & 8.27 & 8.43 & 8.49 \\
\hline Мемо & & & & & & & & & & \\
\hline Commercial real estate loans & n.a. & n.a. & 12.02 & 11.34 & 10.63 & 9.94 & 9.83 & 9.92 & 9.99 & 10.12 \\
\hline Other real estate owned ..... & .39 & .50 & .75 & .82 & .63 & .36 & .19 & .14 & .11 & .08 \\
\hline Managed liabilities.......... & 35.78 & 34.31 & 31.05 & 28.70 & 28.28 & 29.61 & 32.08 & 32.73 & 34.09 & 34.95 \\
\hline $\begin{array}{l}\text { Average net consolidated assets } \\
\text { (billions of dollars) }\end{array}$ & 3,187 & 3,338 & 3,379 & 3,442 & 3,566 & 3,863 & 4,148 & 4,376 & 4,733 & 5,145 \\
\hline
\end{tabular}




\section{A.2.-Continued}

A. All banks

\begin{tabular}{|c|c|c|c|c|c|c|c|c|c|c|}
\hline Item & 1989 & 1990 & 1991 & 1992 & 1993 & 1994 & 1995 & 1996 & 1997 & 1998 \\
\hline & \multicolumn{10}{|c|}{ Effective interest rate (percent) ${ }^{3}$} \\
\hline \multicolumn{11}{|l|}{ Rates earned } \\
\hline Interest-earning assets . & 11.13 & 10.67 & 9.57 & 8.27 & 7.61 & 7.61 & 8.33 & 8.14 & 8.15 & 7.99 \\
\hline Taxable equivalent .. & 11.29 & 10.80 & 9.69 & 8.37 & 7.71 & 7.70 & 8.41 & 8.21 & 8.22 & 8.06 \\
\hline Loans and leases, gross ... & 12.02 & 11.49 & 10.40 & 9.20 & 8.69 & 8.62 & 9.25 & 8.99 & 9.01 & 8.85 \\
\hline Net of loss provisions & 10.44 & 9.94 & 8.72 & 7.87 & 7.87 & 8.12 & 8.74 & 8.39 & 8.34 & 8.15 \\
\hline Securities ................ & 8.73 & 8.79 & 8.19 & 7.04 & 6.08 & 5.96 & 6.51 & 6.42 & 6.50 & 6.37 \\
\hline Taxable equivalent & 9.25 & 9.21 & 8.56 & 7.34 & 6.36 & 6.20 & 6.73 & 6.66 & 6.73 & 6.63 \\
\hline Investment account $\ldots \ldots \ldots \ldots \ldots$ & 8.55 & 8.67 & 8.25 & 7.11 & 6.07 & 5.79 & 6.35 & 6.35 & 6.45 & 6.29 \\
\hline U.S. government and other debt & 8.83 & 8.92 & 8.43 & 7.18 & 6.07 & 5.80 & 6.42 & 6.47 & 6.60 & 6.45 \\
\hline State and local $\ldots \ldots \ldots \ldots \ldots$ & 7.45 & 7.39 & 7.25 & 6.81 & 6.25 & 5.87 & 5.82 & 5.55 & 5.41 & 5.23 \\
\hline Equity ......... & 7.70 & 7.34 & 6.20 & 5.32 & 4.79 & 4.79 & 5.51 & 5.23 & 5.15 & 4.92 \\
\hline Trading account $\ldots \ldots \ldots \ldots \ldots \ldots \ldots \ldots$ & 11.11 & 10.15 & 7.54 & 6.40 & 6.16 & 7.41 & 7.73 & 6.86 & 6.75 & 6.85 \\
\hline Gross federal funds sold and reverse RPs & 9.17 & 8.08 & 5.69 & 3.58 & 3.04 & 4.26 & 5.63 & 5.21 & 5.45 & 5.29 \\
\hline Interest-bearing balances at depositories ..... & 10.59 & 9.96 & 8.44 & 7.31 & 6.61 & 5.71 & 6.84 & 6.21 & 6.24 & 6.27 \\
\hline \multicolumn{11}{|l|}{ Rates paid } \\
\hline Interest-bearing liabilities. & 8.53 & 8.04 & 6.55 & 4.75 & 4.01 & 4.01 & 4.99 & 4.82 & 4.92 & 4.88 \\
\hline Interest-bearing deposits & 7.87 & 7.57 & 6.34 & 4.51 & 3.65 & 3.53 & 4.47 & 4.33 & 4.39 & 4.31 \\
\hline In foreign offices $\ldots .$. & 10.87 & 10.71 & 8.54 & 7.32 & 6.82 & 5.59 & 6.12 & 5.54 & 5.44 & 5.66 \\
\hline In domestic offices ........ & 7.32 & 7.02 & 6.00 & 4.07 & 3.14 & 3.14 & 4.11 & 4.07 & 4.16 & 4.01 \\
\hline Other checkable deposits & 4.83 & 4.79 & 4.34 & 2.70 & 1.99 & 1.85 & 2.06 & 2.03 & 2.25 & 2.29 \\
\hline Savings (including MMDAs) ...... & 6.18 & 5.99 & 5.11 & 3.25 & 2.50 & 2.58 & 3.19 & 2.99 & 2.93 & 2.79 \\
\hline Large-denomination time deposits 4 & 8.66 & 8.03 & 6.69 & 4.90 & 4.00 & 4.09 & 5.47 & 5.39 & 5.45 & 5.22 \\
\hline Small-denomination time deposits ${ }^{4}$ & 8.29 & 7.97 & 6.93 & 5.15 & 4.19 & 4.17 & 5.44 & 5.40 & 5.54 & 5.47 \\
\hline Gross federal funds purchased and RPs $\ldots \ldots$. & 9.20 & 7.97 & 5.76 & 3.64 & 3.07 & 4.18 & 5.65 & 5.12 & 5.17 & 5.19 \\
\hline \multirow[t]{2}{*}{ Other interest-bearing liabilities $\ldots \ldots \ldots \ldots \ldots$} & 13.76 & 12.26 & 8.65 & 7.87 & 8.02 & 7.25 & 7.47 & 6.93 & 6.95 & 6.88 \\
\hline & \multicolumn{10}{|c|}{ Income and expense as a percentage of average net consolidated assets } \\
\hline Gross interest income. & 9.95 & 9.60 & 8.60 & 7.45 & 6.86 & 6.65 & 7.29 & 7.16 & 7.15 & 6.98 \\
\hline Taxable equivalent & 10.08 & 9.71 & 8.70 & 7.54 & 6.94 & 6.73 & 7.35 & 7.21 & 7.20 & 7.03 \\
\hline Loans ............. & 7.46 & 7.15 & 6.36 & 5.40 & 5.00 & 4.91 & 5.48 & 5.47 & 5.40 & 5.27 \\
\hline Securities $\ldots \ldots \ldots \ldots \ldots \ldots \ldots \ldots \ldots$ & 1.47 & 1.53 & 1.56 & 1.51 & 1.37 & 1.25 & 1.23 & 1.16 & 1.11 & 1.10 \\
\hline Gross federal funds sold and reverse RPs & .41 & .38 & .27 & .17 & .13 & .17 & .23 & .21 & .29 & .29 \\
\hline Other $\ldots \ldots \ldots \ldots \ldots \ldots \ldots \ldots \ldots \ldots \ldots$ & .61 & .54 & .41 & .37 & .36 & .33 & .35 & .32 & .35 & .32 \\
\hline Gross interest expense & 6.44 & 6.14 & 4.99 & 3.56 & 2.96 & 2.87 & 3.57 & 3.43 & 3.48 & 3.46 \\
\hline 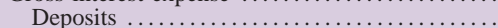 & 4.94 & 4.84 & 4.13 & 2.87 & 2.23 & 2.05 & 2.54 & 2.46 & 2.48 & 2.43 \\
\hline Gross federal funds purchased and RPs & .78 & .68 & .43 & .27 & .24 & .32 & .44 & .38 & .43 & .43 \\
\hline Other $\ldots \ldots \ldots \ldots \ldots \ldots \ldots \ldots \ldots \ldots \ldots$ & .71 & .62 & .43 & .42 & .50 & .50 & .58 & .59 & .56 & .60 \\
\hline Net interest income .... & 3.51 & 3.46 & 3.62 & 3.89 & 3.90 & 3.78 & 3.72 & 3.73 & 3.67 & 3.52 \\
\hline Taxable equivalent & 3.65 & 3.57 & 3.71 & 3.98 & 3.98 & 3.86 & 3.79 & 3.78 & 3.72 & 3.57 \\
\hline Loss provisioning 5 ... & .98 & .97 & 1.03 & .78 & .47 & .28 & .30 & .37 & .41 & .41 \\
\hline Noninterest income .......... & 1.62 & 1.67 & 1.81 & 1.95 & 2.13 & 2.00 & 2.02 & 2.18 & 2.23 & 2.40 \\
\hline Service charges on deposits ... & .32 & .34 & .38 & .41 & .42 & .40 & .39 & .39 & .39 & .38 \\
\hline Income from fiduciary activities & .26 & .27 & .28 & .30 & .31 & .31 & .31 & .33 & .35 & .37 \\
\hline Trading income $\ldots . . . \ldots \ldots \ldots$ & .13 & .15 & .18 & .18 & .26 & .16 & .15 & .17 & .17 & .15 \\
\hline Interest rate exposures $\ldots \ldots \ldots$ & n.a. & n.a. & n.a. & n.a. & n.a. & n.a. & n.a. & .09 & .08 & .05 \\
\hline Foreign exchange exposures $\ldots \ldots \ldots \ldots$ & n.a. & n.a. & n.a. & n.a. & n.a. & n.a. & n.a. & .06 & .08 & .09 \\
\hline Equity, commodity, and other exposures & n.a. & n.a. & n.a. & n.a. & n.a. & n.a. & n.a. & .02 & $*$ & .01 \\
\hline 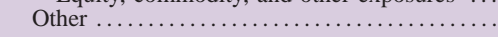 & .91 & .91 & .97 & 1.05 & 1.14 & 1.13 & 1.17 & 1.29 & 1.32 & 1.50 \\
\hline Noninterest expense $\ldots \ldots \ldots \ldots \ldots \ldots \ldots$ & 3.42 & 3.49 & 3.75 & 3.86 & 3.94 & 3.75 & 3.64 & 3.71 & 3.61 & 3.77 \\
\hline Salaries, wages, and employee benefits & 1.55 & 1.56 & 1.59 & 1.61 & 1.64 & 1.58 & 1.54 & 1.55 & 1.53 & 1.55 \\
\hline Expenses of premises and fixed assets. & .52 & .53 & .53 & .53 & .52 & .49 & .48 & .48 & .47 & .47 \\
\hline Other $\ldots \ldots \ldots \ldots \ldots \ldots$ & 1.35 & 1.41 & 1.62 & 1.72 & 1.78 & 1.68 & 1.62 & 1.69 & 1.62 & 1.75 \\
\hline Net noninterest expense & 1.80 & 1.83 & 1.94 & 1.91 & 1.81 & 1.75 & 1.62 & 1.53 & 1.38 & 1.36 \\
\hline Realized gains on investment account securities & .03 & .01 & .09 & .11 & .09 & -.01 & .01 & .03 & .04 & .06 \\
\hline Income before taxes and extraordinary items ... & .76 & .68 & .73 & 1.32 & 1.70 & 1.73 & 1.81 & 1.85 & 1.93 & 1.81 \\
\hline 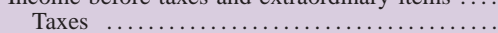 & .30 & .23 & .25 & .42 & .56 & .58 & .63 & .65 & .68 & .62 \\
\hline Extraordinary items $\ldots . .$. & .01 & .02 & .04 & .01 & .06 & $*$ & $*$ & $*$ & $*$ & .01 \\
\hline Net income (return on assets) & .47 & .47 & .52 & .91 & 1.20 & 1.15 & 1.18 & 1.20 & 1.25 & 1.20 \\
\hline Cash dividends declared ... & .44 & .42 & .46 & .41 & .62 & .73 & .75 & .90 & .90 & .80 \\
\hline Retained income ....... & .02 & .05 & .06 & .49 & .58 & .42 & .43 & .30 & .35 & .39 \\
\hline Memo: Return on equity & 7.33 & 7.31 & 7.80 & 12.64 & 15.32 & 14.63 & 14.69 & 14.52 & 14.84 & 14.08 \\
\hline
\end{tabular}

* In absolute value, less than 0.005 percent.

Definitions. n.a. Not available. MMDA Money market deposit account. RP Repurchase agreement. CD Certificate of deposit.

1. Includes the allowance for loan and lease losses and the allocated transfer risk reserve.

2. Before 1994, the netted value of off-balance-sheet items appeared in "trading account securities"

if a gain and "other non-interest-bearing liabilities" if a loss.

3. When possible, based on the average of quarterly balance sheet data reported on schedule RC-K of the quarterly Call Reports.

4. Before 1997, data for large time open accounts are included in small-denomination time deposits.

5. Includes provisions for loan and lease losses and for allocated transfer risk. 
A.2. Portfolio composition, interest rates, and income and expense, all U.S. banks, 1989-98 B. Ten largest banks by assets

\begin{tabular}{|c|c|c|c|c|c|c|c|c|c|c|}
\hline Item & 1989 & 1990 & 1991 & 1992 & 1993 & 1994 & 1995 & 1996 & 1997 & 1998 \\
\hline & \multicolumn{10}{|c|}{ Balance sheet items as a percentage of average net consolidated assets } \\
\hline Interest-earning assets . & 85.16 & 84.85 & 85.41 & 85.16 & 84.79 & 76.97 & 77.02 & 79.94 & 81.62 & 81.07 \\
\hline Loans and leases, net & 59.66 & 61.69 & 62.14 & 58.34 & 55.57 & 49.91 & 50.05 & 53.51 & 50.91 & 50.77 \\
\hline Commercial and industrial & 22.61 & 22.91 & 22.42 & 20.32 & 18.65 & 16.43 & 16.16 & 17.17 & 16.90 & 18.07 \\
\hline U.S. addressees ......... & 13.18 & 13.39 & 13.44 & 12.00 & 10.75 & 9.16 & 8.66 & 9.59 & 10.24 & 11.76 \\
\hline Foreign addressees ... & 9.43 & 9.53 & 8.97 & 8.32 & 7.90 & 7.27 & 7.50 & 7.59 & 6.66 & 6.31 \\
\hline Consumer ........... & 6.21 & 6.87 & 7.20 & 7.31 & 7.33 & 6.59 & 6.60 & 6.22 & 6.40 & 6.04 \\
\hline Credit card .......... & 1.99 & 2.20 & 2.53 & 2.61 & 2.50 & 2.28 & 1.96 & 1.23 & 1.34 & 1.30 \\
\hline Installment and other & 4.22 & 4.67 & 4.67 & 4.70 & 4.83 & 4.31 & 4.65 & 4.99 & 5.06 & 4.74 \\
\hline Real estate $\ldots \ldots \ldots \ldots$ & 18.02 & 20.56 & 21.68 & 19.93 & 18.54 & 16.21 & 15.82 & 16.53 & 17.42 & 16.51 \\
\hline In domestic offices & 15.05 & 17.36 & 18.37 & 17.07 & 15.99 & 13.80 & 13.48 & 14.44 & 15.69 & 15.08 \\
\hline Construction and land development & 3.60 & 3.79 & 3.42 & 2.48 & 1.59 & .84 & .58 & .51 & .68 & .77 \\
\hline Farmland $\ldots \ldots \ldots \ldots \ldots \ldots \ldots \ldots$ & .08 & .08 & .08 & .07 & .07 & .06 & .06 & .06 & .09 & .09 \\
\hline One- to four-family residential & 7.45 & 9.31 & 10.34 & 10.08 & 10.29 & 9.69 & 9.62 & 10.43 & 11.02 & 10.33 \\
\hline Home equity $\ldots \ldots \ldots \ldots \ldots$ & 1.04 & 1.31 & 1.63 & 1.63 & 1.60 & 1.40 & 1.40 & 1.53 & 1.70 & 1.72 \\
\hline Other $\ldots \ldots \ldots \ldots$ & 6.41 & 8.00 & 8.71 & 8.46 & 8.68 & 8.29 & 8.22 & 8.90 & 9.31 & 8.61 \\
\hline Multifamily residential & .68 & .68 & .57 & .58 & .53 & .41 & .38 & .38 & .39 & .38 \\
\hline Nonfarm nonresidential & 3.23 & 3.51 & 3.95 & 3.86 & 3.51 & 2.79 & 2.83 & 3.05 & 3.52 & 3.51 \\
\hline In foreign offices ......... & 2.97 & 3.20 & 3.32 & 2.85 & 2.55 & 2.41 & 2.35 & 2.09 & 1.73 & 1.43 \\
\hline Depository institutions & 4.56 & 3.64 & 3.05 & 2.56 & 2.35 & 3.37 & 4.95 & 6.06 & 4.14 & 4.00 \\
\hline Foreign governments. & 3.34 & 2.76 & 2.88 & 2.75 & 2.46 & 1.27 & .90 & .69 & .45 & .35 \\
\hline Agricultural production & .31 & .31 & .31 & .28 & .27 & .25 & .21 & .23 & .31 & .28 \\
\hline Other loans .............. & 6.36 & 6.05 & 5.61 & 6.05 & 6.82 & 6.44 & 5.85 & 6.42 & 4.21 & 3.79 \\
\hline Lease-financing receivables .... & 1.49 & 1.60 & 1.68 & 1.51 & 1.30 & 1.14 & 1.14 & 1.59 & 2.24 & 2.81 \\
\hline LESS: Unearned income on loans & -.45 & -.39 & -.35 & -.27 & -.21 & -.16 & -.14 & -.11 & -.07 & -.06 \\
\hline LEss: Loss reserves ${ }^{1} \ldots \ldots \ldots \ldots$ & -2.77 & -2.63 & -2.34 & -2.08 & -1.94 & -1.63 & -1.45 & -1.30 & -1.08 & -1.01 \\
\hline Securities ............. & 13.13 & 14.03 & 15.58 & 19.13 & 22.74 & 20.43 & 19.53 & 19.83 & 20.00 & 19.72 \\
\hline Investment account & 9.05 & 9.22 & 9.38 & 10.70 & 12.45 & 11.68 & 10.65 & 10.60 & 10.97 & 12.12 \\
\hline Debt $\ldots \ldots \ldots \ldots$ & 8.83 & 8.98 & 9.08 & 10.36 & 12.08 & 11.30 & 10.27 & 10.22 & 10.55 & 11.65 \\
\hline U.S. Treasury $\ldots \ldots \ldots \ldots$ & 1.29 & 1.09 & 1.35 & 2.30 & 2.39 & 2.17 & 2.03 & 1.93 & 1.56 & 1.70 \\
\hline \multicolumn{11}{|l|}{ U.S. government agency and } \\
\hline corporation obligations $\ldots \ldots \ldots$ & 2.29 & 2.91 & 3.46 & 4.45 & 6.14 & 5.16 & 4.46 & 4.59 & 5.34 & 6.31 \\
\hline Government-backed mortgage pools & 2.07 & 2.24 & 2.26 & 2.43 & 3.30 & 2.79 & 2.89 & 3.58 & 4.26 & 5.13 \\
\hline Collateralized mortgage obligations & n.a. & .54 & 1.12 & 1.97 & 2.76 & 2.31 & 1.50 & .95 & .93 & .93 \\
\hline Other $\ldots \ldots \ldots \ldots \ldots \ldots \ldots$ & .22 & .14 & .08 & .05 & .08 & .06 & .08 & .06 & .15 & .26 \\
\hline State and local government & 1.58 & 1.08 & .77 & .66 & .59 & .60 & .49 & .39 & .51 & .47 \\
\hline Private mortgage-backed securities & n.a. & n.a. & .48 & .33 & .38 & .43 & .32 & .30 & .32 & .60 \\
\hline Other $\ldots \ldots \ldots \ldots \ldots \ldots \ldots \ldots$ & 3.68 & 3.90 & 3.01 & 2.62 & 2.59 & 2.94 & 2.97 & 3.01 & 2.81 & 2.57 \\
\hline Equity . & .22 & .24 & .30 & .33 & .36 & .38 & .38 & .38 & .42 & .47 \\
\hline Trading account $\ldots \ldots \ldots \ldots \ldots \ldots \ldots$ & 4.08 & 4.81 & 6.19 & 8.43 & 10.30 & 8.74 & 8.88 & 9.23 & 9.03 & 7.60 \\
\hline Gross federal funds sold and reverse RPs & 4.12 & 2.88 & 2.96 & 3.23 & 2.71 & 2.68 & 3.20 & 3.10 & 7.56 & 7.81 \\
\hline Interest-bearing balances at depositories .. & 8.26 & 6.25 & 4.74 & 4.45 & 3.76 & 3.95 & 4.25 & 3.50 & 3.15 & 2.77 \\
\hline 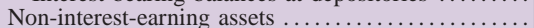 & 14.84 & 15.15 & 14.59 & 14.84 & 15.21 & 23.03 & 22.98 & 20.06 & 18.38 & 18.93 \\
\hline Revaluation gains on off-balance-sheet items $^{2}$ & n.a. & n.a. & n.a. & n.a. & n.a. & 9.89 & 10.77 & 7.63 & 7.36 & 7.61 \\
\hline 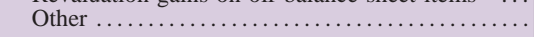 & 14.84 & 15.15 & 14.59 & 14.84 & 15.21 & 13.14 & 12.21 & 12.43 & 11.02 & 11.32 \\
\hline Liabilities..$\ldots \ldots \ldots \ldots \ldots$ & 95.11 & 95.29 & 94.97 & 94.44 & 93.24 & 93.42 & 93.59 & 93.04 & 92.61 & 92.57 \\
\hline Interest-bearing liabilities & 74.17 & 73.97 & 74.62 & 73.08 & 71.56 & 64.33 & 63.37 & 64.45 & 65.83 & 65.81 \\
\hline Deposits ............. & 57.56 & 57.95 & 57.67 & 55.73 & 52.91 & 48.20 & 47.49 & 47.87 & 47.36 & 47.65 \\
\hline In foreign offices & 30.08 & 29.66 & 28.47 & 27.16 & 25.51 & 26.10 & 28.36 & 26.41 & 22.18 & 20.17 \\
\hline In domestic offices $\ldots . . . .$. & 27.49 & 28.28 & 29.19 & 28.56 & 27.41 & 22.10 & 19.12 & 21.46 & 25.18 & 27.48 \\
\hline Other checkable deposits ... & 2.70 & 2.74 & 3.00 & 3.38 & 3.45 & 2.91 & 2.30 & 1.61 & 1.21 & $\begin{array}{r}21.40 \\
.99\end{array}$ \\
\hline Savings (including MMDAs) ..... & 11.32 & 12.05 & 13.50 & 14.91 & 15.33 & 12.70 & 10.56 & 12.31 & 14.26 & 15.84 \\
\hline Small-denomination time deposits & 5.64 & 6.16 & 6.55 & 5.72 & 5.09 & 3.98 & 4.04 & 4.68 & 5.82 & 6.03 \\
\hline Large-denomination time deposits & 7.82 & 7.33 & 6.14 & 4.56 & 3.53 & 2.51 & 2.23 & 2.86 & 3.89 & 4.62 \\
\hline Gross federal funds purchased and RPs & 6.72 & 6.90 & 6.80 & 6.19 & 6.70 & 5.83 & 6.17 & 5.88 & 10.26 & 9.79 \\
\hline Other $\ldots \ldots \ldots \ldots \ldots \ldots \ldots \ldots \ldots \ldots \ldots$ & 9.89 & 9.13 & 10.15 & 11.16 & 11.94 & 10.29 & 9.71 & 10.69 & 8.20 & 8.37 \\
\hline Non-interest-bearing liabilities $\ldots \ldots \ldots \ldots \ldots \ldots$ & 20.94 & 21.32 & 20.35 & 21.36 & 21.68 & 29.09 & 30.22 & 28.59 & 26.78 & 26.76 \\
\hline 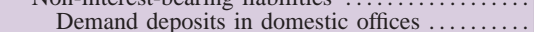 & 11.60 & 10.93 & 10.36 & 11.05 & 11.27 & 10.15 & 8.88 & 9.73 & 8.98 & 8.46 \\
\hline Revaluation losses on off-balance-sheet items ${ }^{2}$ & n.a. & n.a. & n.a. & n.a. & n.a. & 8.75 & 10.68 & 7.27 & 7.53 & 7.66 \\
\hline Other $\ldots \ldots \ldots \ldots \ldots \ldots \ldots \ldots \ldots \ldots \ldots \ldots \ldots \ldots$ & 9.34 & 10.39 & 9.99 & 10.30 & 10.41 & 10.20 & 10.66 & 11.59 & 10.27 & 10.64 \\
\hline Capital account & 4.89 & 4.71 & 5.03 & 5.56 & 6.76 & 6.58 & 6.41 & 6.96 & 7.39 & 7.43 \\
\hline \multicolumn{11}{|l|}{ Мемо } \\
\hline Commercial real estate loans & n.a. & n.a. & 9.05 & 8.01 & 6.46 & 4.65 & 4.40 & 4.65 & 5.45 & 5.61 \\
\hline Other real estate owned ..... & .23 & .42 & .78 & 1.13 & 1.02 & .58 & .27 & .18 & .13 & .09 \\
\hline Managed liabilities.......... & 56.31 & 54.79 & 53.23 & 50.82 & 49.23 & 46.21 & 47.94 & 47.39 & 46.02 & 44.43 \\
\hline $\begin{array}{l}\text { Average net consolidated assets } \\
\text { (billions of dollars) }\end{array}$ & 693 & 725 & 717 & 775 & 818 & 949 & 1,051 & 1,189 & 1,514 & 1,820 \\
\hline
\end{tabular}




\section{A.2.-Continued}

B. Ten largest banks by assets

\begin{tabular}{|c|c|c|c|c|c|c|c|c|c|c|}
\hline Item & 1989 & 1990 & 1991 & 1992 & 1993 & 1994 & 1995 & 1996 & 1997 & 1998 \\
\hline & \multicolumn{10}{|c|}{ Effective interest rate (percent) ${ }^{3}$} \\
\hline \multicolumn{11}{|l|}{ Rates earned } \\
\hline Interest-earning assets . & 12.31 & 11.65 & 9.92 & 8.67 & 8.16 & 8.15 & 8.20 & 7.72 & 7.55 & 7.54 \\
\hline Taxable equivalent .. & 12.31 & 11.70 & 9.95 & 8.72 & 8.20 & 8.18 & 8.22 & 7.74 & 7.60 & 7.57 \\
\hline Loans and leases, gross ... & 13.19 & 12.29 & 10.46 & 9.36 & 9.07 & 8.89 & 8.84 & 8.32 & 8.25 & 8.21 \\
\hline Net of loss provisions ... & 10.87 & 11.10 & 8.58 & 7.51 & 7.95 & 8.38 & 8.62 & 8.11 & 7.93 & 7.62 \\
\hline Securities $\ldots \ldots \ldots \ldots \ldots \ldots$ & 10.11 & 9.85 & 8.52 & 7.38 & 6.69 & 7.09 & 7.41 & 6.80 & 6.70 & 6.79 \\
\hline Taxable equivalent & 10.08 & 10.00 & 8.63 & 7.54 & 6.77 & 7.19 & 7.47 & 6.85 & 6.85 & 6.89 \\
\hline Investment account $\ldots \ldots \ldots \ldots \ldots$ & 9.20 & 9.34 & 8.99 & 7.96 & 6.90 & 6.57 & 7.06 & 6.71 & 6.61 & 6.71 \\
\hline U.S. government and other debt & 9.60 & 9.68 & 9.29 & 8.13 & 6.99 & 6.70 & 7.22 & 6.86 & 6.80 & 6.92 \\
\hline State and local $\ldots \ldots \ldots \ldots \ldots$ & 7.69 & 7.54 & 7.67 & 7.40 & 6.99 & 6.35 & 6.23 & 5.73 & 5.55 & 5.50 \\
\hline Equity $\ldots \ldots \ldots$ & 7.03 & 5.82 & 4.22 & 4.04 & 3.72 & 3.27 & 4.03 & 3.84 & 3.47 & 2.98 \\
\hline Trading account $\ldots \ldots \ldots \ldots \ldots \ldots \ldots$ & 12.13 & 10.75 & 7.84 & 6.69 & 6.45 & 7.79 & 7.83 & 6.90 & 6.81 & 6.92 \\
\hline Gross federal funds sold and reverse RPs & 8.98 & 8.01 & 5.60 & 3.65 & 3.02 & 4.52 & 5.20 & 4.92 & 5.45 & 5.20 \\
\hline Interest-bearing balances at depositories .. & 10.88 & 11.06 & 10.05 & 9.29 & 8.34 & 7.27 & 7.15 & 6.71 & 6.91 & 7.16 \\
\hline \multicolumn{11}{|l|}{ Rates paid } \\
\hline Interest-bearing liabilities. & 10.74 & 10.18 & 7.71 & 6.17 & 5.60 & 5.43 & 5.88 & 5.44 & 5.41 & 5.29 \\
\hline Interest-bearing deposits & 9.19 & 9.03 & 7.09 & 5.33 & 4.50 & 4.32 & 4.99 & 4.57 & 4.54 & 4.40 \\
\hline In foreign offices .... & 10.96 & 11.11 & 8.76 & 7.55 & 6.87 & 6.04 & 6.07 & 5.62 & 5.52 & 5.83 \\
\hline In domestic offices $\ldots \ldots \ldots$. & 7.28 & 6.81 & 5.47 & 3.25 & 2.36 & 2.35 & 3.42 & 3.32 & 3.69 & 3.39 \\
\hline Other checkable deposits & 4.40 & 4.35 & 3.93 & 1.97 & 1.28 & 1.10 & 1.29 & 1.32 & 1.97 & 1.67 \\
\hline Savings (including MMDAs). & 6.49 & 6.21 & 5.09 & 2.95 & 2.14 & 2.35 & 3.11 & 2.76 & 2.68 & 2.45 \\
\hline Large-denomination time deposits ${ }^{4}$ & 8.87 & 7.96 & 6.50 & 4.66 & 3.55 & 3.12 & 3.73 & 4.62 & 5.17 & 4.53 \\
\hline Small-denomination time deposits ${ }^{4}$. & 8.26 & 7.76 & 6.09 & 3.81 & 3.01 & 2.80 & 5.08 & 4.58 & 5.45 & 5.21 \\
\hline Gross federal funds purchased and RPs $\ldots \ldots$. & 9.27 & 7.75 & 5.98 & 4.04 & 3.26 & 4.05 & 5.22 & 4.93 & 5.02 & 5.18 \\
\hline \multirow[t]{2}{*}{ Other interest-bearing liabilities $\ldots \ldots \ldots \ldots \ldots$} & 19.31 & 17.27 & 11.20 & 10.40 & 11.16 & 10.87 & 9.80 & 8.86 & 9.13 & 8.85 \\
\hline & \multicolumn{10}{|c|}{ Income and expense as a percentage of average net consolidated assets } \\
\hline Gross interest income. & 10.82 & 10.37 & 8.77 & 7.69 & 7.22 & 6.37 & 6.42 & 6.26 & 6.31 & 6.21 \\
\hline Taxable equivalent & 10.83 & 10.43 & 8.80 & 7.72 & 7.25 & 6.40 & 6.43 & 6.27 & 6.33 & 6.23 \\
\hline Loans $\ldots \ldots \ldots \ldots \ldots$ & 8.23 & 7.96 & 6.77 & 5.65 & 5.22 & 4.49 & 4.44 & 4.48 & 4.31 & 4.27 \\
\hline Securities $\ldots \ldots \ldots \ldots \ldots \ldots \ldots \ldots \ldots$ & .83 & .86 & .84 & .85 & .86 & .77 & .75 & .71 & .73 & .81 \\
\hline Gross federal funds sold and reverse RPs & .37 & .25 & .17 & .14 & .11 & .15 & .21 & .18 & .45 & .42 \\
\hline Other $\ldots \ldots \ldots \ldots \ldots \ldots \ldots \ldots \ldots \ldots \ldots \ldots \ldots$ & 1.39 & 1.30 & .98 & 1.05 & 1.04 & .97 & 1.00 & .88 & .82 & .70 \\
\hline Gross interest expense & 8.01 & 7.65 & 5.81 & 4.54 & 4.06 & 3.52 & 3.74 & 3.52 & 3.55 & 3.48 \\
\hline Deposits $\ldots \ldots \ldots \ldots \ldots \ldots \ldots \ldots \ldots$ & 5.37 & 5.41 & 4.23 & 3.09 & 2.48 & 2.15 & 2.43 & 2.26 & 2.26 & 2.20 \\
\hline Gross federal funds purchased and RPs & .72 & .64 & .43 & .28 & .24 & .24 & .35 & .31 & .54 & .54 \\
\hline Other $\ldots \ldots \ldots \ldots \ldots \ldots \ldots \ldots \ldots \ldots \ldots \ldots \ldots$ & 1.92 & 1.60 & 1.15 & 1.17 & 1.35 & 1.13 & .95 & .95 & .75 & .74 \\
\hline Net interest income.... & 2.82 & 2.72 & 2.96 & 3.15 & 3.16 & 2.86 & 2.68 & 2.73 & 2.76 & 2.73 \\
\hline Taxable equivalent & 2.82 & 2.77 & 2.99 & 3.18 & 3.19 & 2.88 & 2.70 & 2.75 & 2.79 & 2.75 \\
\hline Loss provisioning 5 & 1.45 & .77 & 1.21 & 1.12 & .64 & .26 & .11 & .11 & .16 & .31 \\
\hline Noninterest income $\ldots \ldots \ldots \ldots$ & 2.19 & 2.27 & 2.40 & 2.59 & 2.99 & 2.33 & 2.16 & 2.34 & 2.12 & 2.15 \\
\hline Service charges on deposits $\ldots$. & .22 & .23 & .26 & .30 & .30 & .26 & .25 & .28 & .32 & .33 \\
\hline Income from fiduciary activities...... & .27 & .31 & .33 & .37 & .39 & .36 & .30 & .31 & .34 & .32 \\
\hline Trading income $\ldots \ldots \ldots \ldots \ldots \ldots \ldots$ & .42 & .52 & .64 & .66 & .91 & .53 & .46 & .52 & .43 & .33 \\
\hline Interest rate exposures $\ldots \ldots \ldots \ldots \ldots$ & n.a. & n.a. & n.a. & n.a. & n.a. & n.a. & n.a. & .30 & .23 & .10 \\
\hline Foreign exchange exposures $\ldots \ldots \ldots \ldots \ldots$ & n.a. & n.a. & n.a. & n.a. & n.a. & n.a. & n.a. & .17 & .20 & .20 \\
\hline Equity, commodity, and other exposures .... & n.a. & n.a. & n.a. & n.a. & n.a. & n.a. & n.a. & .05 & $*$ & .03 \\
\hline 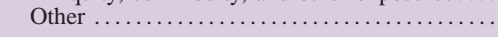 & 1.29 & 1.21 & 1.16 & 1.27 & 1.38 & 1.18 & 1.15 & 1.23 & 1.04 & 1.17 \\
\hline Noninterest expense $\ldots \ldots \ldots \ldots \ldots \ldots \ldots$ & 3.43 & 3.55 & 3.83 & 3.86 & 4.13 & 3.56 & 3.32 & 3.57 & 3.24 & 3.47 \\
\hline Salaries, wages, and employee benefits & 1.66 & 1.74 & 1.79 & 1.78 & 1.88 & 1.65 & 1.58 & 1.57 & 1.45 & 1.45 \\
\hline Expenses of premises and fixed assets. & .62 & .65 & .66 & .65 & .66 & .55 & .50 & .50 & .47 & .47 \\
\hline Other $\ldots \ldots \ldots \ldots \ldots \ldots \ldots \ldots \ldots \ldots \ldots$ & 1.15 & 1.16 & 1.38 & 1.43 & 1.59 & 1.36 & 1.24 & 1.50 & 1.33 & 1.54 \\
\hline Net noninterest expense . & 1.24 & 1.28 & 1.44 & 1.27 & 1.14 & 1.23 & 1.16 & 1.23 & 1.12 & 1.32 \\
\hline Realized gains on investment account securities & .03 & .02 & .04 & .11 & .13 & .02 & .03 & .04 & .08 & .11 \\
\hline Income before taxes and extraordinary items .... & .16 & 69 & .34 & .87 & 1.50 & 1.39 & 1.44 & 1.44 & 1.56 & 1.22 \\
\hline 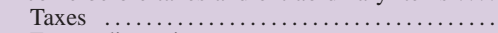 & .38 & .27 & .17 & .26 & .53 & .48 & .55 & .52 & .58 & .44 \\
\hline Extraordinary items $\ldots \ldots \ldots$ & .03 & .06 & .03 & * & .16 & * & $*$ & $*$ & $*$ & $*$ \\
\hline Net income (return on assets) & -.19 & .48 & .21 & .61 & 1.13 & .91 & .88 & .92 & .98 & .78 \\
\hline Cash dividends declared ... & .37 & .26 & .21 & .18 & .28 & .58 & .57 & .70 & .82 & .53 \\
\hline Retained income ........ & -.57 & .21 & $*$ & .43 & .85 & .33 & .31 & .21 & .15 & .25 \\
\hline Meмо: Return on equity & -3.92 & 10.13 & 4.23 & 10.91 & 16.75 & 13.86 & 13.78 & 13.21 & 13.22 & 10.53 \\
\hline
\end{tabular}

* In absolute value, less than 0.005 percent.

Definitions. n.a. Not available. MMDA Money market deposit account. RP Repurchase agreement. CD Certificate of deposit.

1. Includes the allowance for loan and lease losses and the allocated transfer risk reserve.

2. Before 1994, the netted value of off-balance-sheet items appeared in "trading account securities"

if a gain and "other non-interest-bearing liabilities" if a loss.

3. When possible, based on the average of quarterly balance sheet data reported on schedule RC-K of the quarterly Call Reports

4. Before 1997, data for large time open accounts are included in small-denomination time deposits.

5. Includes provisions for loan and lease losses and for allocated transfer risk. 
A.2. Portfolio composition, interest rates, and income and expense, all U.S. banks, 1989-98 C. Banks ranked 11th through 100th by assets

\begin{tabular}{|c|c|c|c|c|c|c|c|c|c|c|}
\hline Item & 1989 & 1990 & 1991 & 1992 & 1993 & 1994 & 1995 & 1996 & 1997 & 1998 \\
\hline & \multicolumn{10}{|c|}{ Balance sheet items as a percentage of average net consolidated assets } \\
\hline Interest-earning assets . & 86.91 & 86.81 & 86.88 & 87.97 & 88.36 & 88.16 & 88.31 & 87.75 & 86.95 & 87.40 \\
\hline Loans and leases, net $\ldots . .$. & 62.61 & 61.22 & 60.08 & 58.30 & 57.33 & 58.56 & 62.68 & 64.24 & 63.89 & 64.40 \\
\hline Commercial and industrial & 22.75 & 21.76 & 20.53 & 18.83 & 18.03 & 18.03 & 19.26 & 18.95 & 19.01 & 18.94 \\
\hline U.S. addressees ......... & 21.23 & 20.44 & 19.30 & 17.78 & 17.05 & 16.99 & 18.10 & 17.71 & 17.78 & 17.60 \\
\hline Foreign addressees & 1.53 & 1.33 & 1.24 & 1.05 & .98 & 1.04 & 1.16 & 1.24 & 1.22 & 1.33 \\
\hline Consumer ........... & 12.97 & 12.25 & 11.66 & 11.72 & 11.47 & 12.62 & 14.23 & 15.67 & 15.62 & 14.52 \\
\hline Credit card .......... & 5.82 & 5.48 & 5.04 & 5.16 & 5.23 & 5.99 & 7.34 & 8.26 & 8.50 & 7.67 \\
\hline Installment and other & 7.16 & 6.76 & 6.62 & 6.56 & 6.24 & 6.63 & 6.89 & 7.40 & 7.12 & 6.85 \\
\hline Real estate ........... & 19.09 & 20.21 & 21.51 & 21.89 & 22.11 & 22.26 & 23.25 & 23.26 & 22.99 & 24.57 \\
\hline In domestic offices & 18.85 & 20.04 & 21.37 & 21.78 & 22.01 & 22.17 & 23.10 & 23.10 & 22.85 & 24.39 \\
\hline Construction and land development & 5.25 & 4.91 & 4.00 & 3.02 & 2.08 & 1.63 & 1.50 & 1.55 & 1.69 & 2.02 \\
\hline Farmland $\ldots \ldots \ldots \ldots \ldots \ldots \ldots \ldots$ & .12 & .12 & .12 & .14 & .13 & .14 & .13 & .13 & .14 & .17 \\
\hline One- to four-family residential ..... & 7.54 & 8.53 & 10.17 & 11.36 & 12.30 & 12.98 & 14.16 & 14.15 & 13.88 & 14.84 \\
\hline Home equity $\ldots \ldots \ldots \ldots \ldots$ & 1.41 & 1.67 & 2.07 & 2.50 & 2.54 & 2.33 & 2.19 & 2.08 & 2.22 & 2.17 \\
\hline Other $\ldots \ldots \ldots \ldots$ & 6.13 & 6.86 & 8.10 & 8.85 & 9.76 & 10.65 & 11.97 & 12.07 & 11.65 & 12.67 \\
\hline Multifamily residential & .45 & .46 & .54 & .66 & .71 & .71 & .77 & .89 & .93 & 1.00 \\
\hline Nonfarm nonresidential & 5.49 & 6.01 & 6.53 & 6.61 & 6.79 & 6.72 & 6.54 & 6.37 & 6.21 & 6.35 \\
\hline In foreign offices ........ & .24 & .18 & .14 & .11 & .10 & .09 & .15 & .16 & .15 & .18 \\
\hline Depository institutions & 1.55 & 1.57 & 1.58 & 1.43 & 1.30 & 1.49 & 1.59 & 1.50 & 1.27 & 1.06 \\
\hline Foreign governments. & .88 & .52 & .39 & .33 & .30 & .28 & .20 & .20 & .09 & .06 \\
\hline Agricultural production & .29 & .28 & .31 & .31 & .29 & .29 & .26 & .28 & .29 & .33 \\
\hline Other loans .............. & 5.17 & 4.82 & 4.55 & 4.28 & 4.05 & 3.47 & 3.32 & 3.30 & 3.21 & 3.38 \\
\hline Lease-financing receivables .... & 1.73 & 1.67 & 1.53 & 1.49 & 1.47 & 1.60 & 1.96 & 2.41 & 2.70 & 2.75 \\
\hline LESS: Unearned income on loans & -.34 & -.26 & -.22 & -.17 & -.11 & -.07 & -.07 & -.06 & -.05 & -.04 \\
\hline LEss: Loss reserves ${ }^{1} \ldots \ldots \ldots$ & -1.48 & -1.60 & -1.76 & -1.79 & -1.60 & -1.41 & -1.32 & -1.27 & -1.24 & -1.16 \\
\hline Securities ............. & 15.21 & 16.19 & 17.38 & 20.38 & 21.97 & 21.19 & 18.64 & 16.87 & 15.80 & 16.65 \\
\hline Investment account & 14.38 & 15.32 & 16.25 & 19.24 & 20.60 & 19.82 & 17.88 & 16.06 & 15.07 & 16.12 \\
\hline Debt $\ldots \ldots \ldots \ldots$ & 14.15 & 15.14 & 16.02 & 18.99 & 20.34 & 19.50 & 17.51 & 15.62 & 14.58 & 15.57 \\
\hline U.S. Treasury $\ldots \ldots \ldots \ldots$ & 4.10 & 3.42 & 3.78 & 5.88 & 7.05 & 6.85 & 4.82 & 3.34 & 2.81 & 2.24 \\
\hline \multicolumn{11}{|l|}{ U.S. government agency and } \\
\hline corporation obligations $\ldots \ldots \ldots$ & 5.01 & 7.42 & 8.43 & 9.26 & 9.55 & 9.28 & 9.40 & 9.12 & 8.98 & 9.93 \\
\hline Government-backed mortgage pools & 4.03 & 5.32 & 5.38 & 5.22 & 5.21 & 5.30 & 5.06 & 5.42 & 5.17 & 4.98 \\
\hline Collateralized mortgage obligations & n.a. & 1.56 & 2.48 & 3.54 & 3.71 & 3.07 & 2.82 & 2.16 & 2.13 & 2.82 \\
\hline Other $\ldots \ldots \ldots \ldots \ldots \ldots \ldots$ & .98 & .54 & .57 & .50 & .63 & .91 & 1.51 & 1.54 & 1.68 & 2.12 \\
\hline State and local government .... & 2.70 & 2.03 & 1.63 & 1.46 & 1.31 & 1.21 & 1.11 & .99 & .88 & .92 r -10 \\
\hline Private mortgage-backed securities & n.a. & n.a. & 1.09 & 1.05 & 1.06 & .93 & 1.02 & .96 & .73 & .96 \\
\hline Other $\ldots \ldots \ldots \ldots \ldots \ldots \ldots \ldots$ & 2.34 & 2.27 & 1.10 & 1.34 & 1.37 & 1.22 & 1.16 & 1.21 & 1.18 & 1.53 \\
\hline Equity .. & .23 & .18 & .22 & .25 & .26 & .32 & .37 & .44 & .49 & .55 \\
\hline Trading account $\ldots \ldots \ldots \ldots \ldots \ldots \ldots$ & .83 & $\begin{array}{l}.10 \\
.88\end{array}$ & 1.13 & 1.14 & 1.37 & 1.37 & .76 & .80 & .73 & .54 \\
\hline Gross federal funds sold and reverse RPs & 3.71 & 4.41 & 4.90 & 4.78 & 4.98 & 5.11 & 4.52 & 4.26 & 4.38 & 3.58 \\
\hline Interest-bearing balances at depositories .. & 5.38 & 4.98 & 4.51 & 4.52 & 4.08 & 3.30 & 2.47 & 2.38 & 2.88 & 2.77 \\
\hline 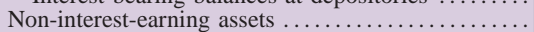 & 13.09 & 13.19 & 13.12 & 12.03 & 11.64 & 11.84 & 11.69 & 12.25 & 13.05 & 12.60 \\
\hline Revaluation gains on off-balance-sheet items $^{2}$ & n.a. & n.a. & n.a. & n.a. & n.a. & .57 & .50 & .51 & .69 & .75 \\
\hline Other $\ldots \ldots \ldots \ldots \ldots \ldots \ldots \ldots \ldots \ldots \ldots \ldots \ldots$ & 13.09 & 13.19 & 13.12 & 12.03 & 11.64 & 11.28 & 11.18 & 11.75 & 12.36 & 11.85 \\
\hline Liabilities..$\ldots \ldots \ldots \ldots \ldots$ & 94.45 & 94.35 & 93.93 & 93.13 & 92.56 & 92.47 & 92.23 & 92.02 & 91.85 & 91.63 \\
\hline Interest-bearing liabilities & 76.23 & 77.02 & 76.07 & 74.66 & 73.38 & 72.86 & 74.05 & 73.14 & 72.62 & 73.46 \\
\hline Deposits ............. & 56.45 & 57.46 & 59.24 & 56.99 & 54.22 & 53.03 & 52.32 & 51.81 & 51.47 & 51.52 \\
\hline In foreign offices & 8.63 & 7.84 & 6.69 & 6.20 & 6.78 & 8.05 & 8.12 & 7.52 & 7.85 & 8.16 \\
\hline In domestic offices $\ldots . . . .$. & 47.82 & 49.62 & 52.54 & 50.79 & 47.43 & 44.98 & 44.20 & 44.30 & 43.62 & 43.36 \\
\hline Other checkable deposits ... & 4.67 & 4.75 & 5.36 & 6.26 & 7.21 & 6.91 & 5.62 & 3.06 & 1.95 & 1.75 \\
\hline Savings (including MMDAs) $\ldots \ldots$ & 14.58 & 15.50 & 17.62 & 20.21 & 20.60 & 20.13 & 18.78 & 20.76 & 21.09 & 21.42 \\
\hline Small-denomination time deposits .. & 13.49 & 15.59 & 17.99 & 15.98 & 14.19 & 13.26 & 14.24 & 14.09 & 13.43 & 12.83 \\
\hline Large-denomination time deposits & 15.08 & 13.78 & 11.56 & 8.34 & 5.44 & 4.68 & 5.55 & 6.39 & 7.15 & 7.36 \\
\hline Gross federal funds purchased and RPs & 13.22 & 13.03 & 10.94 & 11.45 & 11.93 & 11.48 & 11.37 & 10.00 & 9.36 & 9.48 \\
\hline Other $\ldots \ldots \ldots \ldots \ldots \ldots \ldots \ldots \ldots \ldots \ldots \ldots \ldots \ldots \ldots \ldots \ldots \ldots$ & 6.57 & 6.53 & 5.89 & 6.22 & 7.23 & 8.34 & 10.36 & 11.32 & 11.79 & 12.46 \\
\hline Non-interest-bearing liabilities $\ldots \ldots \ldots \ldots \ldots$ & 18.22 & 17.33 & 17.87 & 18.47 & 19.18 & 19.62 & 18.18 & 18.89 & 19.22 & 18.17 \\
\hline Demand deposits in domestic offices ........... & 13.86 & 13.23 & 13.76 & 14.52 & 15.38 & 15.27 & 14.26 & 14.47 & 14.17 & 12.41 \\
\hline Revaluation losses on off-balance-sheet items ${ }^{2}$ & n.a. & n.a. & n.a. & n.a. & n.a. & .53 & .49 & .49 & .68 & .76 \\
\hline 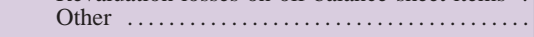 & 4.36 & 4.10 & 4.10 & 3.95 & 3.80 & 3.82 & 3.43 & 3.93 & 4.37 & 5.01 \\
\hline Capital account & 5.55 & 5.65 & 6.07 & 6.87 & 7.44 & 7.53 & 7.77 & 7.98 & 8.15 & 8.37 \\
\hline \multicolumn{11}{|l|}{ Мемо } \\
\hline Commercial real estate loans & n.a. & n.a. & 11.83 & 11.09 & 10.29 & 9.69 & 9.42 & 9.38 & 9.44 & 10.09 \\
\hline Other real estate owned ..... & .30 & .46 & .76 & .70 & .47 & .25 & .13 & .08 & .06 & .04 \\
\hline Managed liabilities.......... & 43.90 & 41.59 & 35.49 & 32.59 & 31.76 & 32.89 & 35.68 & 35.60 & 36.60 & 38.14 \\
\hline $\begin{array}{l}\text { Average net consolidated assets } \\
\text { (billions of dollars) } \ldots . \ldots \ldots\end{array}$ & 940 & 995 & 1,006 & 1,003 & 1,082 & 1,204 & 1,338 & 1,450 & 1,604 & 1,746 \\
\hline
\end{tabular}




\section{A.2.-Continued}

C. Banks ranked 11th through 100th by assets

\begin{tabular}{|c|c|c|c|c|c|c|c|c|c|c|}
\hline Item & 1989 & 1990 & 1991 & 1992 & 1993 & 1994 & 1995 & 1996 & 1997 & 1998 \\
\hline & \multicolumn{10}{|c|}{ Effective interest rate (percent) ${ }^{3}$} \\
\hline \multicolumn{11}{|l|}{ Rates earned } \\
\hline Interest-earning assets . & 11.10 & 10.46 & 9.30 & 7.97 & 7.35 & 7.29 & 8.31 & 8.16 & 8.31 & 8.10 \\
\hline Taxable equivalent ... & 11.27 & 10.55 & 9.39 & 8.07 & 7.45 & 7.37 & 8.37 & 8.23 & 8.36 & 8.16 \\
\hline Loans and leases, gross $\ldots$ & 11.74 & 11.09 & 9.96 & 8.75 & 8.25 & 8.22 & 9.10 & 8.87 & 9.03 & 8.82 \\
\hline Net of loss provisions & 9.87 & 9.08 & 7.98 & 7.45 & 7.46 & 7.68 & 8.49 & 8.05 & 8.11 & 8.01 \\
\hline Securities ............... & 8.76 & 8.86 & 8.23 & 7.00 & 6.05 & 5.70 & 6.38 & 6.42 & 6.50 & 6.21 \\
\hline Taxable equivalent & 9.36 & 9.18 & 8.57 & 7.30 & 6.32 & 5.92 & 6.56 & 6.66 & 6.70 & 6.46 \\
\hline Investment account & 8.77 & 8.92 & 8.37 & 7.12 & 6.14 & 5.70 & 6.34 & 6.41 & 6.52 & 6.22 \\
\hline U.S. government and other debt & 9.09 & 9.18 & 8.51 & 7.16 & 6.14 & 5.69 & 6.38 & 6.50 & 6.63 & 6.31 \\
\hline State and local $\ldots \ldots \ldots \ldots \ldots$ & 7.41 & 7.32 & 7.23 & 6.80 & 6.30 & 6.04 & 6.05 & 5.84 & 5.58 & 5.36 \\
\hline Equity ......... & 8.73 & 8.09 & 7.36 & 6.71 & 5.20 & 5.00 & 5.68 & 4.84 & 5.07 & 5.26 \\
\hline Trading account $\ldots \ldots \ldots \ldots \ldots \ldots$ & 8.66 & 8.01 & 6.46 & 4.73 & 4.74 & 5.75 & 7.27 & 6.53 & 6.05 & 5.86 \\
\hline Gross federal funds sold and reverse RPs & 9.35 & 8.15 & 5.80 & 3.70 & 3.11 & 4.31 & 5.91 & 5.31 & 5.45 & 5.47 \\
\hline Interest-bearing balances at depositories ... & 11.35 & 9.72 & 8.15 & 6.76 & 6.50 & 4.69 & 6.78 & 5.82 & 5.77 & 5.57 \\
\hline \multicolumn{11}{|l|}{ Rates paid } \\
\hline Interest-bearing liabilities. & 8.66 & 7.96 & 6.41 & 4.43 & 3.76 & 3.72 & 4.94 & 4.70 & 4.79 & 4.76 \\
\hline Interest-bearing deposits & 8.14 & 7.55 & 6.27 & 4.30 & 3.51 & 3.25 & 4.35 & 4.15 & 4.22 & 4.15 \\
\hline In foreign offices $\ldots .$. & 11.08 & 10.08 & 8.39 & 7.26 & 7.37 & 4.60 & 6.30 & 5.29 & 5.23 & 5.22 \\
\hline In domestic offices .. & 7.61 & 7.15 & 6.01 & 3.96 & 2.98 & 3.03 & 4.01 & 3.96 & 4.04 & 3.96 \\
\hline Other checkable deposits & 4.57 & 4.67 & 4.21 & 2.43 & 1.70 & 1.62 & 1.89 & 1.78 & 2.01 & 2.41 \\
\hline Savings (including MMDAs) ...... & 6.42 & 6.07 & 5.04 & 3.07 & 2.33 & 2.46 & 3.10 & 2.91 & 2.84 & 2.77 \\
\hline Large-denomination time deposits ${ }^{4}$ & 8.75 & 8.11 & 6.77 & 5.10 & 4.30 & 4.21 & 5.70 & 5.50 & 5.47 & 5.32 \\
\hline Small-denomination time deposits 4 & 8.72 & 8.09 & 6.96 & 5.07 & 4.06 & 4.18 & 5.35 & 5.26 & 5.43 & 5.33 \\
\hline Gross federal funds purchased and RPs & 9.35 & 8.12 & 5.75 & 3.57 & 3.04 & 4.28 & 5.86 & 5.19 & 5.29 & 5.23 \\
\hline Other interest-bearing liabilities ............ & 10.23 & 9.27 & 6.55 & 5.77 & 5.97 & 5.24 & 6.43 & 5.95 & 5.85 & 5.80 \\
\hline & \multicolumn{10}{|c|}{ Income and expense as a percentage of average net consolidated assets } \\
\hline Gross interest income .. & 9.77 & 9.31 & 8.24 & 7.12 & 6.58 & 6.46 & 7.40 & 7.24 & 7.26 & 7.16 \\
\hline Taxable equivalent & 9.91 & 9.39 & 8.31 & 7.19 & 6.64 & 6.51 & 7.45 & 7.28 & 7.30 & 7.20 \\
\hline Loans............. & 7.51 & 7.01 & 6.15 & 5.23 & 4.84 & 4.91 & 5.79 & 5.80 & 5.87 & 5.79 \\
\hline 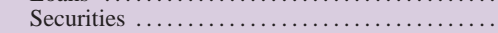 & 1.26 & 1.37 & 1.36 & 1.37 & 1.26 & 1.13 & 1.13 & 1.03 & .98 & 1.00 \\
\hline Gross federal funds sold and reverse RPs & .36 & .38 & .28 & .18 & .15 & .21 & .27 & .23 & .22 & .19 \\
\hline Other $\ldots \ldots \ldots \ldots \ldots \ldots \ldots \ldots \ldots \ldots \ldots \ldots$ & .65 & .56 & .45 & .34 & .32 & .21 & .21 & .18 & .19 & .18 \\
\hline Gross interest expense & 6.50 & 6.08 & 4.80 & 3.26 & 2.74 & 2.67 & 3.62 & 3.39 & 3.41 & 3.45 \\
\hline 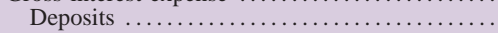 & 4.59 & 4.36 & 3.75 & 2.48 & 1.93 & 1.73 & 2.29 & 2.18 & 2.23 & 2.23 \\
\hline Gross federal funds purchased and RPs & 1.24 & 1.12 & .67 & .43 & .38 & .51 & .67 & .55 & .51 & .51 \\
\hline Other $\ldots \ldots \ldots \ldots \ldots \ldots \ldots \ldots \ldots \ldots \ldots \ldots \ldots$ & .66 & .60 & .38 & .35 & .43 & .43 & .66 & .66 & .68 & .71 \\
\hline Net interest income .... & 3.27 & 3.23 & 3.43 & 3.86 & 3.84 & 3.79 & 3.78 & 3.84 & 3.85 & 3.71 \\
\hline Taxable equivalent & 3.41 & 3.31 & 3.51 & 3.93 & 3.91 & 3.85 & 3.84 & 3.89 & 3.89 & 3.74 \\
\hline Loss provisioning 5 & 1.20 & 1.27 & 1.22 & .78 & .47 & .32 & .39 & .54 & .60 & .53 \\
\hline Noninterest income .......... & 1.86 & 1.84 & 2.05 & 2.25 & 2.29 & 2.25 & 2.38 & 2.61 & 2.76 & 3.07 \\
\hline Service charges on deposits .... & .31 & .34 & .41 & .44 & .46 & .45 & .44 & .44 & .44 & .42 \\
\hline Income from fiduciary activities $\ldots . \ldots \ldots \ldots$ & .35 & .33 & .36 & .38 & .38 & .39 & .40 & .43 & .44 & .49 \\
\hline Trading income $\ldots \ldots \ldots \ldots \ldots \ldots \ldots \ldots$ & .08 & .08 & .10 & .09 & .14 & .08 & .09 & .08 & .08 & .09 \\
\hline Interest rate exposures $\ldots \ldots \ldots \ldots \ldots$ & n.a. & n.a. & n.a. & n.a. & n.a. & n.a. & n.a. & .03 & .02 & .03 \\
\hline Foreign exchange exposures $\ldots \ldots \ldots \ldots \ldots$ & n.a. & n.a. & n.a. & n.a. & n.a. & n.a. & n.a. & .04 & .05 & .06 \\
\hline Equity, commodity, and other exposures... & n.a. & n.a. & n.a. & n.a. & n.a. & n.a. & n.a. & .01 & $*$ & $*$ \\
\hline 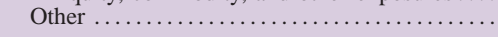 & 1.12 & 1.09 & 1.19 & 1.33 & 1.32 & 1.33 & 1.45 & 1.67 & 1.79 & 2.07 \\
\hline Noninterest expense $\ldots \ldots \ldots \ldots \ldots \ldots \ldots$ & 3.34 & 3.44 & 3.77 & 3.98 & 3.95 & 3.86 & 3.79 & 3.85 & 3.85 & 4.03 \\
\hline Salaries, wages, and employee benefits & 1.47 & 1.47 & 1.52 & 1.53 & 1.52 & 1.50 & 1.47 & 1.51 & 1.51 & 1.53 \\
\hline Expenses of premises and fixed assets & .50 & .50 & .51 & .49 & .47 & .47 & .47 & .48 & .46 & .46 \\
\hline Other $\ldots \ldots \ldots \ldots \ldots \ldots \ldots \ldots \ldots \ldots$ & 1.37 & 1.48 & 1.74 & 1.95 & 1.95 & 1.89 & 1.85 & 1.86 & 1.88 & 2.04 \\
\hline Net noninterest expense $\ldots \ldots \ldots \ldots \ldots \ldots \ldots$ & 1.47 & 1.60 & 1.73 & 1.73 & 1.65 & 1.61 & 1.41 & 1.24 & 1.10 & .96 \\
\hline Realized gains on investment account securities & .04 & .03 & .14 & .15 & .09 & -.01 & .02 & .02 & .02 & .03 \\
\hline Income before taxes and extraordinary items ... & .65 & .38 & .62 & 1.50 & 1.81 & 1.85 & 2.01 & 2.09 & 2.18 & 2.24 \\
\hline Taxes $\ldots \ldots \ldots \ldots \ldots$ & .18 & .15 & .19 & .48 & .56 & .63 & .70 & .75 & .77 & .79 \\
\hline Extraordinary items $\ldots \ldots \ldots \ldots \ldots \ldots \ldots$ & $*$ & .01 & .03 & .03 & $*$ & $*$ & $*$ & $*$ & $*$ & $*$ \\
\hline Net income (return on assets) & .47 & .24 & .47 & 1.04 & 1.25 & 1.22 & 1.31 & 1.34 & 1.42 & 1.46 \\
\hline Cash dividends declared ... & .40 & .38 & .47 & .46 & .76 & .86 & .85 & 1.07 & .93 & .96 \\
\hline Retained income .......... & .06 & -.14 & $*$ & .58 & .49 & .36 & .46 & .26 & .48 & .50 \\
\hline Мемо: Return on equity ... & 8.41 & 4.18 & 7.71 & 15.16 & 16.86 & 16.27 & 16.84 & 16.78 & 17.36 & 17.42 \\
\hline
\end{tabular}

* In absolute value, less than 0.005 percent.

Definitions. n.a. Not available. MMDA Money market deposit account. RP Repurchase agreement. CD Certificate of deposit.

1. Includes the allowance for loan and lease losses and the allocated transfer risk reserve.

2. Before 1994, the netted value of off-balance-sheet items appeared in "trading account securities"

if a gain and "other non-interest-bearing liabilities" if a loss.

3. When possible, based on the average of quarterly balance sheet data reported on schedule RC-K of the quarterly Call Reports.

4. Before 1997, data for large time open accounts are included in small-denomination time deposits.

5. Includes provisions for loan and lease losses and for allocated transfer risk. 
A.2. Portfolio composition, interest rates, and income and expense, all U.S. banks, 1989-98 D. Banks ranked 101st through 1,000th by assets

\begin{tabular}{|c|c|c|c|c|c|c|c|c|c|c|}
\hline Item & 1989 & 1990 & 1991 & 1992 & 1993 & 1994 & 1995 & 1996 & 1997 & 1998 \\
\hline & \multicolumn{10}{|c|}{ Balance sheet items as a percentage of average net consolidated assets } \\
\hline Interest-earning assets . & 88.98 & 88.84 & 88.91 & 89.02 & 89.55 & 90.09 & 90.12 & 90.13 & 90.31 & 90.38 \\
\hline Loans and leases, net & 63.62 & 63.09 & 61.03 & 58.49 & 57.94 & 59.75 & 62.18 & 62.63 & 62.21 & 61.12 \\
\hline Commercial and industrial & 17.68 & 16.69 & 15.04 & 13.34 & 12.19 & 12.07 & 12.70 & 12.79 & 12.43 & 12.45 \\
\hline U.S. addressees ......... & 17.53 & 16.56 & 14.88 & 13.16 & 12.03 & 11.90 & 12.54 & 12.61 & 12.20 & 12.13 \\
\hline Foreign addressees $\ldots . .$. & .15 & .13 & .16 & .18 & .16 & .16 & .16 & .18 & .23 & .32 \\
\hline Consumer ........... & 15.49 & 15.48 & 15.13 & 14.18 & 14.83 & 15.85 & 16.25 & 15.88 & 13.99 & 12.29 \\
\hline Credit card .......... & 4.83 & 5.22 & 5.74 & 5.37 & 5.63 & 6.06 & 6.30 & 6.66 & 5.48 & 4.48 \\
\hline Installment and other & 10.66 & 10.26 & 9.39 & 8.80 & 9.20 & 9.79 & 9.95 & 9.22 & 8.51 & 7.81 \\
\hline Real estate ........... & 25.97 & 27.01 & 27.51 & 28.11 & 28.61 & 29.42 & 30.82 & 31.37 & 33.26 & 33.97 \\
\hline In domestic offices & 25.95 & 26.99 & 27.47 & 28.07 & 28.59 & 29.39 & 30.80 & 31.35 & 33.23 & 33.95 \\
\hline Construction and land development & 4.82 & 4.37 & 3.66 & 2.86 & 2.26 & 2.08 & 2.21 & 2.38 & 2.69 & 2.89 \\
\hline Farmland $\ldots \ldots \ldots \ldots \ldots \ldots \ldots \ldots$ & .27 & .28 & .28 & .32 & .34 & .36 & .40 & .46 & .53 & .56 \\
\hline One- to four-family residential ... & 11.56 & 12.49 & 13.22 & 14.26 & 15.17 & 16.24 & 17.49 & 17.34 & 18.16 & 18.21 \\
\hline Home equity..$\ldots \ldots \ldots \ldots$ & 2.08 & 2.31 & 2.53 & 2.56 & 2.50 & 2.33 & 2.36 & 2.31 & 2.30 & 2.15 \\
\hline Other $\ldots \ldots \ldots \ldots$ & 9.48 & 10.18 & 10.69 & 11.69 & 12.67 & 13.91 & 15.13 & 15.04 & 15.85 & 16.06 \\
\hline Multifamily residential & .70 & .73 & .80 & .96 & 1.07 & 1.13 & 1.21 & 1.29 & 1.29 & 1.26 \\
\hline Nonfarm nonresidential & 8.61 & 9.11 & 9.50 & 9.69 & 9.75 & 9.57 & 9.48 & 9.88 & 10.57 & 11.04 \\
\hline In foreign offices ......... & .01 & .03 & .05 & .04 & .02 & .03 & .02 & .02 & .02 & .02 \\
\hline Depository institutions & .92 & 1.05 & .93 & .80 & .43 & .40 & .35 & .48 & .57 & .50 \\
\hline Foreign governments .. & .16 & .09 & .07 & .05 & .03 & .02 & .02 & .02 & .02 & .02 \\
\hline Agricultural production & .45 & .47 & .49 & .54 & .56 & .62 & .69 & .71 & .74 & .80 \\
\hline Other loans .............. & 3.77 & 3.16 & 2.81 & 2.47 & 2.16 & 2.01 & 1.80 & 1.69 & 1.50 & 1.32 \\
\hline Lease-financing receivables .... & .82 & .83 & .85 & .79 & .77 & .83 & .90 & 1.01 & .99 & .98 \\
\hline LESS: Unearned income on loans & -.56 & -.50 & -.40 & -.30 & -.21 & -.15 & -.12 & -.10 & -.10 & -.09 \\
\hline LEss: Loss reserves ${ }^{1} \ldots \ldots \ldots \ldots$ & -1.07 & -1.20 & -1.42 & -1.49 & -1.44 & -1.30 & -1.22 & -1.22 & -1.18 & -1.13 \\
\hline Securities ............ & 18.75 & 19.34 & 21.28 & 24.13 & 25.92 & 25.71 & 23.09 & 22.67 & 23.47 & 24.28 \\
\hline Investment account & 18.38 & 18.87 & 20.91 & 23.78 & 25.64 & 25.40 & 22.89 & 22.55 & 23.36 & 24.17 \\
\hline Debt .............. & 18.02 & 18.54 & 20.55 & 23.32 & 25.16 & 24.95 & 22.43 & 22.03 & 22.75 & 23.48 \\
\hline U.S. Treasury $\ldots \ldots \ldots \ldots$ & 5.91 & 5.44 & 6.16 & 7.75 & 8.64 & 8.26 & 6.49 & 5.61 & 4.95 & 3.93 \\
\hline U.S. government agency and & & & & & & & & & & \\
\hline corporation obligations $\ldots \ldots \ldots$ & 6.07 & 7.75 & 9.35 & 11.08 & 12.32 & 12.67 & 12.23 & 12.66 & 13.98 & 15.13 \\
\hline Government-backed mortgage pools & 3.03 & 3.83 & 4.51 & 4.74 & 4.97 & 5.57 & 5.42 & 5.68 & 6.23 & 6.47 \\
\hline Collateralized mortgage obligations & n.a. & 1.72 & 2.73 & 3.95 & 4.82 & 4.39 & 3.56 & 3.12 & 3.02 & 3.23 \\
\hline Other $\ldots \ldots \ldots \ldots \ldots \ldots \ldots \ldots$ & 3.04 & 2.19 & 2.11 & 2.39 & 2.53 & 2.71 & 3.25 & 3.85 & 4.73 & 5.44 \\
\hline 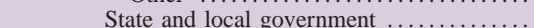 & 3.50 & 3.11 & 2.65 & 2.27 & 2.26 & 2.29 & 2.13 & 2.24 & 2.45 & 2.71 \\
\hline Private mortgage-backed securities & n.a. & n.a. & 1.16 & 1.01 & .84 & .75 & .68 & .76 & .59 & .65 \\
\hline Other $\ldots \ldots \ldots \ldots \ldots \ldots \ldots \ldots$ & 2.55 & 2.25 & 1.23 & 1.21 & 1.10 & .99 & .89 & .77 & .78 & 1.06 \\
\hline Equity $\ldots \ldots \ldots \ldots$ & .35 & .32 & .37 & .46 & .48 & 44 & .47 & .52 & .61 & .69 \\
\hline Trading account $\ldots \ldots \ldots \ldots \ldots \ldots \ldots$ & .38 & .48 & .36 & .35 & .28 & .31 & .20 & .12 & .10 & .11 \\
\hline Gross federal funds sold and reverse RPs & 4.11 & 4.51 & 4.71 & 4.92 & 4.48 & 3.64 & 3.91 & 3.87 & 3.59 & 4.17 \\
\hline Interest-bearing balances at depositories .. & 2.49 & 1.90 & 1.89 & 1.47 & 1.20 & .98 & .93 & .96 & 1.03 & .82 \\
\hline 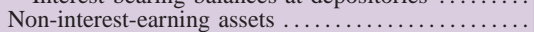 & 11.02 & 11.16 & 11.09 & 10.98 & 10.45 & 9.91 & 9.88 & 9.87 & 9.69 & 9.62 \\
\hline Revaluation gains on off-balance-sheet items ${ }^{2}$ & n.a. & n.a. & n.a. & n.a. & n.a. & .02 & .05 & .02 & $*$ & $*$ \\
\hline Other $\ldots \ldots \ldots \ldots \ldots \ldots \ldots \ldots \ldots \ldots \ldots \ldots \ldots \ldots \ldots$ & 11.02 & 11.16 & 11.09 & 10.98 & 10.45 & 9.90 & 9.83 & 9.84 & 9.69 & 9.61 \\
\hline Liabilities ............... & 93.28 & 93.07 & 92.89 & 92.47 & 91.85 & 91.62 & 91.36 & 91.06 & 90.79 & 90.54 \\
\hline Interest-bearing liabilities & 76.42 & 77.04 & 77.26 & 75.98 & 74.42 & 74.77 & 75.00 & 75.06 & 75.19 & 75.44 \\
\hline Deposits ............. & 63.74 & 65.05 & 66.35 & 65.65 & 63.05 & 60.38 & 59.69 & 59.99 & 61.51 & 62.45 \\
\hline In foreign offices & 2.09 & 1.65 & 1.76 & 1.56 & 1.43 & 1.69 & 1.71 & 1.33 & 1.23 & 1.29 \\
\hline In domestic offices ........ & 61.65 & 63.40 & 64.59 & 64.09 & 61.62 & 58.69 & 57.97 & 58.66 & 60.28 & 61.16 \\
\hline Other checkable deposits ... & 7.14 & 7.31 & 7.83 & 9.14 & 9.94 & 9.70 & 8.54 & 6.21 & 4.97 & 4.24 \\
\hline Savings (including MMDAs) ..... & 19.52 & 19.69 & 20.79 & 23.34 & 24.06 & 22.92 & 20.76 & 22.51 & 23.60 & 25.66 \\
\hline Small-denomination time deposits & 22.08 & 24.09 & 25.22 & 23.56 & 20.77 & 19.29 & 21.12 & 21.61 & 22.05 & 21.25 \\
\hline Large-denomination time deposits & 12.91 & 12.31 & 10.76 & 8.06 & 6.85 & 6.78 & 7.56 & 8.34 & 9.66 & 10.01 \\
\hline Gross federal funds purchased and RPs ... & 9.21 & 8.43 & 7.46 & 7.17 & 7.43 & 8.45 & 8.31 & 8.19 & 7.08 & 6.16 \\
\hline Other $\ldots \ldots \ldots \ldots \ldots \ldots \ldots \ldots \ldots \ldots \ldots \ldots$ & 3.47 & 3.56 & 3.45 & 3.15 & 3.93 & 5.94 & 7.00 & 6.88 & 6.59 & 6.83 \\
\hline Non-interest-bearing liabilities $\ldots \ldots \ldots \ldots \ldots \ldots$ & 16.85 & 16.03 & 15.63 & 16.49 & 17.43 & 16.85 & 16.36 & 16.00 & 15.60 & 15.10 \\
\hline Demand deposits in domestic offices .......... & 14.86 & 14.07 & 13.56 & 14.39 & 15.07 & 14.58 & 14.07 & 13.84 & 13.16 & 11.89 \\
\hline Revaluation losses on off-balance-sheet items ${ }^{2}$ & n.a. & n.a. & n.a. & n.a. & n.a. & .02 & .05 & .02 & .01 & .01 \\
\hline 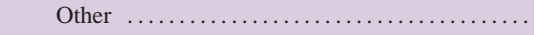 & 1.99 & 1.96 & 2.07 & 2.10 & 2.36 & 2.25 & 2.24 & 2.14 & 2.44 & 3.20 \\
\hline Capital account & 6.72 & 6.93 & 7.11 & 7.53 & 8.15 & 8.38 & 8.64 & 8.94 & 9.21 & 9.46 \\
\hline Мемо & & & & & & & & & & \\
\hline Commercial real estate loans & n.a. & n.a. & 14.63 & 13.91 & 13.37 & 13.05 & 13.20 & 13.84 & 14.79 & 15.40 \\
\hline Other real estate owned ..... & .43 & .52 & .77 & .80 & .57 & .28 & .17 & .13 & .11 & .09 \\
\hline Managed liabilities........... & 27.73 & 26.00 & 23.48 & 20.00 & 19.69 & 22.89 & 24.61 & 24.78 & 24.63 & 24.42 \\
\hline $\begin{array}{l}\text { Average net consolidated assets } \\
\text { (billions of dollars) } \ldots \ldots \ldots\end{array}$ & 892 & 937 & 962 & 968 & 977 & 1,032 & 1,092 & 1,076 & 967 & 935 \\
\hline
\end{tabular}




\section{A.2.-Continued}

D. Banks ranked 101st through 1,000th by assets

\begin{tabular}{|c|c|c|c|c|c|c|c|c|c|c|}
\hline Item & 1989 & 1990 & 1991 & 1992 & 1993 & 1994 & 1995 & 1996 & 1997 & 1998 \\
\hline & \multicolumn{10}{|c|}{ Effective interest rate (percent) ${ }^{3}$} \\
\hline \multicolumn{11}{|l|}{ Rates earned } \\
\hline Interest-earning assets . & 10.75 & 10.42 & 9.55 & 8.14 & 7.43 & 7.58 & 8.42 & 8.40 & 8.50 & 8.32 \\
\hline Taxable equivalent $\ldots$ & 10.96 & 10.57 & 9.70 & 8.25 & 7.55 & 7.68 & 8.51 & 8.49 & 8.59 & 8.44 \\
\hline Loans and leases, gross $\ldots$ & 11.61 & 11.21 & 10.43 & 9.11 & 8.57 & 8.64 & 9.43 & 9.38 & 9.48 & 9.37 \\
\hline Net of loss provisions & 10.45 & 9.48 & 8.72 & 7.83 & 7.76 & 8.11 & 8.76 & 8.59 & 8.60 & 8.61 \\
\hline Securities ............... & 8.34 & 8.52 & 8.11 & 6.88 & 5.78 & 5.69 & 6.23 & 6.31 & 6.42 & 6.22 \\
\hline Taxable equivalent & 8.97 & 9.00 & 8.54 & 7.19 & 6.10 & 5.93 & 6.49 & 6.59 & 6.69 & 6.57 \\
\hline Investment account & 8.35 & 8.49 & 8.12 & 6.90 & 5.79 & 5.69 & 6.24 & 6.31 & 6.42 & 6.22 \\
\hline U.S. government and other debt & 8.64 & 8.76 & 8.30 & 6.95 & 5.76 & 5.68 & 6.28 & 6.40 & 6.55 & 6.36 \\
\hline State and local $\ldots \ldots \ldots \ldots \ldots$ & 7.28 & 7.33 & 7.25 & 6.83 & 6.30 & 5.92 & 5.80 & 5.50 & 5.36 & 5.16 \\
\hline Equity ......... & 7.00 & 6.94 & 6.02 & 5.08 & 4.95 & 5.30 & 6.05 & 6.30 & 6.35 & 6.36 \\
\hline Trading account $\ldots \ldots \ldots \ldots \ldots \ldots$ & 7.61 & 9.92 & 7.19 & 5.61 & 4.74 & 5.29 & 5.55 & 5.94 & 6.37 & 6.48 \\
\hline Gross federal funds sold and reverse RPs & 9.05 & 7.99 & 5.64 & 3.47 & 3.02 & 4.06 & 5.45 & 5.24 & 5.41 & 5.30 \\
\hline Interest-bearing balances at depositories ... & 9.21 & 8.52 & 6.82 & 4.61 & 3.51 & 4.28 & 6.09 & 5.54 & 5.49 & 5.75 \\
\hline \multicolumn{11}{|l|}{ Rates paid } \\
\hline Interest-bearing liabilities. & 7.72 & 7.26 & 6.11 & 4.19 & 3.33 & 3.57 & 4.64 & 4.57 & 4.66 & 4.59 \\
\hline Interest-bearing deposits & 7.36 & 7.05 & 6.06 & 4.17 & 3.26 & 3.31 & 4.26 & 4.26 & 4.34 & 4.28 \\
\hline In foreign offices $\ldots .$. & 8.98 & 8.12 & 6.38 & 4.25 & 3.35 & 4.31 & 5.94 & 5.43 & 5.42 & 5.54 \\
\hline In domestic offices ........ & 7.31 & 7.02 & 6.05 & 4.17 & 3.25 & 3.28 & 4.21 & 4.23 & 4.32 & 4.26 \\
\hline Other checkable deposits & 4.88 & 4.75 & 4.28 & 2.67 & 2.02 & 1.87 & 2.02 & 1.96 & 2.17 & 2.16 \\
\hline Savings (including MMDAs) ...... & 6.13 & 5.98 & 5.14 & 3.33 & 2.58 & 2.64 & 3.24 & 3.11 & 3.08 & 2.97 \\
\hline Large-denomination time deposits ${ }^{4}$ & 8.70 & 8.04 & 6.64 & 4.76 & 3.90 & 4.23 & 5.62 & 5.47 & 5.56 & 5.50 \\
\hline Small-denomination time deposits 4 & 8.31 & 8.03 & 7.08 & 5.35 & 4.40 & 4.40 & 5.53 & 5.57 & 5.57 & 5.64 \\
\hline Gross federal funds purchased and RPs & 9.01 & 7.86 & 5.62 & 3.46 & 2.95 & 4.12 & 5.61 & 5.16 & 5.21 & 5.13 \\
\hline Other interest-bearing liabilities ............ & 9.08 & 8.28 & 6.78 & 5.28 & 4.44 & 4.92 & 6.27 & 5.89 & 6.12 & 6.00 \\
\hline & \multicolumn{10}{|c|}{ Income and expense as a percentage of average net consolidated assets } \\
\hline Gross interest income .. & 9.68 & 9.38 & 8.64 & 7.36 & 6.75 & 6.90 & 7.68 & 7.67 & 7.76 & 7.64 \\
\hline Taxable equivalent & 9.86 & 9.51 & 8.76 & 7.46 & 6.84 & 6.99 & 7.76 & 7.75 & 7.84 & 7.72 \\
\hline Loans ............... & 7.52 & 7.21 & 6.52 & 5.46 & 5.07 & 5.26 & 5.98 & 5.99 & 6.01 & 5.86 \\
\hline 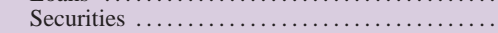 & 1.54 & 1.60 & 1.70 & 1.64 & 1.49 & 1.45 & 1.43 & 1.42 & 1.50 & 1.50 \\
\hline Gross federal funds sold and reverse RPs & .38 & .36 & .28 & .17 & .14 & .14 & .21 & .20 & .19 & .22 \\
\hline Other $\ldots \ldots \ldots \ldots \ldots \ldots \ldots \ldots \ldots \ldots \ldots \ldots$ & .25 & .20 & .15 & .08 & .06 & .06 & .07 & .06 & .06 & .05 \\
\hline Gross interest expense & 5.84 & 5.54 & 4.68 & 3.16 & 2.46 & 2.65 & 3.46 & 3.40 & 3.47 & 3.45 \\
\hline Deposits ........... & 4.69 & 4.58 & 4.03 & 2.75 & 2.07 & 2.01 & 2.56 & 2.57 & 2.70 & 2.72 \\
\hline Gross federal funds purchased and RPs & .83 & .67 & .42 & .25 & .22 & .35 & .46 & .43 & .37 & .32 \\
\hline Other $\ldots \ldots \ldots \ldots \ldots \ldots \ldots \ldots \ldots \ldots \ldots \ldots \ldots$ & .31 & .29 & .23 & .17 & .17 & .29 & .44 & .40 & .40 & .41 \\
\hline Net interest income .... & 3.84 & 3.83 & 3.96 & 4.19 & 4.28 & 4.25 & 4.23 & 4.27 & 4.29 & 4.19 \\
\hline Taxable equivalent & 4.02 & 3.97 & 4.08 & 4.30 & 4.38 & 4.34 & 4.31 & 4.35 & 4.37 & 4.28 \\
\hline Loss provisioning $^{5} \ldots$ & .75 & 1.12 & 1.07 & .77 & .47 & .33 & .43 & .50 & .56 & .48 \\
\hline Noninterest income .......... & 1.38 & 1.50 & 1.65 & 1.69 & 1.84 & 1.86 & 1.84 & 1.88 & 2.08 & 2.25 \\
\hline Service charges on deposits .... & .36 & .37 & .40 & .44 & .45 & .42 & .42 & .42 & .40 & .39 \\
\hline Income from fiduciary activities $\ldots \ldots \ldots \ldots$ & .25 & .26 & .27 & .28 & .29 & .28 & .27 & .28 & .32 & .34 \\
\hline Trading income $\ldots \ldots \ldots \ldots \ldots \ldots \ldots \ldots$ & .04 & .02 & .04 & .02 & .03 & .02 & .03 & .02 & .01 & .01 \\
\hline Interest rate exposures $\ldots \ldots \ldots \ldots \ldots$ & n.a. & n.a. & n.a. & n.a. & n.a. & n.a. & n.a. & .01 & .01 & .01 \\
\hline Foreign exchange exposures $\ldots \ldots \ldots \ldots \ldots$ & n.a. & n.a. & n.a. & n.a. & n.a. & n.a. & n.a. & .01 & $*$ & * \\
\hline Equity, commodity, and other exposures ... & n.a. & n.a. & n.a. & n.a. & n.a. & n.a. & n.a. & * & $*$ & $*$ \\
\hline 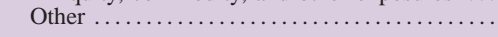 & .74 & .84 & .95 & .95 & 1.08 & 1.14 & 1.12 & 1.16 & 1.34 & 1.51 \\
\hline Noninterest expense $\ldots \ldots \ldots \ldots \ldots \ldots \ldots$ & 3.45 & 3.50 & 3.77 & 3.87 & 3.92 & 3.78 & 3.68 & 3.68 & 3.73 & 3.87 \\
\hline Salaries, wages, and employee benefits & 1.48 & 1.47 & 1.48 & 1.51 & 1.51 & 1.49 & 1.44 & 1.44 & 1.51 & 1.57 \\
\hline Expenses of premises and fixed assets & .49 & .49 & .49 & .49 & .48 & .46 & .45 & .45 & .46 & .47 \\
\hline Other $\ldots \ldots \ldots \ldots \ldots \ldots \ldots \ldots \ldots \ldots$ & 1.49 & 1.55 & 1.80 & 1.87 & 1.93 & 1.83 & 1.79 & 1.80 & 1.76 & 1.83 \\
\hline Net noninterest expense $\ldots \ldots \ldots \ldots \ldots \ldots \ldots$ & 2.07 & 2.01 & 2.12 & 2.18 & 2.08 & 1.92 & 1.84 & 1.81 & 1.65 & 1.61 \\
\hline Realized gains on investment account securities & .01 & .01 & .09 & .10 & .06 & -.05 & -.01 & .02 & .02 & .04 \\
\hline Income before taxes and extraordinary items ... & 1.02 & .72 & .86 & 1.35 & 1.78 & 1.96 & 1.96 & 1.98 & 2.10 & 2.14 \\
\hline Taxes $\ldots \ldots \ldots \ldots \ldots$ & .32 & .21 & .29 & .44 & .61 & .67 & .67 & .69 & .73 & .73 \\
\hline Extraordinary items $\ldots \ldots \ldots \ldots \ldots \ldots \ldots$ & $*$ & $*$ & -.07 & $*$ & .04 & * & $*$ & $*$ & $*$ & .06 \\
\hline Net income (return on assets) & .71 & .51 & .49 & .91 & 1.22 & 1.29 & 1.28 & 1.29 & 1.37 & 1.47 \\
\hline Cash dividends declared ... & .48 & .53 & .33 & .49 & .79 & .81 & .87 & 1.04 & 1.10 & 1.02 \\
\hline Retained income .......... & .23 & -.02 & .16 & .42 & .43 & .48 & .41 & .25 & .28 & .45 \\
\hline Mемо: Return on equity .. & 10.54 & 7.37 & 6.93 & 12.13 & 14.93 & 15.40 & 14.82 & 14.45 & 14.93 & 15.53 \\
\hline
\end{tabular}

* In absolute value, less than 0.005 percent.

Definitions. n.a. Not available. MMDA Money market deposit account. RP Repurchase agreement. CD Certificate of deposit.

1. Includes the allowance for loan and lease losses and the allocated transfer risk reserve.

2. Before 1994, the netted value of off-balance-sheet items appeared in "trading account securities"

if a gain and "other non-interest-bearing liabilities" if a loss.

3. When possible, based on the average of quarterly balance sheet data reported on schedule RC-K of the quarterly Call Reports.

3. Includes provisions for loan and lease losses and for allocated transfer risk.

4. Before 1997, data for large time open accounts are included in small-denomination time deposits.

5. Includes provisions for loan and lease losses and for allocated transfer risk. 
A.2. Portfolio composition, interest rates, and income and expense, all U.S. banks, 1989-98

E. Banks not ranked among the 1,000 largest by assets

\begin{tabular}{|c|c|c|c|c|c|c|c|c|c|c|}
\hline Item & 1989 & 1990 & 1991 & 1992 & 1993 & 1994 & 1995 & 1996 & 1997 & 1998 \\
\hline & \multicolumn{10}{|c|}{ Balance sheet items as a percentage of average net consolidated assets } \\
\hline Interest-earning assets . & 90.90 & 91.06 & 91.25 & 91.39 & 91.65 & 91.72 & 91.70 & 91.64 & 91.65 & 91.88 \\
\hline Loans and leases, net & 54.84 & 54.74 & 54.05 & 53.03 & 52.94 & 54.64 & 56.62 & 57.37 & 58.77 & 59.13 \\
\hline Commercial and industrial & 12.10 & 11.53 & 10.60 & 9.74 & 9.24 & 9.31 & 9.65 & 9.98 & 10.15 & 10.33 \\
\hline U.S. addressees ......... & 12.07 & 11.49 & 10.56 & 9.69 & 9.20 & 9.26 & 9.59 & 9.90 & 10.07 & 10.25 \\
\hline Foreign addressees ... & .03 & .04 & .04 & .04 & .04 & .05 & .06 & .07 & .08 & .08 \\
\hline Consumer ........... & 11.46 & 11.20 & 10.44 & 9.69 & 9.18 & 9.37 & 9.57 & 9.41 & 9.06 & 8.48 \\
\hline Credit card .......... & .93 & 1.00 & 1.02 & 1.00 & .93 & .96 & 1.04 & 1.03 & .91 & .71 \\
\hline Installment and other & 10.53 & 10.20 & 9.42 & 8.69 & 8.25 & 8.41 & 8.53 & 8.38 & 8.15 & 7.77 \\
\hline Real estate ........... & 27.36 & 28.35 & 29.34 & 30.15 & 31.09 & 32.19 & 33.54 & 34.10 & 35.51 & 36.04 \\
\hline In domestic offices & 27.36 & 28.35 & 29.33 & 30.15 & 31.08 & 32.19 & 33.54 & 34.09 & 35.50 & 36.04 \\
\hline Construction and land development & 2.29 & 2.37 & 2.18 & 1.98 & 1.93 & 2.14 & 2.38 & 2.61 & 2.82 & 3.01 \\
\hline Farmland $\ldots \ldots \ldots \ldots \ldots \ldots \ldots \ldots$ & 1.82 & 1.86 & 1.93 & 2.06 & 2.20 & 2.34 & 2.48 & 2.55 & 2.68 & 2.83 \\
\hline One- to four-family residential ... & 14.81 & 15.37 & 16.00 & 16.44 & 16.81 & 16.95 & 17.45 & 17.47 & 18.15 & 18.05 \\
\hline Home equity $\ldots \ldots \ldots \ldots \ldots$ & .94 & 1.16 & 1.29 & 1.34 & 1.27 & 1.21 & 1.20 & 1.19 & 1.24 & 1.21 \\
\hline Other $\ldots \ldots \ldots \ldots$ & 13.86 & 14.21 & 14.71 & 15.10 & 15.54 & 15.73 & 16.25 & 16.28 & 16.91 & 16.84 \\
\hline Multifamily residential & .62 & .66 & .71 & .77 & .84 & .93 & .95 & .92 & .95 & .93 \\
\hline Nonfarm nonresidential & 7.82 & 8.09 & 8.50 & 8.90 & 9.30 & 9.83 & 10.27 & 10.54 & 10.91 & 11.21 \\
\hline In foreign offices ........ & * & $*$ & $*$ & $*$ & $*$ & * & $*$ & * & * & $*$ \\
\hline Depository institutions & .26 & .23 & .20 & .13 & .12 & .13 & .16 & .17 & .17 & .12 \\
\hline Foreign governments .. & .01 & .01 & .01 & .01 & .02 & .01 & $*$ & $*$ & $*$ & $*$ \\
\hline Agricultural production & 3.28 & 3.30 & 3.48 & 3.55 & 3.58 & 3.89 & 3.95 & 3.93 & 4.05 & 4.27 \\
\hline Other loans .............. & 1.67 & 1.41 & 1.24 & .99 & .87 & .81 & .76 & .72 & .70 & .69 \\
\hline Lease-financing receivables .... & .19 & .18 & .17 & .17 & .18 & .20 & .22 & .23 & .25 & .25 \\
\hline LESS: Unearned income on loans & -60 & -.58 & -.51 & -.43 & -.36 & -.31 & -.30 & -.27 & -.24 & -.20 \\
\hline LEss: Loss reserves ${ }^{1} \ldots \ldots \ldots \ldots$ & -.88 & -.89 & -.93 & -.96 & -.97 & -.95 & -.93 & -.90 & -.88 & -.86 \\
\hline Securities ............ & 27.92 & 28.38 & 29.99 & 32.10 & 33.06 & 32.90 & 30.50 & 29.53 & 28.21 & 26.67 \\
\hline Investment account & 27.85 & 28.28 & 29.94 & 32.04 & 33.00 & 32.86 & 30.46 & 29.50 & 28.18 & 26.65 \\
\hline Debt .............. & 27.45 & 27.92 & 29.56 & 31.60 & 32.55 & 32.42 & 30.01 & 29.01 & 27.65 & 26.11 \\
\hline U.S. Treasury $\ldots \ldots \ldots \ldots$ & 8.84 & 8.77 & 9.24 & 10.25 & 10.48 & 10.81 & 9.19 & 7.85 & 6.70 & 5.05 \\
\hline \multicolumn{11}{|l|}{ U.S. government agency and } \\
\hline corporation obligations $\ldots \ldots \ldots$ & 11.37 & 12.43 & 13.82 & 15.04 & 15.80 & 15.35 & 15.12 & 15.67 & 15.55 & 15.42 \\
\hline Government-backed mortgage pools & 3.76 & 4.58 & 5.59 & 5.52 & 5.38 & 4.81 & 4.19 & 4.21 & 4.00 & 3.90 \\
\hline Collateralized mortgage obligations & n.a. & .90 & 1.56 & 2.66 & 3.33 & 3.11 & 2.75 & 2.46 & 2.19 & 2.01 \\
\hline Other $\ldots \ldots \ldots \ldots \ldots \ldots \ldots$ & 7.61 & 6.93 & 6.68 & 6.85 & 7.09 & 7.43 & 8.18 & 9.00 & 9.37 & 9.51 \\
\hline 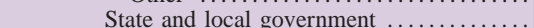 & 4.94 & 4.56 & 4.26 & 4.29 & 4.70 & 5.01 & 4.69 & 4.62 & 4.59 & 4.80 \\
\hline Private mortgage-backed securities & n.a. & n.a. & $\begin{array}{r}7.20 \\
.89\end{array}$ & .77 & .47 & .27 & .20 & $\begin{array}{r}7.02 \\
.18\end{array}$ & .19 & .16 \\
\hline Other $\ldots \ldots \ldots \ldots \ldots \ldots \ldots \ldots$ & 2.29 & 2.15 & 1.34 & 1.26 & 1.10 & .98 & .81 & .68 & .61 & .68 \\
\hline Equity .. & .40 & .36 & .38 & .44 & .45 & .44 & .45 & .49 & .52 & .54 \\
\hline Trading account $\ldots \ldots \ldots \ldots \ldots \ldots \ldots$ & .07 & .10 & .06 & .05 & .07 & .04 & .03 & .03 & .03 & .02 \\
\hline Gross federal funds sold and reverse RPs & 5.74 & 6.13 & 5.64 & 5.10 & 4.69 & 3.42 & 3.92 & 4.05 & 3.96 & 5.12 \\
\hline Interest-bearing balances at depositories .. & 2.40 & 1.81 & 1.57 & 1.16 & .97 & .77 & .67 & .69 & .71 & .96 \\
\hline 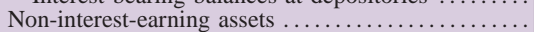 & 9.10 & 8.94 & 8.75 & 8.61 & 8.35 & 8.28 & 8.30 & 8.36 & 8.35 & 8.12 \\
\hline Revaluation gains on off-balance-sheet items $^{2}$ & n.a. & n.a. & n.a. & n.a. & n.a. & $*$ & $*$ & $*$ & $*$ & $*$ \\
\hline 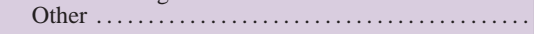 & 9.10 & 8.94 & 8.75 & 8.61 & 8.35 & 8.28 & 8.30 & 8.36 & 8.35 & 8.12 \\
\hline Liabilities..$\ldots \ldots \ldots \ldots \ldots$ & 91.44 & 91.40 & 91.37 & 91.07 & 90.63 & 90.43 & 90.03 & 89.81 & 89.62 & 89.53 \\
\hline Interest-bearing liabilities & 77.13 & 77.83 & 78.39 & 77.83 & 76.89 & 76.19 & 75.74 & 75.58 & 75.47 & 75.35 \\
\hline Deposits ............. & 75.00 & 75.79 & 76.40 & 75.75 & 74.53 & 73.14 & 72.68 & 72.47 & 71.99 & 71.76 \\
\hline In foreign offices & .06 & .07 & .08 & .07 & .08 & .09 & .11 & .10 & .09 & .07 \\
\hline In domestic offices ........ & 74.93 & 75.72 & 76.33 & 75.68 & 74.45 & 73.05 & 72.56 & 72.36 & 71.90 & 71.70 \\
\hline Other checkable deposits ... & 10.38 & 10.45 & 10.99 & 12.33 & 13.15 & 13.31 & 12.37 & 11.75 & 11.37 & 11.17 \\
\hline Savings (including MMDAs) $\ldots \ldots$ & 19.51 & 18.73 & 19.35 & 22.10 & 23.55 & 23.23 & 20.40 & 19.56 & 18.98 & 19.01 \\
\hline Small-denomination time deposits .. & 33.66 & 35.37 & 35.88 & 32.85 & 30.10 & 28.83 & 30.91 & 31.28 & 31.05 & 30.42 \\
\hline Large-denomination time deposits & 11.38 & 11.17 & 10.11 & 8.40 & 7.65 & 7.68 & 8.88 & 9.77 & 10.49 & 11.10 \\
\hline Gross federal funds purchased and RPs ... & 1.35 & 1.36 & 1.31 & 1.36 & 1.44 & 1.89 & 1.78 & 1.70 & 1.68 & 1.50 \\
\hline Other $\ldots \ldots \ldots \ldots \ldots \ldots \ldots \ldots \ldots \ldots \ldots \ldots$ & .78 & .67 & .68 & .72 & .91 & 1.16 & 1.28 & 1.41 & 1.80 & 2.09 \\
\hline Non-interest-bearing liabilities $\ldots \ldots \ldots \ldots \ldots \ldots$ & 14.31 & 13.57 & 12.98 & 13.24 & 13.75 & 14.25 & 14.29 & 14.23 & 14.15 & 14.18 \\
\hline Demand deposits in domestic offices ........... & 13.09 & 12.37 & 11.84 & 12.23 & 12.82 & 13.34 & 13.22 & 13.13 & 13.09 & 13.08 \\
\hline Revaluation losses on off-balance-sheet items ${ }^{2}$ & n.a. & n.a. & n.a. & n.a. & n.a. & * & $*$ & * & * & $*$ \\
\hline 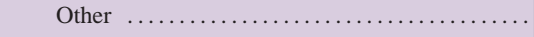 & 1.22 & 1.21 & 1.14 & 1.01 & .93 & .90 & 1.07 & 1.10 & 1.06 & 1.10 \\
\hline Capital account & 8.56 & 8.60 & 8.63 & 8.93 & 9.37 & 9.57 & 9.97 & 10.19 & 10.38 & 10.47 \\
\hline \multicolumn{11}{|l|}{ Мемо } \\
\hline Commercial real estate loans & n.a. & n.a. & 11.74 & 11.84 & 12.22 & 13.02 & 13.71 & 14.18 & 14.78 & 15.26 \\
\hline Other real estate owned ..... & .63 & .61 & .66 & .65 & .52 & .35 & .25 & .20 & .16 & .13 \\
\hline Managed liabilities ............. & 13.59 & 13.29 & 12.19 & 10.56 & 10.10 & 10.83 & 12.08 & 13.00 & 14.08 & 14.77 \\
\hline $\begin{array}{l}\text { Average net consolidated assets } \\
\text { (billions of dollars) }\end{array}$ & 662 & 681 & 694 & 697 & 688 & 679 & 666 & 661 & 648 & 644 \\
\hline
\end{tabular}




\section{A.2.-Continued}

E. Banks not ranked among the 1,000 largest by assets

\begin{tabular}{|c|c|c|c|c|c|c|c|c|c|c|}
\hline Item & 1989 & 1990 & 1991 & 1992 & 1993 & 1994 & 1995 & 1996 & 1997 & 1998 \\
\hline & \multicolumn{10}{|c|}{ Effective interest rate (percent) ${ }^{3}$} \\
\hline \multicolumn{11}{|l|}{ Rates earned } \\
\hline Interest-earning assets . & 10.50 & 10.31 & 9.64 & 8.43 & 7.62 & 7.57 & 8.41 & 8.35 & 8.50 & 8.33 \\
\hline Taxable equivalent .. & 10.72 & 10.52 & 9.82 & 8.59 & 7.78 & 7.72 & 8.56 & 8.49 & 8.63 & 8.50 \\
\hline Loans and leases, gross ... & 11.76 & 11.60 & 11.02 & 9.83 & 9.14 & 9.00 & 9.85 & 9.74 & 9.81 & 9.70 \\
\hline Net of loss provisions & 10.87 & 10.65 & 10.08 & 9.05 & 8.63 & 8.65 & 9.42 & 9.31 & 9.36 & 9.22 \\
\hline Securities ............... & 8.37 & 8.42 & 8.04 & 6.99 & 5.92 & 5.61 & 6.09 & 6.10 & 6.25 & 5.98 \\
\hline Taxable equivalent & 9.01 & 8.99 & 8.53 & 7.40 & 6.33 & 5.99 & 6.49 & 6.52 & 6.65 & 6.47 \\
\hline Investment account $\ldots \ldots \ldots \ldots \ldots$ & 8.36 & 8.41 & 8.04 & 6.99 & 5.92 & 5.61 & 6.09 & 6.10 & 6.25 & 5.98 \\
\hline U.S. government and other debt & 8.53 & 8.59 & 8.20 & 7.06 & 5.91 & 5.59 & 6.17 & 6.23 & 6.43 & 6.16 \\
\hline 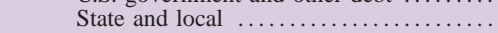 & 7.57 & 7.46 & 7.17 & 6.70 & 6.09 & 5.69 & 5.64 & 5.44 & 5.32 & 5.14 \\
\hline Equity ........ & 8.12 & 8.30 & 7.14 & 5.64 & 5.16 & 5.52 & 6.26 & 6.06 & 6.40 & 6.11 \\
\hline Trading account $\ldots \ldots \ldots \ldots \ldots \ldots \ldots$ & 14.84 & 12.13 & 8.41 & 7.14 & 4.83 & 6.03 & 6.12 & 6.48 & 6.60 & 6.45 \\
\hline Gross federal funds sold and reverse RPs .... & 9.25 & 8.12 & 5.66 & 3.51 & 2.95 & 4.08 & 5.95 & 5.39 & 5.51 & 5.36 \\
\hline Interest-bearing balances at depositories ....... & 9.11 & 8.55 & 7.35 & 5.59 & 4.53 & 4.64 & 5.91 & 6.10 & 5.70 & 5.68 \\
\hline \multicolumn{11}{|l|}{ Rates paid } \\
\hline Interest-bearing liabilities . & 7.16 & 7.02 & 6.17 & 4.44 & 3.54 & 3.49 & 4.47 & 4.49 & 4.61 & 4.61 \\
\hline Interest-bearing deposits & 7.10 & 6.96 & 6.15 & 4.44 & 3.53 & 3.44 & 4.39 & 4.44 & 4.54 & 4.53 \\
\hline In foreign offices $\ldots .$. & 9.35 & 7.57 & 5.95 & 3.97 & 2.91 & 3.92 & 5.73 & 11.43 & 4.77 & 5.08 \\
\hline In domestic offices ........ & 7.10 & 6.96 & 6.15 & 4.44 & 3.53 & 3.44 & 4.39 & 4.43 & 4.54 & 4.53 \\
\hline Other checkable deposits & 5.09 & 5.02 & 4.61 & 3.14 & 2.42 & 2.29 & 2.50 & 2.41 & 2.46 & 2.45 \\
\hline Savings (including MMDAs) ...... & 5.82 & 5.73 & 5.18 & 3.62 & 2.91 & 2.83 & 3.32 & 3.24 & 3.37 & 3.39 \\
\hline Large-denomination time deposits 4 & 8.35 & 7.92 & 6.72 & 4.90 & 3.96 & 4.12 & 5.55 & 5.49 & 5.53 & 5.54 \\
\hline Small-denomination time deposits ${ }^{4}$ & 8.03 & 7.88 & 6.98 & 5.36 & 4.39 & 4.28 & 5.51 & 5.59 & 5.67 & 5.64 \\
\hline Gross federal funds purchased and RPs ...... & 8.52 & 8.03 & 5.72 & 3.74 & 3.17 & 4.12 & 5.62 & 5.10 & 5.23 & 5.05 \\
\hline \multirow[t]{2}{*}{ Other interest-bearing liabilities...$\ldots \ldots \ldots$} & 8.31 & 7.84 & 7.06 & 5.01 & 4.64 & 4.98 & 6.87 & 5.84 & 6.15 & 6.44 \\
\hline & \multicolumn{10}{|c|}{ Income and expense as a percentage of average net consolidated assets } \\
\hline Gross interest income . & 9.65 & 9.51 & 8.91 & 7.79 & 7.05 & 7.01 & 7.80 & 7.75 & 7.89 & 7.74 \\
\hline Taxable equivalent & 9.85 & 9.68 & 9.06 & 7.94 & 7.19 & 7.15 & 7.93 & 7.87 & 8.01 & 7.86 \\
\hline Loans .............. & 6.53 & 6.44 & 6.04 & 5.30 & 4.91 & 4.98 & 5.66 & 5.67 & 5.85 & 5.80 \\
\hline Securities $\ldots \ldots \ldots \ldots \ldots \ldots \ldots \ldots \ldots$ & 2.33 & 2.38 & 2.41 & 2.24 & 1.95 & 1.84 & 1.86 & 1.80 & 1.76 & 1.59 \\
\hline Gross federal funds sold and reverse RPs & .57 & .53 & .34 & .18 & .14 & .15 & .25 & .24 & .24 & .29 \\
\hline 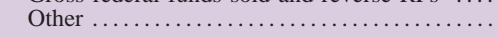 & .23 & .17 & .12 & .07 & .05 & .04 & .04 & .04 & .04 & .06 \\
\hline Gross interest expense & 5.50 & 5.44 & 4.82 & 3.45 & 2.72 & 2.65 & 3.38 & 3.38 & 3.47 & 3.46 \\
\hline Deposits ................. & 5.32 & 5.28 & 4.70 & 3.36 & 2.63 & 2.52 & 3.19 & 3.22 & 3.28 & 3.25 \\
\hline Gross federal funds purchased and RPs & .12 & .11 & .07 & .05 & .04 & .07 & .10 & .08 & .08 & .07 \\
\hline 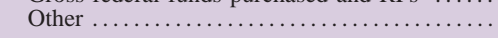 & .06 & .05 & .05 & .04 & .04 & .06 & .09 & .08 & .11 & .13 \\
\hline Net interest income .... & 4.15 & 4.07 & 4.09 & 4.34 & 4.33 & 4.36 & 4.42 & 4.37 & 4.41 & 4.28 \\
\hline Taxable equivalent & 4.35 & 4.24 & 4.24 & 4.49 & 4.48 & 4.50 & 4.55 & 4.49 & 4.54 & 4.40 \\
\hline Loss provisioning $^{5} \ldots$. & .50 & .53 & .51 & .42 & .27 & .19 & .25 & .25 & .27 & .29 \\
\hline Noninterest income ........... & 1.00 & 1.01 & 1.07 & 1.16 & 1.25 & 1.30 & 1.38 & 1.42 & 1.44 & 1.53 \\
\hline Service charges on deposits .... & .41 & .42 & .44 & .45 & .45 & .44 & .44 & .44 & .44 & .42 \\
\hline Income from fiduciary activities & .14 & .14 & .14 & .16 & .16 & .17 & .22 & .20 & .20 & .23 \\
\hline Trading income $\ldots \ldots \ldots \ldots \ldots$ & .01 & .01 & .01 & .01 & .01 & * & .01 & $*$ & $*$ & $*$ \\
\hline Interest rate exposures $\ldots \ldots \ldots \ldots \ldots$ & n.a. & n.a. & n.a. & n.a. & n.a. & n.a. & n.a. & $*$ & * & $*$ \\
\hline Foreign exchange exposures...$\ldots \ldots \ldots$ & n.a. & n.a. & n.a. & n.a. & n.a. & n.a. & n.a. & $*$ & $*$ & * \\
\hline Equity, commodity, and other exposures . & n.a. & n.a. & n.a. & n.a. & n.a. & n.a. & n.a. & $*$ & $*$ & * \\
\hline Other...$\ldots \ldots \ldots \ldots \ldots \ldots \ldots \ldots \ldots$ & .44 & .44 & .49 & .55 & .64 & .69 & .71 & .78 & .79 & .88 \\
\hline Noninterest expense $\ldots \ldots \ldots \ldots \ldots \ldots \ldots$ & 3.49 & 3.49 & 3.59 & 3.67 & 3.74 & 3.78 & 3.81 & 3.70 & 3.70 & 3.74 \\
\hline Salaries, wages, and employee benefits ... & 1.65 & 1.64 & 1.64 & 1.69 & 1.72 & 1.75 & 1.80 & 1.77 & 1.80 & 1.82 \\
\hline Expenses of premises and fixed assets $\ldots \ldots \ldots$ & .51 & .49 & .49 & .49 & .48 & .49 & .50 & .49 & .49 & .49 \\
\hline 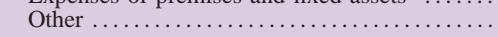 & 1.33 & 1.36 & 1.46 & 1.49 & 1.53 & 1.55 & 1.51 & 1.44 & 1.41 & 1.43 \\
\hline Net noninterest expense $\quad \ldots \ldots \ldots \ldots \ldots \ldots \ldots$ & 2.49 & 2.48 & 2.52 & 2.51 & 2.48 & 2.48 & 2.43 & 2.28 & 2.27 & 2.21 \\
\hline Realized gains on investment account securities & .01 & $*$ & .06 & .09 & .07 & -0.03 & $*$ & .01 & .01 & .02 \\
\hline Income before taxes and extraordinary items .... & 1.17 & 1.06 & 1.11 & 1.50 & 1.64 & 1.66 & 1.75 & 1.85 & 1.89 & 1.80 \\
\hline 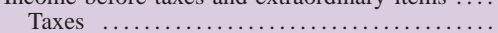 & .37 & .34 & .35 & .47 & .51 & .51 & .55 & .59 & .59 & .54 \\
\hline Extraordinary items $\ldots . .$. & .02 & .02 & .19 & .02 & .05 & $*$ & $*$ & $*$ & $*$ & $*$ \\
\hline Net income (return on assets) & .83 & .74 & .95 & 1.04 & 1.19 & 1.15 & 1.20 & 1.26 & 1.30 & 1.26 \\
\hline Cash dividends declared ... & .52 & .49 & .89 & .50 & .56 & .57 & .62 & .64 & .73 & .83 \\
\hline Retained income ........ & .30 & .25 & .06 & .54 & .63 & .58 & .58 & .62 & .57 & .44 \\
\hline Мемо: Return on equity & 9.66 & 8.61 & 11.05 & 11.64 & 12.65 & 12.05 & 12.05 & 12.33 & 12.54 & 12.07 \\
\hline
\end{tabular}

* In absolute value, less than 0.005 percent.

Definitions. n.a. Not available. MMDA Money market deposit account. RP Repurchase agreement. CD Certificate of deposit.

1. Includes the allowance for loan and lease losses and the allocated transfer risk reserve.

2. Before 1994, the netted value of off-balance-sheet items appeared in "trading account securities"

if a gain and "other non-interest-bearing liabilities" if a loss.

3. When possible, based on the average of quarterly balance sheet data reported on schedule RC-K of the quarterly Call Reports.

4. Before 1997, data for large time open accounts are included in small-denomination time deposits.

5. Includes provisions for loan and lease losses and for allocated transfer risk. 